University of Montana

ScholarWorks at University of Montana

University of Montana Bulletin: Biological

Series, 1901-1910

Flathead Lake Biological Station

$1-1-1901$

\title{
Summer Birds of Flathead Lake, 1901
}

University of Montana (Missoula, Mont. : 1893-1913). Biological Station, Flathead Lake

Perley Milton Silloway

Follow this and additional works at: https://scholarworks.umt.edu/umbiologicalseries

Let us know how access to this document benefits you.

\section{Recommended Citation}

University of Montana (Missoula, Mont. : 1893-1913). Biological Station, Flathead Lake and Silloway, Perley Milton, "Summer Birds of Flathead Lake, 1901" (1901). University of Montana Bulletin: Biological Series, 1901-1910. 1.

https://scholarworks.umt.edu/umbiologicalseries/1

This Book is brought to you for free and open access by the Flathead Lake Biological Station at ScholarWorks at University of Montana. It has been accepted for inclusion in University of Montana Bulletin: Biological Series, 1901-1910 by an authorized administrator of ScholarWorks at University of Montana. For more information, please contact scholarworks@mso.umt.edu. 
BULLETIN OF THE UNIVERSITY OF MONTANA

letin No. 3

Biological Series No. 1

Summer Birds of Flathead Lake

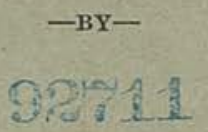

P. M. SILLOWAY,

PRINCIPAL, FERGUS COUNTY HIGH SCHOOL, AUTHOR OF SOME COMMON BIRDS.

- PROPARED AT THE UNIVERSITY OF MONTANA BIOLOGICAL STATION, UNDER DIRECTION OF

MORTON J. ELROD.

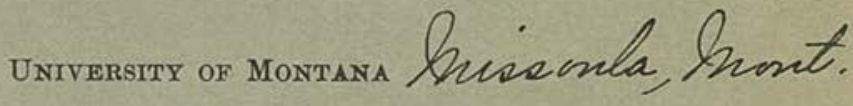
1901 

BULLETIN OF THE UNIVERSITY OF MONTANA

Bulletin No. 1

Biological Series No. 1

\section{Summer Birds of Flathead Lake}

$-\mathrm{BY}-$

P. M. SILLOWAY

PRICE

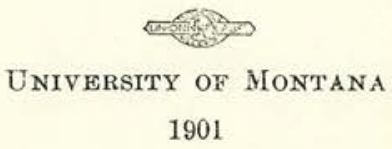





\section{Fummer $\mathfrak{B}$ irds of flatbead $\mathfrak{L a k e}$}

\section{P. M. SILLOWAY.}

Notes based upon observations made between June 14 and August 30, 1900. From June 14 to July 6, observations were made from the University of Montana Biological Station at the head of Flathead Lake as a center; from July 9 to July 18, at Sin-yale-a-min Lake, Mission Mountains; from July 19 to July $2 \%$, at McDonald Lake, Mission Mountains; from July 28 to August 3, in the region between the foot of Mt. McDonald and the foot of Flathead Lake; during the remainder of the period stated, the Biological Station was again the center of operations.

Additional observations were made in June and July, 1901, which have been recorded in the appropriate places.

Prepared under direction of the University of Montana Biological Station.

\section{SIN-YALE-A-MIN LAKE.}

Sin-yale-a-min Lake lies in a depression of the Mission Mountains at an elevation of 3900 feet. The depression is probably the result of glacial action, in which the bed of the lake was scooped out by the moving ice-mass, the trend being nearly from east to west. The western end of the depression is blocked by what seems to be a terminal moraine, through which the outlet of the lake makes its way. The lake is fed by a stream which comes dashing down a gorge on the northeast, the descent being so steep about a quarter of a mile from the lake that there is a succession of beautiful falls extending over several hundred feet. Between the lake and the falls the stream is thickly bordered by massive arbor vitae, whose numerous standing trunks and accompanying fallen growth form an almost impassable jungle. However, a trail can be followed from the lake to the falls with no great difficulty. Along this stream the cheerful chant of the winter wren can be heard, and in the leaping spray of the falls the American dipper loves to play. 
North of the lake, rising quite abruptly from the water's edge, lies the first of a series of ridges which culminate in Sin-yale-a-min Mountain, whose bald head and snow-clad shoulders can be seen very clearly from the outlet of the lake. Between the lake and the summit of Sin-yale-a-min Peak, whose altitude is approximately 9200 feet, there rises nearly three miles of wooded mountain-side, the home of Clarke's nutcracker and Richardson's grouse, with other birds of Alpine habitat. As on the north, the southern shore of the lake is the foot of a high, wooded ridge, where the Rocky Mountain jay and black-headed jay flit among the trees, and the ruffed grouse hides in the fir thickets.

Following an easy trail leading somewhat southeast from the lake, the collector passes through a wide ravine for about a mile, and reaches a small lake or pond a few acres in extent, surrounded by a woodland free from undergrowth. Here tall handsome yellow pines (pinus ponderosa) abound, in whose tops are seen occasional flocks of chirping crossbills, lisping cedar waxwings, and other inhabitants of the woods.

West of the lake there lies an extensive region of lower primeval woodland alternating with bushy hillside, through which the outlet of the lake dashes on its course to the prairie region of the Flathead Indian Reservation, all forming an ideal collecting ground, certain to repay the careful attention of the ornithologist.

\section{McDONALD LAKE.}

$\mathrm{McDonald}$ Lake is at somewhat lower elevation than Sinyale-a-min Lake, being about 3,300 feet altitude. In area it is not nearly so large, as its length measures only rather more than half that of Sin-yale-a-min, and its width about the same ratio in measurement. In our estimates we placed the length of Sin-yale-a-min at 7,000 feet, and its width at 2,200 feet. Neither is McDonald Lake as deep as Sin-yale-a-min Lake, the general depth of the former being about 70 feet while the deepest place in the latter is 250 feet.

McDonald Lake is evidently the bed of an ancient glacier, whose resistless action can be traced by fine chisellings on the sides of the jutting rocks along the lake shore. The lake is fed by a small stream which hurries down between Mt. McDonald and an adjacent mountain. Along its eastern shore the lake is overhung by a rugged, picturesque cliff, rising sheer 
two thousand feet or more, from whose crevices leap several miniature waterfalls like threads of spray. Along this impending cliff hawks and ravens rear their young on shelving crags, and the towering walls give back their harsh cries.

From the southern shore of the lake Mt. McDonald rises abruptly, stretching southward in craggy outline and snow-clad sides until it towers majestically into the clouds, the monarch of the Mission range.

Owing to the precipitous margins of McDonald Lake, collecting was attended with unusual difficulty and hardship. A specimen only a thousand feet away up the mountain side could be secured only by most arduous climbing, and even then was likely to take its departure to a more inaccessible station higher up the slope before the collector was within gunshot. Unidentified Raptores circled near the top of the cliff in perfect disregard of futile efforts to secure them. Once a Townsend's solitaire was shot, and it fell five hundred feet down the cliff, entailing a half hour's work to recover it and regain the lost ground. However, to the northward of the lake we found more accessible ground, in the heavy woods through which the outlet of the lake threaded its way, and forty-seven species was the result of our notes at this station.

\section{FROM MT. MCDONALD TO FLATHEAD LAKE.}

From Lake McDonald, imprisoned at the base of Mt. McDonald by a small moraine, the descent to the general level of the Reservation is rapid and easy, the difference being more than a thousand feet. Within a mile of the lake the variation in the avifauna is noticeable.

Between the base of the mountains and Flathead Lake, there is a treeless valley, except such dwarf and water-loving trees as are found along most of the Montana water-courses. Scattered here and there over the plain, sometimes no farther than a hundred yards apart, again separated by a mile or more, are curious formations, depressions containing pools of stagnant water, often fringed by a growth of flags or coarse grass. Most of these depressions become dry as the season advances, though the larger ones retain a supply of water until the fall or winter storms fill them and change the neighborhood into spreading marsh. These pools attract the resident and migrant shore and water birds, and offer a valuable collecting ground for the ornithologist. The surrounding plain is inhabited by 
the regular residents of the open prairies, such as the longbilled curlew, western meadow lark, and species of similar habits.

T'raversing the open prairie of the Flathead Reservation are several narrow, rapidly-coursing streams. These creeks are generally fringed by a thin growth of shrubbery, with occasional trees. At our camp on Crow Creek there were a few pines of large dimensions, in striking contrast to the dwarf willows and haw tree and other similar vegetation. Near the streams the birds occur much more numerously than upon the barren stretches at either side. There we found the catbird crooning its lullaby to its helpless younglings in the bushes; the yellow warbler and American redstart flitted among the foliage of the smaller trees; the kingfisher plied his art beside the stream; the song sparrow and the western yellow-throat frequented the low coverts along the water's edge. One of the delights of our stay at the Crow Creek camp was the wealth of avian melody which flooded our ears in the early morning hours. It is doubtful whether any other place could vie with this spot in the number of bird musicians in so limited an area.

The Biological Station of the Montana State University, which served as the center of operations, is situated near the mouth of Swan River, or Big Fork, as the stream is popularly called by neighboring residents. To the west of the Station building is the beautiful land-locked harbor, where the boats are kept. At the right of the mouth of Swan River lies an extensive low area, thickly set with tall, slender willows, sturdy aspens, stately cottonwoods, pliant birches, and trees of similar nature ,margined landward by remnants of the primeval evergreen forest. This swampy area is annually overflowed by the rising waters of the lake, and throughout the summer patches of stagnant water obstruct the passage of the adventurous collector. Among the dense willows the twilight gloom of the forest ever prevails, yet such uninviting surroundings form an ideal home for the vireos, American redstart, olive-backed and willow thrushes, yellow warbler, and other denizens of the wooded swamps. A generous portion of this region shows the effect of the rancher's axe, in the extensive growth of bushes and young evergreens that have quickly sprung up to hide the ravages of the lumberman; here are seen and heard the beautiful evening and black-headed grosbeaks, the energetic Wright's and Traill's flycatchers, the gamesome ruffed grouse, and numerous frequenters of the bush.

Up the river from the Station are bushy and wooded pas- 
tures. In the tops of the lofty pines growing there, flit merry troops of pine siskins, and animated Audubon's warblers; Louisiana tanagers flash among the foliage, and utter their charming carols; rufous and calliope hummers visit the clustering honeysuckles; Macgillivray's warblers and lazuli buntings chant among the lower shrubbery; Lewis's and other woodpeckers forage from the tree-trunks; and as the ornithologist climbs the rocky crests of the foot-hills beyond, he enters the summer home of the junco and Richardson's grouse.

Across the river from the Station, east of the mouth of the dashing current, are the Kalispell Club grounds, situated at the terminus of the Mission Mountains, and enclosed by extensive areas of the primeval forest. In these wooded regions the resounding tappings of the lordly pileated woodpeckers proclaim their presence; the milder though sturdy strokes of the three-toed woodpeckers can be heard; troops of capricious crossbills give animation to the highest foliage; the western wood pewee calls querulously from his bare perch in some lightning-slain forest monarch; here representatives of the warblers, the thrushes, the vireos, the hummingbirds, the tanagers, and indeed, of all the feathered residents of the region, find ample shelter and food, and consequently their days are spent in melody and animation.

The lake itself is worthy of separate mention, as a field for the attention of the ornithologist. Over its clear depth the American ospreys wheel and soar, ever and anon uttering their shrill whistles, and dipping into the water for their finny prey. Along its occasional sandy beaches flit the interesting sandpipers, and over its wooded shores flap the unsocial ravens. In suitable hollow tree-trunks families of golden-eyes are reared, perhaps under the shadow of the platform occupied by the osprey, a landmark for the adjacent shore. In the willows of the submerged margins noisy kingbirds rear their broods, and on projecting branches of deadened timber kingfishers sit watching for their prey.

In the vicinity of the Station there are several centers of avian activity which well repay the investigations of the bird student. Along the road leading southward from the river bridge, lies a small vale enclosing a stagnant pond called Daphnia Pond on account of the large numbers of daphnia pulex in it, among whose fringing rushes the western yellowthroat, the mountain song sparrow, the sora, red-winged blackbird, catbird, and other species find convenient retreat. To the eastward of the road and pond lie several rocky crests and 
ravines, well covered with bushy vegetation, harboring many excellent "finds" attractive to the oologist. Continuing along the road to the southward, the collector finds a beautiful pond encircled by unbroken forest. This sheet of water is known as Estey's Pond, and along its wooded borders the birds sing and thrive. In the darkened woodlands western horned owls pass the day in meditative silence; over the open area tree swallows ply to and fro in quest of hovering insects. Golden-shafted flickers tenant the decayed boles of the overflowed margins; indeed, on every hand are seen signs of avian activity, and the air is vibrant with wildwood melody.

It is scarcely necessary to add that the abundance of food throughout the region under consideration is a predominating factor in the presence and distribution of the recorded birdlife. The damp and decaying vegetation of the swampy area at the mouth of the river teems with such insect food as is most attractive to the warblers and vireos. The cleared and burnt patches abound with wild gooseberries, haws, elder, strawberries, raspberries, and the foods which are favorites of the chiefly frugivorous species. The lake shore and the hillsides are clad with wild honeysuckle, or snowberry, among which dart hummingbirds on whirring wings; and in the waste spots of bushy areas stand the giant hyssop and other seed-producing plants, a ready larder for the pine siskins, sparrows, and related Fringilline species. In few localities has Mother Nature provided so liberally for her wildwood children, and the region is accordingly populous both in number of species and in individuals. 


\section{Dological 仿otes from Jlathead Lake}

The following notes are based upon observations beginning June 14, 1900, and ending July 5, a period when many of the regular nesting birds of the region had concluded their nidification and family-rearing for the season; hence it will be understood that the notes are far from complete as a list of the birds breeding near the head of the extensive lake where the observations were made. Furthermore, the unusually early opening of the vernal season rendered the period mentioned correspondingly late for full records upon nidification; and it is but justice to the collector to state that in no case was any effort made to examine the tops of tall trees, with which the region under consideration abounds, and which were tenanted by many families of birds.

\section{WESTERN ROBIN, Merula migratoria propinqua Ridgw.}

The western robin is one of the representative breeding birds of the Flathead region. Though this species begins nidification quite early in the season, its habit of rearing more than one brood prolongs its family cares into the nesting period of many of the later breeders; consequently nests were found throughout June, containing eggs in various stages of advancement in incubation. The site is usually low, generally ranging between six and ten feet from the ground, and most frequently situated in an upright crotch. The foundation of the nest is commonly made of fine leaves or coarse grasses, upon which are constructed the mud walls characteristic of the robin and some of the other thrushes. The cavity ranges between three and four inches in diameter, and is generally less than two inches deep, being warmly bedded with soft dried grass, the upper rim of the walls being usually bare within. Four eggs, of a greenish-blue color, constitute the usual complement. Haw trees are selected most frequently for the location of the nests. 


\section{OLIVE-BACKED THRUSH, Turdus ustulatus swainsonii} (Cab.)

In number of individuals, in the frequency of its melody, and in its adaptation to the sombre surroundings of the lake region, the olive-backed thrush is the typical breeding species of the lake shore. Belonging to a more northern habitat, it has been attracted by the evident conveniences of our Montana summer resort, and great numbers of representatives of the species rear their families in the firs and other trees of the Station neighborhood. Unlike most of the recorded breeding species, however, it was only entering the period of nidification at the time of these observations, the nests found during the first few days being either recently completed and not yet occupied, or having only the beginning of the regular complements.

The opening of the nesting season for this species seems to be quite uniform in the Flathead region, for nests examined the same day showed remarkably equal progress in development with others. Most of the nests found on June 14 and 15 contained either one or two eggs, or else gave evidence of having been just completed and not yet regularly occupied. It was not until June 17 that a nest was examined containing a full complement.

The olive-backed thrush is one of the low builders. Of twenty nests, none was over ten feet from the ground; two of the twenty were placed at the foregoing limit, two were nine feet from the ground, three at eight feet, three at seven feet, four at about six feet, and the remainder three and one-fourth feet and six feet from the ground. The average site is a trifle over six and one-half feet from the ground. Distances were carefully measured with a two-foot rule.

The favored site of nests in fir trees was against the main stem, at the base of one or more horizontal branches, and at a point about three-fourths the height of the tree. In one instance the nest was placed on a horizontal branch of a fir tree about two feet from the main stem, at a place probably measuring two-thirds the length of the branch from the trunk. The nest nearest the ground was found in a triple crotch of willow growing upright in a slender sprout. Another nest was found made in an upright crotch of an oblique portion of a dead, bent sapling bare of leaves. A syringa bush growing beside a path where anglers were frequently passing was chosen in one instance, and the nest placed in an upright crotch among 
nearly perpendicular stems. In another instance the chosen site was in a larger fir, about ten feet from the ground, on a horizontal branch four feet from the trunk.

The nest generally measures from three to three and onehalf inches in height, and about four inches in diameter, outside measurements, though the structure is somewhat elliptical in outline. The cavity averages two and three-fourths inches by two and one-fourth inches, major and minor axes, and more than one and one-half inches in depth. It is founded on loose coarse grasses, the walls being made of dried grasses, green lichens, and fine weed-stems. The lining is generally fine grass, horsehair, and scanty amount of moss. Frequently a nest is found having fine bark as part of the wall materials, and occasional nests are noted without moss or lichen either in walls or lining.

The eggs of this thrush present noticeable variations in their markings. The ground color is a light greenish-blue, which in some eggs seems to be quite pale because of the lack of other marks. In other eggs the ground color is almost obscured by the number and size of the blotches of pale reddish brown. On some eggs the marks are mere specks; on others the markings are bold blotches of color. The distribution of the marks is very irregular, there being no uniformity in this respect.

The nest complement may be either four or three eggs. Of seventeen nests examined containing full sets, ten contained four eggs and the remainder contained three; hence it seems that in this region nests with four eggs are found more frequently among first sets than with only three.

The open habits in nidification of the olive-backed thrush are seemingly at variance with its shy, secretive disposition. In many instances the nests were quite unconcealed, being constructed in exposed crotches beside paths and roads, almost within reach of the passing traveler. Furthermore, the sitting bird will linger with her charge until the disturber has approached to less than arm's length. Having flitted from the nest, however, the bird will disappear in the shrubbery and remain hidden in silence, though sometimes she manifests her uneasiness by chirping mournfully from her covert.

Nests of this thrush were found in all the localities mentioned in the opening paragraphs of this paper. The favored localities, however, appeared to be the swampy area at the right of the mouth of Swan River, and the wooded, bushy lot across the road from the Station grounds. It is 
probable that extended examination of the woods around Estey's Pond, and the woods between it and the Station, would show numbers of these birds as making their habitations in the places suggested. A nest with full complement of eggs is shown in Plate III. figure 1.

\section{WILLOW THRUSH, Turdus fuscescens salicicola (Ridgw.)}

It appears that the willow thrush is not abundant in the Flathead region during the nesting season. One nest was taken, but diligent search in the vicinity of the site, and in favorable localities failed to reveal another nest, or even another specimen of this subspecies.

The nest was found on the morning of June 29. It was situated among the stems of a clump of willow saplings, and its exposed position indicated that there had been little or no instinct of concealment in the selection of the site. The sitting bird was startled from the nest, though not until the observer was within six feet of her. As there were then only three eggs in the nest, and the full complement was extremely desirable, the nest was left undisturbed. The female meanwhile, had flitted to adjacent shrubbery, and occasionally appeared momentarily to take a look at the movements of her disturber, quickly flitting back from sight.

Visiting the place on the next morning, June 30, I found the nest as I had left it on the preceding day, with only its three eggs. The female at this time was less disposed to show herself beyond the covert, but at length I was able to secure her for positive identification.

The nest was built upon the ground, being exposed on all sides for its full height, which was three and one-half inches in situ. It was founded on coarse grass stems, which also formed an external wall for most of its height. The main walls are constructed of strips of fibrous bark, weed-stems, and portions of delicate dried leaves. The fabric is lined with soft bark and fine grasses, all of a dark brownish color. The rim cavity is elliptical, its axes being two and three-fourths inches and two and three-eighths inches. The cavity is two inches deep. The three eggs were far advanced in incubation. One of the eggs is greenish blue, unmarked; the others have faint specks of pale brownish color, barely definable, upon the greenish blue ground.

The nest of the willow thrush was taken in the bushy re- 
gion of the swampy area at the right of Swan River. The location seems ideal for this swamp-loving songster to be found commonly, and it is likely that other nests were in the field of examination, but were overlooked because of the extensive area and the limited time of the observer.

\section{CATBIRD, Galeoscoptes carolinensis (Linn.)}

Though not abundant, the catbird is regularly seen and heard in the Flathead region in the vicinity of the Station. Several pairs inhabited the shrubbery about Daphnia Pond along the road leading southward from Swan River bridge, as well as the bushy woods about the Kalispell Club grounds, nests being noted in both these localities. On July 2, a nest of the catbird was found on the Club grounds. It contained four fresh eggs. Owing to the extensive distribution of this songster and its well-known/ characteristics, no notes were made regarding it beyond its presence as a summer resident.

\section{AMERICAN REDSTART, Setophaga ruticilla (Linn.)}

The American redstart was noted in abundance as a resident of the swampy area lat the right of the mouth of Swan River. So suitably adapted to the needs of this lively warbler is the willow bottom mentioned, that there the redstart appeared to be the most common warbler. Its ringing song might be heard throughout the long spring days, and the flash of its red and yellow might be seen as it fluttered here and there in quest of its insect fare. Wherever willow or haw thickets were found the redstart was certain to manifest its presence by its cheerful ditty or its restless movements among the vegetation in plying its vocation as a fly-catching warbler.

The first nest noted was taken on June 28. The nest complement was four eggs, far advanced in incubation. On that date, four other nests of this warbler were examined, all containing young birds recently hatched. It is likely that first sets of eggs of the redstart are deposited soon after the middle of June. However, on June 30 a nest was found containing four eggs, rosy fresh. Young birds from the nest had meanwhile been seen, and it is more than likely that these fresh eggs were second attempts at nidification. Furthermore, a 
nest was examined on July 3, whose complement was two eggs somewhat advanced in incubation, a fact indicative of a second laying at least.

All the nests of the American redstart examined by the writer in the Flathead region were placed in upright crotches formed by very small twigs branching from the main stem. The sites varied between eight and twenty feet from the ground, and were uniformly in the slender willows.

An illustration of a typical nest is given, Plate IV., Fig. ?. It is a neat, closely-woven structure, made principally of soft vegetable fibers, fine stems and rootlets, downy feathers, and bits of delicate leaves, thatched with fragments of gossamer. It stands two inches in height, with an external diameter of two and three-eighths inches. The cavity is one and fiveeighths inches in diameter, and one and three-eighths inches deep.

The usual nest complement seems to be four eggs; however, a nest was mentioned containing only two eggs, well incubated. The eggs are quite variable in amount of markings. The ground color is white, upon which the markings of reddish brown are found in irregular specks and blotches.

\section{MACGILLIVRAY'S WARBLER, Geothlypis macgillivayi (Aud.)}

Like the willow thrush, Macgillivray's warbler appeared to be less common than might be imagined from the suitable environments. Only one nest was noted; however, as this nest complement was so far advanced in incubation that only one of the eggs was saved for a specimen, it is likely that the lateress of the season precluded the finding of other nests of this elegant ground warbler. Favorable localities in the neighborhood were searched repeatedly without results as desired.

The nest mentioned was found in a grass tuft beside a trail made by anglers in passing up and down Swan River. It was noted on June 14, the day of the writer's arrival at the Station. The female flitted from the nest to adjacent shrubbery, acting quite indifferent regarding observation of her movements. As there was no means at hand of securing her, she was allowed to return to her nest for further ob- 
servation. When the nest was approached later in the day, however, she slipped away among neighboring stems, and gave no opportunity of securing her. She succeeded in repeating the trick several times the next day, but was finally taken for identification.

The nest was placed in a tuft of grass growing among fallen branches and sprouts. It was about eight inches from the ground, probably having been raised by the growth of the grass after the construction of the nest, as frequently happens to nests of the yellowthroat and other birds that nestle in the grass tufts. The outer wall of the nest was made of long stems of dried grass; the inner of fine rootlets and horsehair. The cavity was two and one-fourth inches in diameter, and one and seven-eighths inches in depth. There were five eggs, far advanced in incubation. The ground color of the eggs is white with a faint creamy tinge. The markings are specks and blotches of dark brown, the heavier marks being generally arranged around the larger end. In situation and construction of nest, and in the appearance of the eggs, the home of Macgillivray's warbler is much like that of the yellowthroats, of whom the former is a congener.

Like the other ground warblers, the warbler under consideration spends most of its time among the shrubbery, and in its movements it is much shyer than the western yellowthroat. In the nuptial season, however, the male frequently takes a favorite position in the summit of one of the less lofty trees of the neighborhood, and there utters at frequent intervals a pretty though short and unvaried ditty, likely to be interrupted by the approach of any meddlesome ornithologist, as the performer then generally flits to a less prominent place of recital.

\section{AUDUBON'S WARBLER, Dendroica auduboni (Towns.)}

Away from the willow swamps, in the coniferous trees of the higher woods, Audubon's warbler is the most abundant representative of its family in the Flathead region. Among the firs, with pine siskins chattering in the lofty summits, Audubon's warbler flits in the middle and lower stories, chanting its joyous measures, sporting with its fellows, or attending to the cares of its family ensconced in a tuft of the fir branch. Upon our arrival at the Station, this warbler was quite noticeable in the animated life among the higher trees, and our first 
day's collection included several males of this beautiful species. At that early date for warbler nidification, a pair was observe diligently caring for the wants of their young in a nest in a large pine, far out toward the extremity of a long horizontal branch; and as late as July 2 a nest was found containing young birds recently hatched.

The finding of the first nest with eggs of this interesting warbler was an event which I recall with pleasure. Like many good finds of the collector, it was by the rarest fortune that this one habitation of Dendroica auduboni was taken, for though the swampy area was thoroughly searched, no other nest of this species rewarded our eager quest; however, another nest with young birds was found in a different locality several days later.

On June 27, while hunting for soras in a small grassy opening in the swamp, my attention was attracted by the peculiar chirping of a pair of western evening grosbeaks flying overhead. Noticing that they flew rapidly in one direction, I thought perhaps there was a nest in their line of flight, or that their objective point might be their nesting place, a desideratum far too valuable to be neglected. Entering the thick growth of slender willows enclosing the grassy slough, I had proceeded but a few steps when I espied a small grayish mass up in a crotch of one of the willow stems. Without being certain that it was a nest, I shook the stem, when a sitting bird flew downward obliquely and was rapidly making away among the bases of surrounding trees as I caught her by a fortunate shot. The prize proved to be a female of Dendroica auduboni, and I was not long in ascending to the nest and securing it, with its five fresh eggs. It is needless to add that I was not rewarded so happily in my quest for the nest of the grosbeaks.

The nest under consideration was eighteen feet from the ground, in a crotch of the main stem of the tree, so situated that it was quite exposed to view, there being no foliage for many feet above. In the gloom of the willow swamp, however, the nest was scarcely distinguishable to an observer on the ground. It appeared that the nest was rather accidental in location, for generally this warbler seemed to prefer the tufts on horizontal branches of the firs and pines.

The nest shown in Plate XIII., is two and one-fourth inches in height, and three inches in diameter. The cavity averages one and seven-eighths inches in diameter, and is one and threefourths inches deep. The structure is strongly made of dried weed stems, vegetable fibres, and soft grasses, with feathere 
and horsehair worked into the inner portion of the wall for lining. The eggs are grayish white, with specks and blotches of blackish brown principally at the larger end.

As stated in a preceding paragraph, an extended search of the locality between the mouth of Swan River and the site of the nest, a region about a half mile in length, failed to reveal a second nest of this warbler. It seemed to the collector that every tree in the willow tract was closely scanned, but without results; hence the reason for the statement that this nesting seemed to be accidental or unusual. On July 2 a nest of Audubon's warbler was found along the lake, upon a rocky ridge which precipitously faced the water. It was in a medium-sized fir tree near the shore, and was about twenty feet from the ground, the site being five feet from the trunk, near the end of a branch. Both parent birds were industriously feeding the young birds in the nest.

\section{YHLLOW WARBLER, Dendroica aestiva (Gmel.)}

The yellow warbler is a common summer resident in the Flathead region, though outnumbered by the American redstart in the willow swamps and by Audubon's warbler in the upland localities. The wide distribution of this warbler, and its preference for younger vegetation in selecting sites for its nest, give it more extended acquaintance than can be claimed for most of the other warblers. The predominance of the clear yellow in its attire makes this beautiful "yellow-bird" an attractive mark for the eye of the observer, and its vibrant chant causes the groves to ring with melody in the mating and nesting season; thus striking color, noticeable sing, and neighborly manners add to the popularity of the so-called "wild canary", and serve to make it the best known representative of its family.

The accompanying illustration, Plate XV., is of a nest of the yellow warbler taken on June 18. It was made in an upright crotch ten feet from the ground in a clump of syringa which grew on the margin of Swan River near the end of the bridge. As can be seen in the figure, the nest materials are woven around the oblique twigs forming the site. It is a thickly felted structure, measuring two and three-fourths inches in height and in diameter, the cavity being one and seven-eighths inches in diameter and one and one-half inches deep.

The nest is made principally of fine grasses, with which are 
woven grayish downy materials, fibres of weed bark, and bits of gossamer, with a lining of horsehair. This nest is almost gray on its exterior surface from the amount of gossamer and bleached vegetable fibers. It contained five fresh eggs. They have a grayish white ground, variously flecked with pale brown. Generally the dots are gathered into an imperfect wreath around the larger end of the egg.

One of the handsomest nests of this warbler ever examined by the writer was noted in a haw tree near the point of land at the mouth of Swan River on the western side. This nest was lined throughout with white down of vegetable growth, giving the inner wall of the structure the appearance of the material in a lady's white slipper. As the nest contained young birds at the time it was found, it was left for further use of the owner; but when the place was re-visited about a month later, to secure the nest, it could not be found, having been destroyed while laborers were grubbing in that locality.

In this connection it will not be amiss to mention two nests of this warbler found late in the fall in another region. Both had evidently served their purpose as homes for families of young warblers; but under the soft texture of the base each of the nests had two eggs of the cowbird inugly covered. It was apparent that when the nests were finished, the cowbird had appropriated the snug cots before the owners had taken permanent possession, and had left their eggs for the care of the warblers. The warblers, however, being apparently unwilling to take upon themselves the care of the cowbird offspring, had immediately placed additional material upon the eggs of the parasite, thus defeating the aim of the cowbird, and relieving themselves of unwelcome inmates in their home. Such action of the yellow warbler, to avoid the care of the young cowbirds, is by no means uncommon.

Following the preceding paragraph, it will be in place to state that in no instance was evidence of the cowbird found in the Flathead region as one of the breeding residents. Nests of vireos, sparrows, warblers, and other species were examined, whose homes are generally imposed upon by the parasite, but no nest was found containing an egg of the cowbird. It seems unusual that such should be the case; it would be far stranger that the cowbird should be uncommon in this region in the nesting season. 


\section{WARBLING VIREO, Vireo gilvus (Vieill.)}

The warbling vireo appeared to be one of the most abundant species in the vicinity of the Biological Station. Every locality described was enlivened by the presence and notes of this charming greenlet. On the day of our arrival at the Station, June 14, a nest of the warbling vireo was taken in the lot across the road from the laboratory grounds. This nest was eight feet from the ground, suspended in a small fork near the extremity of an oblique stem, and contained four eggs quite advanced in incubation. The female occupied the nest when it was discovered, and the male was singing in an evergreen tree above the clump containing the nest. While the nest was being disturbed, the female remained in the immediate neighborhood, uttering ditties similar to those of the male.

On the following day, June 15 , a nest of this species was noted in a swampy woods at the right of Swan River. It was nine feet from the ground, situated as usual in a dependent fork, and contained three fresh eggs. As in the preceding instance, the female was attending to her home duties, while the male was singing near the nest. Indeed, the song of this vireo is generally a sure index of a nest in the immediate vicinity, during the nesting season.

East of the Swan River bridge and to the left of the road leading thence southward, there is an extensive area of low, damp woodland, which forms a very desirable home for the vireos, the olive-backed thrush, and other species. A nest of the warbling vireo was examined in these woods on June 18. It was six feet from the ground, pendent in a fork near the end of a low sprout. Four fresh eggs formed the complement, upon which one of the parent birds was sitting when disturbed by the collector.

Flanking the road and adjacent woods, a rocky ridge stripped of tall timber by fires and overgrown with maple clumps and small evergreens, invites the attention of the collector. On June 20, a nest of the warbling vireo was found there, situated nine feet from the ground in a maple clump. It contained four eggs advanced in incubation.

The woods around Estey's Pond form coverts for numbers of warbling vireos. While exploring the margins of this pond on June 22, we took a nest of the warbling vireo from a fork in bushes five and one-half feet from the ground. The branch sustaining the nest overhung a trail along the pond, so that anyone passing would likely brush against the nest

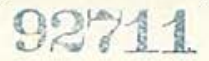


with his head. This nest contained four eggs advanced in incubation.

The eastern or left bank of Swan River, from the bridge to its mouth, has a well-worn trail made by fishermen. A nest of the warbling vireo was noted on June 23 beside this path. It was six feet from the ground, in a clump of syringa, and contained three well-fledged young. This instance and the preceding one illustrate a common tendency of several familiar species to establish their homes along paths and trails in general use, a trait mentioned in our notes concerning the nidification of the olive-backed thrush.

The woods across the road from the laboratory grounds furnished us another note for June 26. A nest of the warbling vireo was found suspended as usual in a fork in a small clump of maple, eight feet from the ground. This nest contained four eggs, in which incubation had begun.

From the date last given until the end of our observations on July 5, nests of this vireo were examined each day, but at this period of the nesting season no more nests were found containing eggs. The foregoing notes will suffice to show the general location of the nest-site and the usual nest complement.

Plate XII. shows an illustration of a typical nest of this species.

The nest figured in the illustration is an unusually handsome structure, having its exterior covered loosely with fragments of gossamer and bits of soft birch bark, besides showing the shreds of wasp paper woven into the outer wall. The walls are made of fine grass fibers resembling delicate pine shavings. An examination of the illustration will show the manner in which the nest is suspended by its brim. The cavity is two and onefourth inches and two inches major and minor axes of the brim, the walls curving outward below the rim to give the cavity a sub-spherical form.

The form of this species found in the Flathead region is described under the subspecific name of Vireo gilvus swainsonii.

\section{RED-EYED VIREO, Vireo olivaceus (Linn.)}

This persistent songster is fully as abundant in the Flathead region as I have found it anywhere in its Mississippi Valley range. Everywhere throughout the wooded localities, either in the low willow areas or in the heavily timbered uplands, 
the song of this tireless musician can be heard in the nesting season. Frequenting the treetops with other avian neighbors, it frequently falls a victim when the collector is hoping to obtain a more valuable specimen. In general, it haunts a somewhat higher level of the woods than does the warbling vireo, as its nesting sites average farther from the ground; and it does not manifest the same degree of confidence in human associations as is noticeable in the manners of its congener last described. On the day of our arrival at the Station, the red-eyed vireo was one of the commonest and noisiest (noticeable in song) birds of the woods, heard everywhere at all times during the day. Owing to the fact that this vireo generally chooses a higher site for its nest than the warbling vireo, not so many notes were made regarding its nidification.

On June 16, an apparently abandoned nest of the red-eyed vireo was found in the swampy woods at the right of the mouth of Swan River. It was pendent in a fork of an oblique willow stem, twelve feet from the ground, and contained four fresh eggs, one of which was partially destroyed, as it had a large hole pecked or gnawed in its side. The damage may have been done by a squirrel or chipmunk, the latter being a very active agent in the destruction of eggs of native birds.

On the afternoon of the same day, June 16, a nest of the redeyed vireo was taken in the low thicket immediately west of the laboratory. This nest was nine feet from the ground, in a drooping fork of a haw tree. The complement was five fresh eggs. Like the structure of the warbling vireo described in the preceding notes, this product of the red-eyed vireo is finished exteriorly with bits of gossamer, birch bark, and flakes of wasp paper. It is attached less securely to the fork, and the walls are somewhat thinner. The materials are much the same, though those used by the red-eyed vireo are darker and less attractive. In interior measurements the nests are about the same size. The eggs of these vireos are quite similar, having a clear white ground, with snecks of blackish brown irregularly and sparsely scattered over the surface, frequently more numerous at the larger end. The eggs of the red-eyed vireo average slightly larger than those of the warbling vireo.

In Plate XI. a nest with a full complement of eggs is shown. Compare with Plate XII. 


\section{CEDAR WAXWING, Ampelis cedrorum (Vieill.)}

The cedar waxwing is probably abundant everywhere throughout Montana. In the Flathead region it was found commonly in all localities mentioned in these notes. In the vicinity of the Station it finds adequate supplies of food in the haws and elder berries in season. As a flycatcher, the cedar waxwing is as expert as the kingbird and pewees, for from a station in the top of some denuded tree, it will sally forth for long distances, take its prey with expert skill, turn in air, and return to its post in true flycatcher-like manner. Except in the nesting season, the cedar waxwing manifests its social disposition by flocking with others of its kind, resembling the crossbill in its restless movements from one treetop to another.

My first nest of the cedar waxwing was found on a trip to the Cedar Islands, at the head of McGovern's Bay, which forms the upper end of Flathead Lake. The nest was in a cedar tree, near the extremity of a horizontal branch at the top of the tree. The site was eighteen feet from the ground, but about nine feet above a rocky ledge under the tree. The structure was made entirely of the long dark green lichen or moss which droops so plentifully from tamaracks and other evergreen trees. The mossy material was pinned together with needles from the pine tree. This nest contained five eggs, in which incubation had begun, June 24.

On July 1 a nest of this species was found in the lot across the road from the laboratory. It was made in the top of a low fir tree, the situation being similar to that usually selected by the olive-backed thrush. The nest was nine feet from the ground, made among twigs against the main stem of the fir. Itfurther resembled the work of the thrush in being placed upon a foundation of coarse dried grasses and weed stems. The nest proper, however, was constructed of lichen pinned together with needles, as described in the note upon the foregoing nest. The nest cavity was two and one-half by three inches, major and minor axes, and two inches deep. The complement was five eggs, somewhat advanced in incubation. The eggs are ashy gray, marked irregularly with spots of blackish brown.

\section{TREE SWALLOW Tachycineta bicolor (Vieill.)}

This beautiful swallow was found nesting abundantly in all suitable regions. Estey's Pond, whose margin was fringed with 
dead trees containing cavities made by woodpeckers in preceding seasons, was a favorite resort for this species. East of the ridge mentioned as flanking the Helena Club grounds and the road leading southward, was a depression which contained many tall boles with holes inhabited by the tree swallow. The islands at the head of McGovern's Bay formed attractive resorts for the tree swallow, and there we found the only nest examined containing eggs. The site of the nest was a cavity in a large cedar tree, about twenty feet from the ground, but not more than half that distance from the top of a rocky ledge beside the tree. The cavity was a natural crack in the decayed trunk, about a foot deep, in which a nest of soft chicken feathers had been made. On the day of observation, June 24, there was but one egg in the nest. The egg of this swallow is pure white, closely resembling that of the downy woodpecker, or the chimney swift.

\section{LOUISIANA TANAGER, Piranga ludoviciana (Wils.)}

The Iouisiana tanager is one of the bird beauties of the Northwest. The male, with his clear lemon-yellow attire, varied with crimson-hued head, is a striking feature of the evergreen woods. The female is not so attractively dressed, having a robe of olive instead of brighter colors. In voice, also, this species is worthy of unusual consideration. The male has a warble quite like that of the robin, though careful discrimination may note that it is uttered more hurriedly and sharply. Its usual call consists of two syllables, which may be represented by the word "truckee", accented on the last syllable.

It was my fortune to find one nest of this tanager, and that one contained young birds about three days old, on June 21. I had been in the vicinity of the nest repeatedly on previous days, but not until this occasion was my attention directed to it. The fact of having young at this time led the parent birds to disclose their secret by their anxiety, which had not been so great when I had been near the place while the nest contained eggs. The actions of other nesting birds in that particular clump of woods, however, had aided to cause me to overlook this tanager home on former occasions, for the bushes had claimed my attention to the neglect of the trees overhead.

The nest of the Louisiana tanager was in the woods across the road from the Station grounds. It was in a fir tree, twelve 
feet from the ground, placed near the extremity of a drooping horizontal branch. The style of architecture was similar to that of the grosbeak, rootlets being the principal material, which were woven into a loose basket; the surrounding material, however, afforded additional service in the nature of nest walls.

\section{LAZULI BUNTING, Passerina amoena (Say)}

The beautiful lazuli bunting is a bird of the bushes, clearings or burnt areas overgrown with shrubbery being its favorite resorts. In song and habits it is the counterpart of its eastern congener, the indigo bunting, Passerina cyanea (Linn.) Mounted in the top of a tall tree, it will chant at frequent intervals its monotonous song, seemingly in happy enjoyment of the sunshine.

Though the lazuli bunting is very common in the region under consideration, but one nest was found; however, no particular effort was made to find this one or another, chance leading the collector upon it while diligently searching for the nest of a less common species. It was in a growth of young tamaracks on a ridge along Swan River. The ridge had been fire-swept in a preceding season, and over the fallen trunks had grown the tamaracks and bushes. The nest was two and onefourth feet from the ground, slightly suspended among upright stems of sprouts growing among the tamaracks. The female was flushed from the nest, and while her home was being despoiled she manifested considerable anxiety, flitting here and there with her mate and chirping apprehensively.

The nest is figured in the accompanying illustration, Plate X. It is a rounded basket-like cup made of long dried grasses and weed fibers. The lining is made of fine grasses and scanty horsehair. The cavity averages two and one-fourth inches in diameter, and is two inches deep. The complement consisted of three fresh eggs, which are pale greenish-blue in color, almost white, unspotted.

BLACK-HEADED GROSBEAK, Habia melanocephala (Swains)

This beautiful western congener of the rose-breasted grosbeak, Habia ludoviciana (Linn.), is a common summer resident of the Flathead region. Its charming song is so nearly like that of 
the rose-breasted grosbeak that the listener who is acquainted with the latter might imagine that the eastern species had wandered beyond its elm and maple groves of eastern localities, and had taken up its residence in our western evergreen woods. The lower trees and thickets are more congenial to the black-headed grosbeak, haw trees being usually selected for nesting sites. Like its eastern relative, it is a tireless songster in the nesting season, everywhere proclaiming its presence by its rich, mellow expressions of content.

On our first exploring trip, in the afternoon of June 14, I found a nest of the black-headed grosbeak beside the road leading up Swan River on the eastern side. The nest was in a clump of saplings, built in a crotch twelve feet from the ground, among upright stems so small that a bundle of them had to be strapped together to support the weight of the collector. When the nest was discovered, the male was attending to family duty, a trait of the grosbeaks notable with the rose-breasted species. The nest is made loosely of weedstems and rootlets, with a lining of fine grass stems, all having a brownish color. The cavity is three inches in diameter, and one and one-fourth inches deep. The nest contained four eggs far advanced in incubation. They are light olive green, marked irregularly with specks and blotches of pale brown, usually more numerous on the larger end. One egg of this set was destroyed by a gust of wind, which carried the egg off a table and landed it upon a rock in the foundation of the laboratory. The nest with the three remaining eggs is shown in the accompanying illustration, Plate VI.

On June 19, a second nest was found in the woods at the right of the mouth of Swan River. As in the preceding instance, the nest was beside a road leading out upon the point at the river's mouth, though not generally used. The site was an upright crotch thirteen feet from the ground in a haw, near the extremity of an oblique branch. In this case the male was likewise sitting upon the eggs. The nest was made like the former, of brownish stems and rootlets, lined with fine grass stems. There were four eggs, which were advanced in incubation. This nest is also figured in an accompanying illustration, Plate IX. 
WESTERN CHIPPING SPARROW, Spizella socialis arizonae Coues.

This familiar species was everywhere abundant, and its wellknown familiarity and very general distribution caused it to receive little attention beyond the note regarding its presence in the various localities visited. Whether climbing rocky crests in search of juncos or threading the bushes in quest of other species, we were certain to find the omnipresent chipping sparrow, generally with an insect morsel in its mouth to hand over to its hungry younglings crouching in the bush.

Only one nest of the western chipping sparrow was taken, the record being for June 15. It was found in a bush near the edge of the woods at the right of the mouth of Swan River. The site was three feet from the ground, near the top of the bush. There were four eggs, in which incubation was well advanced. The nest is made altogether of very fine blackish rootlets, with a substantial lining of horsehair. The cavity is an inch and three-fourths in diameter, and one and one-half inches deep. These eggs are dingy pale green, marked principally with pale rusty brown in blotches of varying size. Besides these, there are blotches of black color irregularly found as markings.

\section{WRIGHT'S FLYCATCHER, Empidonax wrightii Baird.}

Though common as one of the breeding birds of the Flathead region, Wright's flycatcher seems to limit its residence during the summer to a very short season, only sufficient to rear its brood. Four nests of this flycatcher were taken during the period under consideration in these notes, and in each instance the female was taken to secure perfect identification; upon our return to the Station in the first week of August and during the month following, we were unable to secure a specimen of Wright's flycatcher in any of the localities where they had been observed earlier in the season. However, this flycatcher is unusually shy under observation, generally managing to place itself behind friendly foliage, hence its presence could be easily overlooked. It is more than probable, however, that like Traill's flycatcher, common in the same localities, it takes its departure for southern climes toward the end of July, or rather disappears from its accustomed haunts about that time. 
A nest of Wright's flycatcher was found on June 15 in the edge of the woods at the right of the mouth of Swan River. It was in an upright fork five feet from the ground, in a clump of maple sprouts. It contained four fresh eggs. The nest stands three inches in height and three inches in diameter. The cavity is one and seven-eighths inches in diameter, and one and one-half inches deep. The nest is constructed of grayish vegetable fibers and shreds of birch bark, with minute downy feathers woven into the inner wall for lining, together with fine grasses used sparingly. The eggs are pale creamy white.

The second nest was taken on June 18, on the ridge east of the bridge. It was ten feet from the ground, in a crotch near the top of a maple clump, and contained five eggs advanced in incubation. This nest was also made of long grayish vegetable fibers, the coarser ones being used externally. In the inner portion of the wall were woven small downy feathers, one noticeably yellow, besides cottony material which gave the lining a felted appearance similar to some nests of the yellow warbler, Dendroica aestiva. This nest is one and three-fourths inches average diameter and one and three-fourths inches deep, internal measurements. In outward dimensions it is the same as in the preceding instance.

The third nest was found on the eastern side of the ridge which lies east of the Swan River bridge. It was situated in a crotch four feet from the ground in a clump of maple sprouts. In construction and appearance it is similar to the two nests described. It contained three eggs, the set being evidently incomplete, as the eggs were quite fresh, though the female was sitting when the nest was discovered. The record is for June 20.

The fourth nest of this flycatcher was taken on June 25, having been found some days before but left for further examination. It was in the edge of the swampy woods at the right of Swan River, eight feet from the ground in a crotch against an oblique stem in the periphery of a clump of maple sprouts. This nest contained four eggs, in which incubation had well begun.

Thus our notes show that the average distance of these nests from the ground was somewhat less than seven feet; all were placed in uright forks or crotches in clumps of maple, generally in the periphery of the clump; all were made of grayish vegetable fibers, having downy feathers woven into the inner surface of the walls; and the complement generally consists of four or five eggs. 


\section{KINGBIRD, T'yrannus tyrannus (Linn.)}

The kingbird is common as a summer resident in the localities mentioned in these notes. It is seen most numerously along the margins of the lake, in the willows whose bases are submerged by the back water; there it is noisy and ubiquitous, exercising its sway over its claimed domains with its usual pugnacious disposition, and rearing its broods in the low trees of the lakeshore. Several families were noted along the margin of Daphnia Pond; and because of an unusual nesting site selected by a pair of kingbirds along the shore of this pond, this note is made. The nest was made in a cavity in a dead, denuded tree, the cavity being broken open so that the nest was exposed to view on one side, and the sitting bird easily seen as she faced the entrance or front of the cavity. As she sat thus with observant eyes for passing events, the male frequently visited her with some dainty morsel for her refreshment. The cavity was about eighteen feet from the ground. The bare stem, from which the branches had been swept by fire, resembled a pole in appearance.

The kingbird in this region chooses sites much nearer the ground and more exposed in situation than it does in more eastern localities. On July 6, as we landed from the launch that had carried us to the foot of Flathead Lake, it happened that a nest of the kingbird containing young birds was in a dwarf tree near our landing-place. A crowd of Indian lads assembled to witness our landing, and some of them espied the nest with its noisy young. It is needless to state that in a few minutes the younglings had fallen victims to the heartlessness of the crowd, being pitched out upon the water and then pelted with stones as they fluttered helplessly upon the ripples.

The dwarf trees and bushes found generally along the streams of the Flathead Reservation are commonly populated by the kingbird, and most of the nests are so low that they can be examined without climbing or reaching. In notes made later in the Reservation we find a nest in a corner of a rail fence, at a point about half the height of the fence; another in a bush by a streamside not three feet from the ground; such instances are the rule and not the exception.

WESTERN NIGHTHAWK, Chordeiles virginianus henryi (Cass.)

The western nighthawk is very common in the Flathead 
region. Its wonderful aerial evolutions at dusk, and in the afternoon of cloudy days, have given it extended acquaintance, hence it is more generally known than many of our avian neighbors. Not all persons, however, who have witnessed its volatorial powers, have heard the strange sound, resembling a steamer or gong whistle, which it utters sometimes as it plunges downward in its flight. The rocky ledges near the Station afford the nighthawk suitable nesting sites, and during the day we frequently startled the drowsy birds as they sought retirement after a period of activity at dusk and in the early morning.

One nest of the western nighthawk, or rather one set of eggs, was found, and that was taken on the last day of our collecting trip at the Station, July 5. The two eggs were on a bare rock back of the store at Holt. No nest was made for them. They were quite advanced in incubation. In color they were stone gray, with spots of blackish brown.

\section{RED-NAPED SAPSUCKER, Sphyrapicus varius nuchalis Baird.}

Most of the woodpeckers nest early, hence little attention was given to their nesting habits; moreover, most of them nest in sites which require strenuous climbing to reach, and as this was not our purpose while making these notes, the woodpeckers were generally passed with little notice. A family of red-naped sapsuckers, however, had selected a site so obvious that this note is given to them. It was in a dead aspen in the margin of the grassy slough in the woods at the right of Swan River, mentioned in an introductory paragraph. When the birds were observed, they were feeding their young in the cavity, the entrance being a small sub-circular hole about eight feet from the level of the water, which had surrounded the foot of the tree. On June 26, when the note was made, the young appeared to be quite well-grown, judging by the buzzing clamor they raised when the parent bird stood at the entrance with food.

\section{BLACK-BILLED CUCK00, Coccyzus erythrophthalmus (Wils.)}

While I am aware that the identification is questionable, I submit the following note for what it is worth. No specimens 
of the black-billed cuckoo were taken or seen in the region around Flathead, a fact which makes the note of even less value; however, subsequent observation may give additional light upon the question here raised regarding this species as a summer resident of the Flathead region.

On July 3 the writer picked up an egg in a path through the swamp-woods at the right of Swan River. In size and appearance, the specimen closely corresponds to the egg of the black-billed cuckoo, or the western representative of the yellowbilled cuckoo. It had evidently been dropped in the path, and was fractured somewhat on the side on which it rested, but it made a fair specimen awaiting identification.

\section{AMERICAN OSPREY,Pandion haliaetus carolinensis (Gmel.)}

The American osprey is the most noticeable bird of prey in the vicinity of the Station. One of the regular noises of the day was the peculiar whistle of the osprey, which has somewhat of a ventriloquial effect, as it seems to issue from a point nearby when the author is much farther from the hearer. The cry is uttered most frequently when the birds are approaching or leaving the nest, or wheeling in the neighborhood of their home.

On the bank of the river opposite to the Station, in the Helena Club grounds, a pair of ospreys had established a home at the top of a lofty pine stub. The site had been used by ospreys in previous seasons, and was evidently a regular tenement. At our advent to the neighborhood, on June 14, the nest contained well-fledged young, which kept the elders industriously engaged in supplying the demand for fresh meat in the form of fish. We left the place on July 6 , but upon our return on August 6, the nest was still nsed as a place of resort and as head-quarters for the parent birds in providing for the wants of the dependent youngsters. The nest is shown in Plate VIII.

\section{SHARP-SHINNED HAWK, Accipiter velox (Wils.)}

Owing to the retiring habits of this little Accipiter in the breeding season, few notes were made upon its occurrence near the Station. The thickets of the low swamp at the right of Swan River doubtless formed congenial resorts for this hawk, 
and as the same localities were abundantly populated by small birds which the sharp-shinned hawk is known to prey upon, there was little occasion for it to stir far abroad. Indeed, it is unusual for this hawk to be found far from its nesting site; if either of a pair is observed foraging regularly in a thicket in the early breeding season, a nest is likely to be found in the vicinity at the appropriate time.

A nest of the sharp-shimmed hawk was taken on July 3, in the swamp woods at the right of Swan River. A most admirable site had been selected. Two large birches grew in a clump of fir trees, so that the stems of the birches and a fir formed a triangle measuring about two feet on each side. The nest was made on fir branches between the two birches, eight feet from the ground, being thus exposed to view only upon one side. It was a mass of small twigs fifteen inches in diameter, the cavity being six inches across and one and one-half inches deep. As is usually the case in the architecture of this hawk, there was nothing whatever to serve as lining. The complement was four handsomely marked eggs, well advanced in incubation.

The eggs of this set are quite variable in marking, following the rule with eggs of the sharp-shinned hawk. The generai ground color is pale bluish-white. Upon this two of the eggs have their larger ends entirely covered with blotches of bright umber, the thickness of the markings giving the appearance of one large blotch. Over the remainder of their surfaces there are scattering marks of the same color. The third egg has the blotches arranged in a wreath around the smaller end, forming a likeness to a band of pale umber, with scattering marks upon the remainder of the surface. The fourth egg has the markings chiefly upon the larger end, but not so solidly as in the case of the two first described; in addition, the fourth egg has several prominent blotches of blackish brown, seemingly upon the umber markings. Of the eggs of this species, Oliver Davie says: "The eggs of the sharp-shinned hawk, Mr. Norris states, are subject to great variation in markings, and yet, as a rule, they can be identified at a glance. With the exception of the sparrow hawk, they are the smallest laid by any of the hawks found in North America, and among the most beautiful eggs of any of the Raptores. Their ground color varies from bluish-white to grayish-white, spotted, blotched, speckled, streaked and clouded with light fawn color, 
burnt umber, chestnut, lavendar-gray, chocolate, russet-brown and cinnamon, exhibiting an endless variety of bold and indistinct patterns of coloration and design."

\section{SPOTTED SANDPIPER, Actitis macularia (Linn.)}

The spotted sandpiper was found breeding in abundance along the lakeshore. Wherever there was sandy beach or gravelly shore to any extent, there the spotted sandpiper could be heard uttering its "peet weet", and could be seen "teetering" in its characteristic manner as it gleaned along the margin of the water. The long sandy stretches between the mouth of Swan River and of Flathead River were favorite resorts of the sandpipers, and there they could be heard calling at all hours of the day, and late into the evening. This shore was being gradually exposed by the falling water of the lake, and the great sandy flats were exactly suited to the tastes of the little "teeter-up".

The first nest of the spotted sandpiper was found on June 18 , on the sandy point at the right of the mouth of Swan River. The female was flushed from the nest about dusk. The site was under a bare drift log, and was made in a depression three inches in diameter and one inch deep. It was made of coarse weed-stems, bits of bark and rubbish. The complement. was three eggs, two placed small ends together, the third placed along the small ends of the other two. Incubation was quite advanced in these eggs. Their ground color is a polished clay, upon which are spots and blotches of dark reddish brown and blackish-brown.

My notes for June 20 record a nest of this species found on the wooded island below the Station, in Swan River, the island afterward becoming part of the mainland as the water of the river receded into its narrow channel. The nest was made in the open sand, though under trees, about ten feet from the water. It was three inches in diameter, and one and onehalf inches deep, made of refuse rubbish banked around the depression in the sand. There were four fresh eggs placed small ends together and downwards, almost half buried in the loose materials of the structure.

A third set of eggs of the spotted sandpiper was taken on June 25, on the same sandy point mentioned in the former instance. The nest was in a little clump of sprouts, about twenty feet from the water, and well concealed on all sides. 
It was three inches across, one and one-fourth inches deep, and was made of pieces of dried weed-stems and rubbish. There were three eggs, in which incubation had begun.

On June $2 \%$, a nest of the spotted sandpiper was found on the sandy beach at a point near the mouth of Flathead River. It was in a willow bush about twenty feet from the water, made of drift rubbish, measurements as in the preceding instance. This nest contained four fresh eggs.

A set of eggs is shown in Plate XIV.

\section{Supplementary 仿otes, 1901}

Fourteen nests of olive-backed thrush, Turdus ustulatus swainsonii, were examined in the region under consideration, in 1901. Of these, the highest site was eight feet, the lowest three and one-half feet, the average being six and one-half feet from the ground. Ten of these nests contained four eggs or young as the complement, and of the remainder, two held three fresh eggs, which might constitute incomplete sets. Nine of these nests were in upright crotches, of which eight were in maple saplings and one in a birch; the other nests were in firs, on horizontal branches beside the main stem. The first was found June 18, with fresh eggs; the last one contained eggs quite advanced in incubation, July 5.

A nest of the willow thrush, Turdus fuscescens salicicola, was found in the swamp-woods bordering the Jocko River at Selish, on June 16. It was made on a heap of dried and decayed leaves on fallen branches, one foot from the ground. The nest was similar in construction to that described on page 12 . It contained four eggs, incubation well advanced. From the frequent notes heard, it seems that this species is more common than we supposed from our observations in the preceding season.

A nest of the American dipper, Cinclus mexicanus, was taken at Lake McDonald, from a shelf of rock about four feet above the water of the lake shore. It was constructed entirely of green moss, and was situated in an angle of the rock, the site giving it an ellipsoidal form. It was nine and one-half inches long, and seven and one-half inches high, with a width of seven inches from front to back. The entrance was a sub-circular hole three inches in diameter, near the middle of the 
front side immediately above the floor. The walls varied from one to two inches in thickness, forming a neat spherical cavity as yet unoccupied, June 24.

A nest of Wilson's warbler, Sylvania pusilla (Wils.), was taken on June 24, in the vicinity of MeDonald Lake. It was found under the projecting shelter of a moss-covered, decayed prostrate $\log$ in a dense arbor-vitae swamp-woods. The brim was flush with the surroundings in decayed leaves, moss, and punk. The walls were ruade of coarse weed fibers, and the lining was a scanty layer of reddish-brown fibers and horsehair. The cavity measured two inches in diameter, and one and one-fourth inches in depth. There were four eggs, incubation quite advanced, and one egg was broken in blowing. The female was startled from her cozy home as I stepped over the $\log$ almost over the nest. In size and appearance, the eggs closely resemble those of the chickadee, having a whitish ground irregularly marked with fine specks of thin reddish-brown, the markings being thickest at the larger end.

On June 29, a nest of western yellowthroat, Geothlypis trichas occidentallis Brewst., was taken on a mountain-side near Flathead Lake, at an elevation of 5,000 feet. It was in the base of a low bush, eight inches from the ground. It was made entirely of coarse weed-stems, with a lining of horsehair. The cavity was one and five-eighths inches across, and one and three-eighths inches deep. There were four fresh eggs, which had a pinkish white ground, with irregular dots and blotches of thin reddish-brown. Besides this nest, several others of the year were found, one in Daphnia Pond in a tuft of rushes being made of coarse rush blades, with a scanty layer of fine stems for lining.

Macgillivray's warbler was noted more frequently than in 1900, though no nests with eggs were taken. On June 30, a nest of this warbler was found in the base of a low bush in the woods near Flathead Lake. It was eight inches from the ground, made of coarse dried grasses and lined with horsehair. The cavity was two and one-fourth inches in diameter, and one and three-fourths inches in depth. I accidentally brushed against the nest, which was filled with fledglings about ready to fly, and they fluttered out quickly into the adjacent bushes, entailing a great degree of chirping by the parents to collect the scattered younglings.

This year we were more fortunate in our search for the home 
of the junco. A nest of Shufeldt's junco was found on July 9 , in the woods near the base of MacDougal Peak. It was on the side of a small moss-covered mound, which had been formed by the uprooting of a tree in other years. The nest was in a recess, and was made of coarse weed-stems and lined with fine light grasses. It was four inches across and two inches high after removal from the site. The cavity measured two and one-half inches in diameter, and one and onefourth inches in depth. Its complement was four fresh eggs, which were greenish-white, marked with reddish-brown, the larger end as usual having the greater amount of markings.

While at Sin-yale-a-min Lake, a number of used nests were examined, the work of the black-headed jay, cyanocitta stelleri annectens (Baird). They were found in small firs, invariably along the streams, and generally about twelve feet from the ground, on horizontal branches beside the main stem. The chosen site was usually about three-fourths the height of the tree. They were made of an outer framework of coarse twigs, and were about eight inches across in exterior measurement, and five inches high. The outer wall was made of muddy moss and coarse stems, the lining being of coarse brown rootlets. The cavity averaged four and three-fourths inches in diameter, and three inches deep.

On June 28, I found a nest of the black-headed jay near a bridge over a small stream where we stopped for lunch. The nest was eighteen feet from the ground, in a stout upright fork of the main stem, which leaned over the water. It was made as described in the foregoing paragraph, having an outer framework of coarse twigs, walls of mud about a half-inch thick, an inner wall of coarse black rootlets, and a bedding of finer rootlets. There were four eggs, on which the female was sitting. She was secured for identification, and later, when the male came near, with a mouthful of grasshoppers, he was also taken. The eggs were quite advanced in incubation. They were light green in color, irregularly spotted with dark-brown. About twenty feet from the tree containing this nest was another with an old nest similar in construction, situated in a small fir as previously described. It is likely that the nest with eggs was a second nesting of this pair of jays; if such is the case, it will account for the late date of nidification, as the usual season of this jay had apparently closed in the neighborhood. 
While passing through St. Ignatius, on the Reservation, our attention was attracted by the Arkansas kingbird, Tyrannus verticallis Say, and a nest was found in a corral, on the groove of a windlass, beside one of the uprights. It was about twelve feet from the ground, and was made of soft fibers, stems, and cordage. It contained three eggs, in which incubation had begun. The eggs of the Arkansas kingbird closely resemble those of the kingbird, being cream-white with irregular spots of reddish-brown.

\section{Conclusion}

If the foregoing were intended to be a list of the breeding birds of the Flathead region, there are many notes which might be incorporated in this report. However, it is intended simply as a record of what was done in the period mentioned; hence every note stands for a nest or specimen actually seen. On June 18, a brood of young ducks was led to the water by the parents, American golden-eye, Glaucionetta clangula americana Bonap., from a hole in a cottonwood near the boat-house on the Helena Club grounds. The parent birds were observed visiting and leaving the hole by younger members of our party, and upon their reporting the matter to me, we went to the place, to find that the family had taken to the water and doubtless forever abandoned their woody cell. On another occasion, when a pleasure party was spending a day near the bridge, one of the boys discovered a nest of a hummingbird, doubtless the rufous hummingbird, Selasphorus rufus Gmel., as it was taken from bushes overhanging the bank of Swan River. Before it was brought to my notice, the two eggs were lost and the nest destroyed. These instances are mentioned to show that no attempt has been made to prolong this list beyond the actual observation of the collector, nor was it the intention to secure a lengthy list. As a record of private collecting, it is given here in the desire to contribute to a more general distribution of the natural history data of the state. 


\section{Tist of JBirds of the flathead Take Region}

List of birds, with notes on their habits and distribution, observed in the Mission Mountains, the Mission Valley, and at Flathead Lake. The list comprises the birds seen from June 5 to August 29, 1900. Skins of most of the species here mentioned are deposited in the museum of the University. The numbers correspond to the A. O. U. check list.

4. AMERICAN EARED GREBE, Colymbus nigricollis californicus (Heerm.)

On June 20, 1901, a brood of American eared grebe was seen on Sin-yale-a-min Lake. There were nine or ten specimens in the family, and three were taken. The brood had evidently been reared on the lake, as the youngsters were incapable of extended flight, though they were in full plumage. A specimen was taken later at Mud I.ake, near Flathead.

6. PIED-BILLED GREBE, Podilymbus podiceps (Linn.)

Not common at the northern end of Flathead Lake. One specimen noted on the eastern shore, below the mouth of Swan River.

\section{\%. LOON, Urinator imber (Gunn.)}

Common on Flathead Lake, singly and in pairs. Also common on Swan Lake, where its clear laughing calls resound far over the little valley enclosing the lake. Not noted at McDonald Lake.

It is not likely that the Loon is more than a summer visitant to Sin-yale-a-min Lake. This sheet of water is a desirable stopping place for passing birds at nightfall. A pair of loons spent one night at the lake during our visit, and an effort was made to secure a specimen the next morning, but without success. 


\section{RED-THROATED LOON, Urinator lumme (Gunn.)}

A female of this species was taken at Mud Lake, near Flathead, on July 15, 1901. It was alone, though several American mergansers were near it.

\section{WESTERN GULL, Larus occidentalis Aud.}

A common visitor at the northern end of Flathead Lake. A specimen was taken on Aug. 29, at the sand-bar near the mouth of Flathead River. associating with Larus delawarensis and Sterna forsteri.

\section{RING-BILLED GULL, Larus delawarensis Ord.}

A regular visitor to the upper end of Flathead Lake, appearing in pairs and flocks of eight to twenty, generally after boisterous days on the lake. It manifests unusual curiosity, as a boat or launch will attract it to hover about, often to its harr:. Specimens were frequently taken, Aug. 23, 24, and following dates.

\section{FORSTER'S 'TERN, Sterna forsteri Nutt.}

Irregular visitor to the northern end of Flathead Lake. On Aug. 23, a specimen was taken near the mouth of Swan River, from a small flock that flitted capriciously over the water.

129. AMERICAN MERGANSER, Merganser americanus (Cass.)

On Aug. 23, a flock of six or eight mergansers appeared in the bay immediately west of the station, near the boat landing. A specimen was taken from this flock on Aug. 24, and thereniter this fishing duck was regularly noted. When one of the flock sucreeded in capturing a fish, the others would pursue the successful fisher, and a playful scuffle for possession of the prey would ensue, in which the victim was generally dismembered by the harsh teeth cit the captors.

131. HOODED MERGANSER, Lophodytes cucullatus (Linn.)

On July 15, 1901, a female hooded merganser was taken 
at Mud Lake. This was the only specimen noted, though this merganser is common in this region as a regular resident.

\section{MALLARD, Anas boschas Linn.}

This fine duck is a common migrant at the upper end of Flathead Lake, appearing in flocks there as elsewhere. A specimen was taken on Aug. 24. Numbers were noted at the right of the mouth of Flathead River, where a small cove offered them convenient anchorage. It often breeds in the neighborhood.

\section{GREEN-WINGED TEAL, Anas carolinensis Gmel.}

A flock of green-winged teal appeared on Daphnia Pond about the middle of August, and a specimen was taken on August 17. Thereafter this teal was noted regularly on the pond, and in the mouth of Swan River.

\section{PINTAIL, Dafila acuta (Linn.)}

The pintail doubtless breeds at the north end of Flathead Lake, as specimens were regularly noted in the swampy area between Swan River and Flathead River, during our observations in June. Numbers were accumulating in the cove west of the mouth of Flathead River during the latter days of August, with the mallard, green-winged teal, American golden-eye, American merganser, and other species.

\section{WOOD DUCK, Aix sponsa (Linn.)}

A brood of young wood ducks appeared on the grassy slough in the swamp-woods between Swan River and Flathead River, and a young male was taken, July 31,1901 . Residents of the neighborhood report that the wood duck is disappearing, being seen much less frequently than it was several years ago.

\section{AMERICAN GOLDEN-EYE, Glaucionetta clangula amer- icana (Bonap.)}

A pair of American golden-eves were seen about Sin-yale-amin Lake at rarious times, and one specimen was taken. On the little pond in the ravine to the southwest, a family of 
American golden-eye was found, and several specimens of the young were taken with the parent birds. Every little sheet of water, along whose margin cavities can be found in convenient trunks, seems to have its family of American goldeneye. This species appeared to be by far the most abundant of the summer ducks in the Flathead region.

A common breeder at the north end of Flathead Lake, and on the adjacent ponds. Specimens were frequently taken, in June and in August. The numbers are increased by migrants toward the end of August.

\section{BUFFLE-HEAD, Charionetta albeola (Linn.)}

On July 30, 1901, a flock of young buffle-heads was noted at the head of Flathead Lake, and a specimen was taken for identification. It is likely that broods are commonly reared along the lakeshore, as several families are regularly observed to appear on the lake at the appropriate season.

\section{CANADA GOOSE, Branta canadensis (Linn.)}

Abundant during the migration early in August, appearing in flocks of ten to twenty on the sand-bars near the mouth of Flathead River. When approached by the observer, a flock will line up in single file along the shore before taking flight, and thus take wing while the observer is beyond shotgun range.

\section{AMERICAN BITTERN, Botaurus lentiginosus (Montag.)}

An American bittern was seen at nightfall on June 25, 1901, flying low over our camp at Post Creek. On July 16, 1901, a specimen of American bittern was taken in the reedy bog fringing Mud Lake.

\section{SORA, Porzana carolina (Linn.)}

The Sora occurs commonly on the reedy ponds and marshy areas of the lake shore. A pair inhabited a small weedy opening in the swampy woods between Swan River and Flathead River, and others were noted at Daphnia Pond. Specimens were taken at both places. 
223. NORTHERN PHALAROPE, Phalaropus lobatus (Linn.)

Occurs regularly on the migrations at the north end of Flathead Lake. A specimen was taken near the mouth of Swan River, August 2\%. It generally appears with the yellow-legs, swimming along the water's edge somewhat beyond the depth of its companion, and feeding near it.

\section{WILSON'S SNIPE, Gallinago delicata (Ord.)}

This "Jacksnipe" is noted commonly near Flathead Lake. A specimen was taken on August 18, on the shore at the right of the mouth of Swan River.

\section{BAIRD'S SANDPIPEH, Tringa bairdii (Coues)}

Appears regularly along the lake shore about the middle of August, in flocks of fifteen to twenty, feeding along the water's edgein restless, irregular movement, and taking flight simultaneously upon sufficient alarm. In air the flock retains a close formation, sweeping low above the water, and generally flying some distance before alighting, if previously alarmed.

\section{SANDERLING, Calidris arenaria (Linn.)}

Regular migrant at the north end of Flathead Lake. Specimens were taken near the mouth of Swan River, August 29. It frequents the reedy shores, in company with the spotted sandpiper, Baird's sandpiper, and other shore birds.

\section{¿54. GRFA'TER YELLOW-LEGS, Totanus melanoleucus} (Gmel.)

Noted commonly on the pools of the Reservation, and along the creeks. A pair were taken on one of the pools when we crossed from Lake McDonald to Post Creek. Specimens were noted at Crow Creek, and also at the foot of Flathead Lake. Common near the mouth of Swan River, on the sand-bars near the boat landing, and also on the sandy shores between Swan River and Flathead River.

255. YELLOW-LEGS, Totanus flavipes (Gmel.)

Usually seen in company with Totanus melanoleucus. Speci- 
mens were taken on the pools of the Reservation. Common at the foot of Flathead Lake. Also common near the mouth of Swan River.

256. SOLITARY SANDPIPER, Totanus solitarius (Wils.)

This sandpiper was common on the Reservation, generally along the creeks. Specimens were taken on Crow Creek. In its habits it closely resembles the spotted sandpiper, though its larger size aids in distinguishing it from the latter. Two specimens were taken near the mouth of Swan River, August 8, and it was regularly noted in our daily lists.

261. BARTRAMIAN SANDPIPER, Bartramia longicauda (Bechst.)

The Bartramian sandpiper was found locally distributed over the Reservation, meadows near ranch-houses being the favored haunts. A family or small colony inhabited a meadow on Mr. Felsman's ranch, near Sin-yale-a-min Lake, where a specimen was taken, June 21, 1901. On the same day a young Bartramian sandpiper, yet in downy plumage, was captured alive on the prairie between Post Creek and Mt. MacDonald. Another pair of these birds was found on a ranch near the foot of Flathead Lake, and several miles up the Lake a small colony or family was noted, June 26.

263. SPOTTED SANDPIPER, Actitis macularia (Linn.)

Noted everywhere in the localities visited. Abundant as a summer resident along the north end of Flathead Lake. Nests were frequently found in June on the sand-bars.

264. LONG-BILLED CURLEW, Numenius longirostris Wils.

Young birds of this species were running about over the prairie when we crossed from Lake McDonald to Flathead I ake. Several young of the year were taken. The curlew was common in the vicinity of Flathead Lake, near Polson, where flocks were forming on the prairies.

273. KILLDEER, Aegialitis vocifera (Linn.)

The killdeer was common throughout the Reservation. Spec- 
imens were noted on the pools, and along the streams, as well as at Flathead Lake.

Frequently observed near the boat landing, on the gravelly bars of Swan River. Specimens were taken on August 8, and regularly noted thereafter.

\section{BOB-WHITE, Colinus virginianus (Linn.)}

This fine game bird has been successfully introduced in the locality between Flathead Lake and Kalispell, where the variations of meadow, grainfield, and brushy ravine are particularly suitable to the needs of the bob-white. His mellow whistle is delightfully gratifying to the ears of those who knew him in his native habitat, and we may hope that he will take kindly to his trans-mountain conditions. Friends of this partridge should see that he is permitted to adjust himself fully to his new environments and to multiply in peace, before he falls a prey to the desire to kill. No true sportman will molest the bob-white whose rich piping greets his ears, nor will he raise his destructive gun when a startled bird may whir away from the covert at his feet, until the numbers are sufficiently great to warrant the taking of an occasional bird.

29\% b. RICHARDSON'S GROUSE, Dendragapus obscurus richardsonii (Dougl.)

This form of the sooty grouse was common in the vicinity of the Sin-yale-a-min Lake. Specimens were frequently taken. In a trip to the summit of Sin-yale-a-min Peak, on July 12, chicks about three days old were taken with the female, at an altitude of 7,000 feet. The chicks were easily caught with the hand. Several similar instances indicate that this grouse nests much later than is usually given in data regarding its nidification, or that it is generally unfortunate in the issue of its earlier attempts.

This grouse was common on the slopes leading up toward Mt. McDonald, and elsewhere on the bushy hillsides. Specimens were frequently taken.

On June 23, a fine male Richardson's grouse was taken on the eastern side of the ridge east of Daphnia Pond. He was feeding on the red berries growing in profusion on the hillside, having his crop full when taken. When disturbed, he strutted among the clumps of sprouts, spreading his large, 
fan-like black tail, and puffing out the naked air-sacs on the sides of his neck. He did not attempt to fly or to make any effort to escape.

On August 16, a female Richardson's grouse was taken on the same hillside.

\section{PRANKLIN'S GROUSE, Dendragapus franklinii} (Dougl.)

Franklin's grouse was common in the vicinity of Lake McDonald. A female with young about two weeks old was taken on Mt. McDonald at an altitude of 7,500 feet. . Other specimens were taken near the lake. This grouse is the "fool hen" of popular reputation, by which name it is very generally known in this region.

300 b. GRAY RUFFED GROESE, Bonasa umbellus umbelloides (Dougl.)

The gray ruffed grouse was found as a common resident of the thickets near the lakes. At the time of our first observations, females with young just beginning to fly were frequently flushed. When disturbed with her brood, the female sometimes utters a strange hissing noise, and running at her disturber with inflated air-sacs and outspread wings, she presents a very peculiar appearance. At such times, when she does not threaten the observer, she slinks among the bushes uttering a cat-like "meow", which is a close counterpart of the characteristic feline cry. Toward the close of the warm July afternoons, these birds were most likely to be found near the water's edge; at other hours of the day, they generally resorted to the clumps of small firs.

Abundant in the swampy area between Swan River and Flathead River, where several broods were noted in June; also on the ridges east of the lake, where several families were found. By the first of August, young birds were taking to the trees and higher bushes when disturbed.

\section{8 a. COLUMBIAN SHARP-TAILEN GROUSE, Pedio- caetes phasianellus columbianus (Ord.)}

This grouse was observed in the meadows near Crow Creek, where it appeared to be common as elsewhere in the cultivated 
bottoms of the state. Hillsides near water-courses, along which are hay meadows and grainfields, are the summer resorts of this fine gamebird of the Northwest.

Abundant on the prairie between Flathead Lake and Kalispell. On Aug. 30, a large flock was seen beside the road a short distance beyond Holt. The open districts north of the lake form the regular resorts of this common gamebird, and every ranch doubtless has its flock of "chickens".

\section{MOURNING DOVE, Zenaidura macroura (Linn.)}

The mourning dove is not uncommonly noted in the Reservation, being observed most generally near the water-courses. We listed several specimens at Crow Creek, though no others were seen until we reached the head of the lake, and there only sparingly. It is evidently nowhere abundant in this portion of its range. Specimens were regularly noted along the road from the Station to Holt, near the margin of the swampy region between Swan River and Flathead River.

\section{MARSH HAWK, Circus hudsonius (Linn.)}

The marsh hawk is common along the foot of Flathead Lake. We did not note it elsewhere in the Reservation, though it is undoubtedly found at suitable localities along the watercourses.

\section{SHARP-SHINNED HAWK, Accipiter velox (Wils.)}

This spirited little accipiter was found regularly near McDonald Lake. On one occasion a specimen darting around a clump of dwarf trees nearly flew into my arms; seeing me, he quickly darted upward and tried to escape, but a fortunate shot brought him to earth.

This hawk was found nesting in the swamp woods between Swan River and Flathead River, where a female was taken when flushed from her nest, in which were four eggs, July 3. On August 16, a male sharp-shinned hawk was taken on the bushy ridge east of the road leading to Daphnia Pond.

\section{COOPER'S HAWK, Accipiter cooperii (Bonap.)}

Cooper's hawk was common along the cliff east of McDonald Lake. We frequently observed them feeding young, or heard 
the cries of the young as the elders brought supplies to their rocky eyries. Once we climbed about half way up the cliff toward a nest of young birds whose cries attracted us; but as we neared the site the elders quitted the place and the young birds ceased their cries, thus defeating our object of finding the nest.

On August 14, a male Cooper's hawk was taken on the road leading from the bridge up Swan River. Specimens were taken successively on August 22 and 23, on the ranch at the right of the mouth of Swan River. This hawk was not noted during our observations in June.

\section{$33 \%$ b. WESTERN RED-TAIL, Buteo borealis calurus(Cass.)}

This fine large hawk was found breeding along the eastern shore of McDona!d Lake. One specimen was taken.

A mutilated specimen of the western red-tail was found in the road through the woods leading to the point at the mouth of Swan River, August 22. It had probably been shot by one of the parties staying at the Club houses, and had fallen or been dragged there by one of the dogs scouring the woods for game.

\section{$347^{7}$ a. AMERICAN ROUGH-LEGGED HAWK, Archibuten lagopus sancti-johannis (Gmel.)}

The American rough-legged hawk was commonly seen soaring overhead above the woods and hills east of the lower end of Flathead Lake. Several efforts were made to secure a specimen, even to scaling the cliff in hopes of getting a shot, but the game was always beyond reach.

\section{GOLDEN EAGLE, Aquila chrysaetos (Linn.)}

The Mission Mountains and adjacent regions offer congenial resorts for the golden eagle. Frequently it was observed soaring over the ranges, but no specimen was taken, though effort was frequently made to get within range of one. A fine specimen was observed feeding on a carcass and it allowed us to ride within fair view of it, but departed before we were within effective shotgun range.

\section{BALD EAGLE, Haliaeetus leucocephalus (Linn.)}

Though not noted by our party, the bald eagle was reported 
on Swan Lake near its head, by Mr. Leffingwell, who took a fine specimen there during our stay at the Station in the latter part of August. His accurate knowledge of this species warrants the including of the bald eagle in this list upon his identification.

360 a. DESERT SPARROW HAWK, Falco sparverious deserticolus Mearns.

This species did not appear to be as common near Sin-yalea-min Lake as elsewhere in its usual range. We noted it occasionally in our daily lists. In our ascent of Mt. Sin-yale-amin, this little falcon was seen at an altitude of 7,700 feet, pursued by five or six pine siskins. It was found regularly on the hillsides, though not abundantly, but was common everywhere over the prairies of the Reservation.

The sparrow hawk was not uncommon in the vicinity of Lake McDonald. It was noted most frequently near the outlet of the lake, and along the cliff on the eastern shore. No specimens were taken here. A small butte near our camp at Crow Creek was used as a sort of watch tower by the sparrow hawks, and generally several would be flushed when we climbed to its rocky summit.

Abundant on the ranches near Flathead Lake, preferring the edges of the woods. It resorts to rail fences, flying from one station to another ahead of the observer; or from a watch tower in the top of isolated trees in the meadows it scans the subjacent ground for venturesome mice, grasshoppers, crickets, and similar prey.

\section{AMERICAN OSPREY, Pandion haliaetus carolinensis} (Gmel.)

The osprey was noted only occasionally in our daily lists at Sin-yale-a-min Iake. It is likely that a pair of ospreys inhabited the ravine leading to the little pond, for the specimens we noted were generally seen in that locality. The lake did not appear to he frequented to any extent by the osprey, though it certainly afforded a generous supply of fish, which forms almost the entire bill of fare of this species. The inlet and outlet of the lake, which are stocked abundantly with trout, doubtless offer easier larders than the deeper waters of the lake. 
Common at Flathead Lake, especially near the mouth of Pend d' Orielle River, Swan River, and Flathead River. A family had possession of a large nest at the top of a tall, naked stub near the river on the Helena Club grounds, (see Plate VIII.), and two specimens were taken from this family during our stay in August. The osprey was also found very commonly on Swan Lake, where we spent two days near the foot, August 20 and 21.

366. AMERICAN LONG-EARED OWL, Asio wilsonianus (Less.)

The long-eared owl, being more generally nocturnal in its habits than the other owls, is less frequently noted than others. Only one specimen was observed, which was in the dark swampwoods of the Jocko River at Selish.

373 e. ROCKY MOUNTAIN SCREECH OWL, Megascops asio maxwelliae (Ridgw.)

A specimen of this screech owl was taken on Post Creek, where it was shot from our camp as it was perched in a dead tree beside the creek, having begun its nocturnal foraging soon after dusk.

375 a. WESTERN HORNED OWL, Bubo virginianus subarticus (Hoy.)

This form of the great horned owl apears to be common in the parts of the Flathead region included in our itinerary. The dense woodland are peculiarly adapted to this powerful nocturnal marauder. It inanifests its presence more particularly in the fall and winter months, when many specimens are captured by the ranchers. The only individual of this species we saw at MeDonald Lake was taking an evening outing along the low shore near the outlet, resting occasionally on the summit of some tall stub ere continuing his perambulations.

The western horned owl was reported as common along Crow Creek, though we did not take any specimens. The abundance of food would imply its presence. For some reason the Raptores, which we expected to find at this station, seemed less common than usual. 
On June 22, a specimen was seen at Estey's Pond. On August 6, a fine specimen was brought to the Station by $\mathrm{Mr}$. Estey, who reported the species very common on his ranch. No notes were made concerning its occurrence nearer the Station.

\section{BELTED KINGFISHER, Ceryle alcyon (Iinn.)}

The belted kingfisher is a common resident in summer along the shore of Sin-yale-a-min Lake. No specimens were taken, but were easily accessible, and were noted in all our daily lists. The clear waters of the lake furnished this avian fisher very attractive accommodations. By measurement it was found that we could see objects to the depth of thirty-five feet, and the schools of minnows playing near the shore were easy prey for the kingfisher. However, the kingfisher is not always successful in its dashes for its finny victim; in my opinion it fails more frequently than it succeeds. It always seizes its prey with its bill, and frequently finds it necessary to thrash its victim against a stake or branch before it can stow the morsel away in its gullet.

It was daily noted plying its vocation near the inlet of Lake McDonald. At the mouth of the inlet the fishing was particularly fine, and the fact that the water from the ravine above the lake entered the reservoir by several small mouths rendered the sport unusually excellent. It appeared that only one pair of kingfishers claimed the fishing rights of this lak. No specimens were taken.

The kingfisher was seen at all times near the Siation, frequenting the banks of Swan River near its mouth, and especially near the boat landing, where the shallower water afforded easier fishing grounds than the more turbulent flow of the river proper. This species was also found abundantly on Swan Lake, where we took several specimens while standing in our camp at the foot of the lake. Though we had reason to believe that there were no fish in Daphnia Pond, and few in Estey's Pond, the kingfisher was observed at both sta tions, and we concluded that the numerous frogs along the margins of the ponds offered the avian fisherman easier prer than the sport at Swan River. 
393 d. CABANIS'S WOODPECKER, Dryobates villosus hyloscopus (Cab.)

This species or form of the hairy woodpecker is not uncommon in the vicinity of Sin-yale-a-min Lake. Specimens were generally noted and one was taken. It is doubtless a permanent resident.

A specimen was noted visiting the large pine trees at our Crow Creek camp. It was not included in our list for the foot of Flathead Iake. Doubtless regularly found in the tall trees of the water-courses. Specimens were frequently taken near the Station at Flathead Lake.

394 b. BATCHELDER'S WOODPECKER, Dryobates pubescens oreoecus Batch.

The downy woodpecker in this Rocky Mountain form did not appear to be common in the immediate vicinity of Sinyale-a-min Lake. No specimens were taken, and those noted were more frequently heard than seen. More thorough examination of the locality might disclose its presence in greater proportion than our notes indicate. It is common in the vicinity of the Biological Station.

400. ARCTIC THREE-TOED WOODPECKER, Picoides arcticus (Swains.)

noted as commonly as the Alpine three-toed woodpecker.

A specimen was taken at Swan Lake, August 3, 1901.

401 b. ALPINE THREE-TOED WOODPECKER, Picoides americanus dorsalis Baird.

One specimen of this three-toed woodpecker, a young male, was taken in the woods north of the lake. The vigorous, deliberate, though intermittent tapping of this woodpecker is a pretty certain index of its presence near the observer; however, the wary nature of the woodland carpenter leads him to desist when the collector approaches his station. This specimen allowed me to walk past without my discovering him; but began his tapping immediately after my back was turned. Not uncommon near the mouth of Swan River. A specimen was taken in the woods east of the Club grounds, Aug. 16. 
402 a. RED-INAIEL SAPSUCKER, Sphyrapicus varius nuchatis Baird.

On the day of our arrival at Sin-yale-a-min Lake, and on the following day, a pair of red-naped sapsuckers claimed quarters alung the trail near our camp, and were frequently observed sporting on the tree-trunks, uttering their harsh calls as they flitted restlessly about their claimed domains. On the second day, a pariy of Indian campers stationed themselves near the plice, and used the trail for their racing and shooting frolics. The sapsuckers disappeared, and we made no further notes regarding the presence of this interesting species. Unlike other members of the woodpecker group, this sapsucker frequents the lower story of the woods, doubtless becruse of its fondness for the sap-laden inner fibers of the bark which it finds nearer the bases of the trunks. Its nesting site is also much lower or nearer the ground than the average of those of the other woodpeckers.

It is common in the woodlands in the vicinity of Lake McDonald. One specimen was taken, and it was regularly included in our daily lists. Its harsh, impatient call betokens its presence in any neighborhood, its noisy ways being decidedly in contrast with those of the three-toed woodpecker.

A pair of red-naped sapsuckers reared a brood in the weedy area in the swamp woods at the right of the mouth of Swan River, where specimens were frequently taken. Also frequently observed in the woods east of the Helena Club grounds. This species was apparently more frequently noted than either the Alpine three-tned woodpecker, Cabanis's woodpecker, or Batchelder's woodpecker, in the vicinity of the Station.

\section{PILEATED WOODPECKER, Ceophloeus pileatus (Linn.)}

The pileated woodpecker was not uncommon in the woods near the Station, and occasionally a specimen would even visit the Station grounds, uttering its loud flicker-like call from the top of one of the taller trees. On August 15 a specimen was taken in one of the trees on the western side of the grounds. This woodpecker was frequently heard in the swamp woods at the right of Swan River, and even more frequently in the Helena Club grounds at the left of the river. Two specimens were taken on August 2\% in the woods west of the road leading to Daphnia Pond. Both were tapping on medium-sized 
trunks, at points about half way up the boles. The shooting we had done in the woods during the preceding three weeks did not appear to have had any effect in frightening away this wary woodpecker from the old landmarks. However, the woodsman's axe will doubtless hasten this undesirable outcome.

This lordly inhabitant of the primeval woodlands is common in the vicinity of Sin-yale-a-min Lake. A pair had a home in the ravine leading westward from the lake. Their favorite haunts were tall denuded pines and tamaracks, though they were not often seen near the summits of the boles, apparently preferring: a middle station. Their loud, resounding tapping generally disclosed their presence, together with their loud, vibrant, flicker-like call. Our frequent shooting in the neighborhood and in the ravine where they made their headquarters did not seem to disturb them, though when we tried to stalk them they managed to keep out of range, silently flapping away when we aproached, so that no specimens were taken at this camp.

Likewise at MeDonald I Lake, after we had been in camp some days and had been shooting in the immediate neighborhood at all times during our stay, two specimens, an old female and a young male, were taken within a hundred yards of the camp.

\section{IEWIS'S WOODPECKER, Melanerpes torquatus (Wils.)}

This peculiar woodpecker was common in the woods near the outlet of Lake McDonald. It prefers the largest pines, from which it will fly out and capture an insect in air as expertly as a kingbird or other flycatcher, and return to its chosen station. There is a degree of wary secretiveness in its nature, however, for when an observer is near, it will remain silently lurking in the top of the tree until the patience of the observer is likely to be exhausted.

A pair were seen feeding young birds in a hole about fifty feet from the ground in a living pine, July 28, at Post Creek. This woodpecker was a common visitor to our camp at Crow Creek. We also noted it among the scrubby haw trees near our camp at the foot of Flathead Lake.

On the day of our first arrival at the Station, June 14, Lewis's woodpecker was a noticeable visitor to the Station grounds, and two specimens, which were making frequent sal- 
iies into the air from the tops of tall dead trees in quest of passing insects, were taken as a tribute to our curiosity in regard to this peculiar woodpecker. Upon our return to the Station, in the first week of August, Lewis's woodpecker was abundantly represented by specimens along the road leading toward Holt, where they would sit on the rail fences like crows or robins, each sitting quite upright and bunched together like an owl a-perch. On August 16 a specimen was taken that had one inner toe missing, which had apparently been severed close to the place of insertion. Around Daphnia Pond this woodpecker was also abundant, as well as at other stations in the neighborhood.

\section{RED-SHAFTED FLICKER, Colaptes cafer (Gmel.)}

This flicker is common everywhere in localities visited where trees of any size can be found. On one occasion at Sin-yalea-min Iake, three red-shafted flickers were observed flirting and coquetting at the top of a tall denuded stub. In our ascent of a ridge of Mt. MeDonald, this flicker was noted at an altitude of $\%, 700$ feet. It is the most common woodpecker in the vicinity of McDonald Lake. In the wooded localities in the open regions of the Reservation, the red-shafted flicker appears to be less numerously represented than the Lewis woodpecker.

420 a. WESTERN NIGHTHAWK, Chordeiles virginianus henryi (Cass.)

The western nighthawk was not common at Sin-yale-a-min Lake, though specimens were noted occasionally in twilight flight. No specimens were taken.

It was commonly seen flying about at nightfall at McDonald Lake. One specimen was taken as it was flying to and fro over the water at early dusk.

Abundant in the vicinity of Crow Creek. A small butte near our camp was a favorite haunt of the nighthawk, and from its top we secured several specimens at nightfall. We also found it abundant at the foot of Flathead Lake, and at the upper end as well, where it was found breeding. 
433. RUFOUS HUMMINGBIRD, Selasphorus rufus (Gmel.)

This hummingbird was a common visitor to our camp, and was noted regularly near the lakes. A female was taken while sitting on a naked branch near our tent, at McDonald Lake.

Very common in the vicinity of the Station. On the day of our arrival, a male rufous hummingbird was taken in the woods across the road from the Station, and others were noted. In the swampy woods between Swan and Flathead Rivers, this hummingbird was frequently observed darting at Traill's and other flycatchers, and pursuing them angrily for short distances, as though the latter were intruding upon its domains. Later in the season, August 11, a family was noted visiting the snowberry, a species of honeysuckle, and also feeding on the giant hyssop growing rankly beside the fences near the Station grounds.

\section{CALLIOPE HUMMINGBIRD, Stellula calliope Gould.}

The calliope hummingbird appeared to be common along the cliff east of MeDonald Lake. It was noted particularly in the vicinity of the waterfalls that dashed from the crevices of the cliff, where it would alight within a few feet of the observer, sitting on some dead twig to preen its plumage or rest after a journey along the rocky wall.

A family of calliope hummingbird was observed on the eastern side of the ridge east of the Helena Club grounds. Both elders and young were darting about from bush to bush, and apparently had one or two chosen stations for perching, generally bare twigs projecting from the periphery of a maple clump. The male parent bird was shot, and I had turned from picking him up, when another of the family was seen perched upon the same twig. No other specimens of this hummingbird were noted near the Station.

\section{KINGBIRD, Tyrannus tyrannus (Linn.)}

Abundant in the willows of Flathead Lake shore at the northern end, and also near Daphnia Pond. Nests were observed in the early season.

The kingbird was abundant along the streams of the reservation, and also along the foot of Flathead Lake. Many pairs were yet feeding young birds in the nest.

It was not observed at the smaller mountain lakes. 
44\%. ARKANSAS KINGBIRD, Tyrannus verticalis Say.

This noisy, handsome kingbird was abundant about the ranches of the Reservation. It is very noticeable in its movements and demonstrative in manners, having a short musical twitter which it utters generally upon alighting, accompanying the twitter with a fluttering or quivering movement of the wings. Like its congener the kingbird, it is very pugnacious in its disposition, chasing away the magpie or other invader of its domains. Its calls is vigorous in enunciation, resembling the syllable "ki". We noted it at Post Creek, Crow Creek, and at the foot of Flathead Lake, at all of which places it was manifestly prominent because of young birds lately upon the wing. The familiarity of this kingbird is measurably beyond that of Tyrannus tyrannus, as it will boldly establish itself in the midst of the busiest scenes. A pair had a nest on a crosspiece upon a telephone pole on Main Street in Missoula, on one of the busiest corners in the city. There the female would sit jauntily while people were hurrying along below her; and there the male would visit her with refreshing tid-bits regardless of the evidences of activity around their chosen domain.

\section{OLIVE-SIDED FLYCATCHER, Contopus borealis} (Swain.)

First observed on July 11, 1901, on the ridge leading to MacDougal Peak, at an altitude of 6,500 feet. A specimen was sitting in the bare top of a tall tree, uttering its harsh, querulous call. Though not then taken, it was readily identified by the white flank-tufts which show prominently between the wings and back when the bird is at rest. On August 10, 1901, a specimen was taken in the woods at the base of MacDougal Peak.

\section{WESTERN WOOD PEWEE, Contopus richardsonii (Swains.)}

This interesting species was common on the hillsides near the shores of the mountain lakes. Its sharp call, though suggestive of the plaint of the wood pewee of eastern regions, is quite different from the faraway-sounding call of the latter, being uttered in a more impatient, garrulous manner. The western species appears to 
prefer higher stations as its lookout, consequently seeking its food in a higher story of the forest than its eastern congener, and building its nest in sites higher in the trees. It generally chooses a station in a tall tree on a bare limb above the middle point, and there utters its sharp, querulous call, making occasional sallies into the air to capture passing insects. Trees on bushy hillsides are its most favored resorts.

\section{TRAILL'S FLYCATCHER, Empidonax traillii (Aud.)}

Common in the woods and bushy localities during August. It was not observed during our first visit to the Station. This flycatcher frequents a lower story than does the western wood pewee, being seldom observed higher than the middle of medium-sized trees, and usually preferring the clumps of maple and willow of fire-swept districts. It was most frequently noted in the woods between Swan River and Flathead River. Common near McDonald Lake.

469. WRIGHT'S FLYCATCHER, Empidonax wrightii Baird.

No specimens of this little flycatcher were taken at Sinyale-a-min Lake, but it appeared to be common on the hillsides south of the lake, where there was an extended growth of bushes and younger trees. There it could doubtless be found nesting in the breeding season, though no nests of the season were noted. In fact, it seemed that few birds had nester near this lake, judging by the absence of nests for the year. I am of the opinion that the lake is used by the birds more as a place for occasional resort than as a breeding ground.

Wright's flycatcher was found nesting in bushy localities near the Station, generally inhabiting the clumps of maple sprouts in the edges of the heavier woods or on ridges where former fires had prostrated the taller growth and given place to bushes. Four nests were found during the June collecting, but this flycatcher was not observed during our visit to the same localities in August.

474 c. DESERT HORNED LARK, Otocoris alpestris arenicola Hensh.

This horned lark was abundant on the prairie regions of the Reservation, and is doubtless the prevailing form in summer. 
The pallid horned lark, Otocoris alpestris leucolaema (Coues), is probably the prevailing winter form in Montana. The desert horned lark was found regularly from the base of Mt. McDonald to the shore of Flathead Lake, generally feeding along the roads, or flitting about in the vicinity of the pools. Most of the specimens taken were young of the year.

\section{AMERICAN MAGPIE, Pica pica hudsonica (Sab.)}

Abundant in the thickets of the foothills and along the streams; also in the dwarf trees along the shore of Flathead Lake. Many nests of the spring were noted, some high in the pines, though most of them were within reach without climbing, in dwarf haws and similar growth.

The magpie was not listed at Sin-yale-a-min Lake, but it was noted at McDonald Lake.

\section{8 c. BLACK-HEADED JAY, Cyanocitta stelleri annectens Baird.}

This mountain form of Steller's jay was quite common in the vicinity of Sin-yale-a-min and McDonald Lake. Such specimens as were wanted were taken, for they did not manifest a suspicious nature when the collector was near. All our specimens were in very poor plumage, undergoing the moult during our visit to the lake.

484 a. ROCKY MOUNTAIN JAY, Perisoreus cannadensis capitalis Ridgw.

The Canada jay in its Rocky Mountain form did not seem to be common near our itinerary. One specimen was taken at Sin-yale-a-min Lake while lurking in a fir clump near where we were sitting, on the southern shore of the lake; its curiosity perhaps led it to betray its presence. No other notes were made regarding its occurrence.

486. AMERICAN RAVEN, Corvus corax sinuatus (Wagl.)

A family of this species had a home up the hillside on the western shore of McDonald Lake. The noisy croakings were heard throughout our visit, and the birds were frequently 
seen flying over the lake. Several unsuccessful attempts were made to secure specimens. The American raven appears to be generally distributed over the Flathead region.

It was represented near the Station by a pair that frequented the swampy woods at the right of the mouth of Swan River. These were noted regularly when we visited the locality named, and frequent efforts were made to capture one, but the wary creatures invariably kept well beyond shotgun range, generally flying away with hoarse croakings to another part of their claimed domain when we entered the area anywhere near them.

488.

AMERICAN CROW, Corvus americanus Aud.

Not listed at Sin-yale-a-min Lake, but noted frequently in the woods near the inlet of McDonald Lake. On one occasion four or five were observed in a group in the tree-tops at the upper end of McDonald Lake.

It was regularly noted in our lists, both at Crow Creek and at the foot of Flathead Lake. It was most generally observed in the vicinity of the water-courses, where the fringing trees offered more congenial resorts than the bare prairies of the intermediate areas.

The American crow occurs only occasionally near the Station. On June 30, one was seen flying over the station grounds. No other notes were made concerning its occurrence in the vicinity of the Station.

\section{CLARKE'S NUTCRACKER, Nucifraga columbiana (Wils.)}

No specimens of Clarke's nutcracker were seen except in our ascent of the peak near Sin-yale-a-min Mountain, when the first nutcrackers were noted at an altitude of 4,700 feet; thence they were observed while we were in the timber, which ceased at an elevation of 7,700 feet, owing to the bare, rocky character of the ridge forming the higher regions of the mountain. The hillsides surrounding the lake are probably congenial resorts of the nutcracker, but as our observations were practically confined to the immediate margins of the lake, no other record concerning this species was made.

\section{BOBOLINK, Dolichonyx oryzivorus (Linn.)}

A troop of bobolinks visited our camp at Crow Creek, doubt- 
less attracted by the shorn .grainfields and meadows near the stream. Their metallic "clink" revealed their presence, and several specimens were taken. They are likely quite common in the creek bottoms in the fall migration. The bobolink of this region is now placed in the subspecies albinucha.

\section{COWBIRD, Molothrus ater (Bodd.)}

The cowbird was only occasionally noted in our lists, and then only at Crow Creek and the foot of Flathead Lake. One specimen, a young of the year, was taken at our camp at the outlet of Flathead Lake. This species seems to occur in smaller ratio in this region than might be fancied from knowledge of its wide distribution.

498.

\section{RED-WINGED}

\section{BLACKBIRD, Agelaius phoeniceus (Linn.)}

Common at suitable places near the head of Flathead Lake. It was found nesting in the reeds at Daphnia Pond, where a small colony had established itself. Very few specimens were seen near the pond in August.

501 b. WESTERN MEADOWLARK, Sturnella magna neglecta (Aud.)

This meadowlark was abundant in the prairie regions, especially in the neighborhood of the ranches and water-courses, everywhere from the foothills to the shore of Flathead Lake. It was most abundant near the stubble fields in the vicinity of the lake.

\section{BULLOCK'S ORIOLE, Icterus bullocki (Swains.)}

We found Bullock's oriole common in the groves at the foot of Flathead Lake. Nests of the year were observed, and several specimens of adult birds were taken.

510. BREWER'S BLACKBIRD, Scolecophagus cyanocephalus (Wagl.)

Abundant everywhere in the vicinity of the ranches and 
water-courses. Flocks were forming for summer feeding and fall migration, and were much in evidence near the lake shore.

\section{4 a. WESTERN EVENING GROSBEAK, Coccothraustes vespertinus montanus (Ridgw.)}

Comparatively common in the vicinity of Swan River and Flathead Piver, in the swampy woods. Specimens were seen and heard every day during our visit in June, and it is very probable that it nests in the locality, though no evidence of such nesting was observed. Specimens were frequently taken, both in June and in August. The fruit ranches in the vicinity of the woods mentioned appear to offer unusual attractions to the birds of the neighborhood; our first specimen of this grosbeak was taken as it was being allured by the store of raspberries at hand. The call of this species is closely imitative of that of a young chicken; if intensified and greatly increased in volume it would resemble the cry of the osprey.

This handsome bird was common along Crow Creek, where a specimen was taken immediately upon our arrival, before our camp was established. The tall pines in the neighborhood were regular stations for this grosbeak, and frequently a troop of six or eight would take possession of a treetop and chirp cheerily for a few minutes. It is not likely that the grosbeak is found far from the streamsides in the prairie region of the Reservation, as trees and thickets are its usual resorts.

518. CASSIN'S PURPLE FINCH, Carpodacus cassini Baird.

This purple finch does not appear to be common in the Flathead Lake region. A male was taken at Swan Lake on August 3, 1901. It was resorting to the grounds around an unoccupied cabin, associating with pine siskins in gleaning from the dooryard. Only one specimen was seen.

\section{AMERICAN CROSSBILL, Loxia curvirostra minor (Brehm)}

Along the immediate shore of Sin-yale-a-min Lake, the crossbills were not often noted; but around the pond mentioned as being southeast of the lake, the American crossbills were abundant, frequenting the tops of the tall trees in small flocks, 
and announcing their presence by their sharp chirps. Both adult specimens and young of the year were taken, always from the summits of the loftiest trees.

The American crossbill was regularly noted at Crow Creek and at the foot of Flathead Lake. Like the evening grosbeak, it is partial to the streamsides in the prairie regions, moving restlessly from place to place in troops of small numbers, and chirping merrily from the treetops.

It is common in the vicinity of the Station, frequenting the tops of the tall trees in small flocks, uttering short, sharp metallic chirps. It generally associates with the pine siskin and other frequenters of the upper story of the woods. It is represented more numerously in the fall, and during the latter part of August we found it abundant in the neighborhood of Daphnia Pond and Estey's Pond, moving about capriciously from one treetop to another and chattering its enjoyment in the liberty of its wildwood domain.

\section{PINE SISKIN, Spinus pinus (Wils.)}

The pine siskin was commonly seen in the tops of the tallest trees, though at Sin-yale-a-min Lake and McDonald Lake it is more generally heard passing overhead, uttering its goldfinchlike call, or chirping vigorously to its fellows. It is a social creature, and its familiarity will lead it to alight in the midst of the camp to glean refuse from the tables. The only specimen taken at Sin-yale-a-min Lake was shot in camp while it was picking up morsels of food near the cooking-tent.

This animated resident of the higher woodlands was abundant near the Station. During our visit in June, the pine siskin was one of the most noticeable birds of the neighborhood, flitting in sportive enjoyment among the treetops, and uttering a loud sibilant chirping as it bounded from tree to tree. Frequently specimens visited our camp and alighted at the door of our tent, to glean from the refuse of the table, manifesting all the familiarity of the chipping sparrow. One evening about sunset, while I was exploring the woods on the Helena Club grounds, a nest in the top of a small fir tree caught my attention. Giving the tree a vigorous shake to alarm any occupant of the nest. I was surprised to see a brood or flock of pine siskins, five or six in number, flutter out of the nest and away from the neighborhood, chattering with lively scolding at being thus rudely routed from their home. 
The pine siskin is commoner up the mountain slopes than near the lake shore. We noted it at all elevations up to 9,200 feet. Its call is so much like the plaintive "pee" of the goldfinch, which it also closely resembles in appearance except when the latter is in nuptial plumage, that one unacquainted with the pine siskin might fail to notice it as a different species. The young of the year appear to show brighter yellow in their plumage than the elders, which further adds to its likeness to the goldfinch.

In August the pine siskins were observed clinging to the heads of the giant hyssop, which grew extensively along the roadsides near the Station. A small flock would thus congregate in a patch of the hyssop, feeding from the heads in the manner of goldfinches, the resemblance being increased by the bright colors of some of the young of the year and by the goldfinch-like chirps of the pine siskins. The horse mint, Monarda fistulosa, was also a favorite food of this species.

540 a.

WESTERN VESPER SPARROW, Poocaetes gramineus confinis Baird.

This vesper sparrow occurs abundantly throughout the prairie regions of the Reservation. It frequents the grainfields and margins of the ranches in numbers, and is especially noticeable near the lake shore, where it visits the water's edge to refresh itself from the heat of the summer afternoons. Near the lake it appeared to be almost as numerous as Brewer's blackbird, at the time of our visit.

\section{6 a. WESTERN GRASSHOPPER SPARROW, Ammod- ramus savannarum perpallidus (Coues.)}

This sparrow was found to be common on the prairie localities of the Reservation, and several specimens were taken for identification. The males would frequently sit on a post of the rail fences and utter their queer songs, and also emit a sharp stridulating chirp or call, scarcely regarding our presence.

560 a. WESTERN CHIPPING SPARROW, Spizella socialis arizonae Coues.

The western chipping sparrow was found abundantly everywhere throughout our travels in the Flathead Reservation. 
Everywhere we found it the same unsuspecting, social character, industriously caring for the wants of its younglings. It prefers the bushes and smaller trees for its resorts, and like the pine siskin, will frequently enter the camp in quest of morsels of food.

On August 24, the chipping sparrow was noted in flocks of twenty-five to thirty, near the borders of the ranches in the vicinity of the Station, probably preparatory to migration.

$56 \%$ b. SHUFELDT'S JUNCO, Junco hyemalis slufeldti Coale.

This mountain form of the slate-colored junco is abundant in the vicinity of Sin-yale-a-min Lake and on Mt. McDonald to an altitude of 7,500 feet. It undoubtedly breeds in the neighborhood, as several specimens were taken while carrying food evidently for young birds. On one occasion the writer was convinced of the existence of a nest of this junco near a fallen log and adjacent brush, and searched closely for it, but was unable to discover it. The rattling ditty of the junco was heard regularly in the woods near Sin-yale-a-min Lake, a performance quite similar to that of the chipping sparrow, though uttered with more force and less rapid enunciation.

The junco is common on the wooded ridges near the Station, and undoubtedly breeds there. On June 20, a female was observed carrying food, and chirping anxiously at our presence, as if she had a nest or dependent young in the immediate neighborhood, but search for the nest was unavailing.

\section{1 b. MOUNTAIN SONG SPARROW, Melospiza fasciata montana Hensh.}

Common along the margins of Crow Creek. It was still in song, in accordance with its usual habit of singing throughout its entire summer residence. Several specimens were taken in the coverts near the water. The song sparrow was not noted at the foot of Flathead Lake, nor at the other lakes in the Mission Range.

The song sparrow was common in the brushy borders of the lake near the Station; also in the shrubbery along Daphnia Pond. Its melodious cadenzas were regularly heard in suitable surroundings, and specimens were frequently taken. 
583. LINCOLN'S SPARROW, Melospiza lincolnii (Aud.)

This sparrow was not infrequently noted near the Station. A specimen was taken on July 3 , from a troop of three flitting among the bushes along the road bordering the Station grounds.

\section{SWAMP SPARROW, Melospiza georgiana (Lath.)}

Though far to the westward of its regular range, a specimen was taken on August 11, in the bushes along the road bordering the Station grounds, that seemed to be no other than an undoubted swamp sparrow. It was in company with several other sparrows, apparently of the same species, but only one was secured. If the identification is correct, it will perhaps establish a record for the western range of the species.

\section{5 c. SLATE-COLORED SPARROW, Passerella iliaca schistacea (Baird.)}

This sparrow was found at our camp near Echo Lake, on July 12, where the loud, clear song of the males was heard in the vicinity of a small slough. Later a male yet in song was seen feeding young, and on the following morning a singing male was taken in the bushes bordering a small stream flowing through the slough. The slate-colored sparrow was not heard or seen elsewhere on our itinerary.

\section{ARCTIC TOWHEE, Pipilo maculatus arcticus (Swains.)}

Not uncommon near the Station in the shrubbery of the hillsides surrounding the ponds. It was noted regularly in the vicinity of Daphnia Pond, but was not observed generally in our collecting near the Station.

This towhee was common in the bushes of the mountainsides in the vicinity of McDonald Lake. Specimens of adults and young in first plumage were taken.

596. BLACK-HEADED GROSBEAK, Habia melanocephalı (Swains.)

No specimens of the black-headed grosbeak were taken or noted along the shore of Sin-yale-a-min Lake, but this species appeared to be common in the vicinity of the pond southeast of 
the lake, and there its rich notes could be heard in the warm July afternoons. On our visits to the pond we always observed it in the higher trees, though elsewhere it manifests a preference for the smaller and dwarf trees. However, when away from the immediate vicinity of its nest, it generally rises to a higher level to enunciate its song or to glean for its insect fare. We found it still in song at McDonald Lake.

Its singing was one of the enjoyable features of the swamp woods during our June visit to the Station, and upon our return in August it still regaled us with its melody as late as the 12th. The song is almost an exact counterpart of the rich performance of the rose-breasted grosbeak, which the blackheaded grosbeak also greatly resembles in habits. Several nests were found in June.

\section{LAZULI BUNTING, Passerina amoena (Say.)}

Common in the shrubbery of the bushy hillsides and ridges. It was found nesting in June. Its song is very much like that of its congener, the indigo bunting, so that a person familiar with the eastern species will readily recognize the lazuli bunting by the likeness of its musical performance to that of its relative.

\section{0\%. LOUISIANA TANAGER, Piranga ludoviciana (Wils.)}

The Louisiana tanager is one of the commonest birds of the vicinity of Sin-yale-a-min and McDonald Lakes. It was seen and heard daily in our observations, and such specimens as were needed were taken. Its chirping whistle is a familiar feature of the evergreen woods, and its brilliant livery is in noticeable contrast to the sombre regions it inhabits.

It is abundant everywhere in the woods near the Station. Its song so closely resembles that of the robin that the differ. ence is not readily detected except when both are performing within hearing. It breeds regularly in the neighborhood, nesting in June. In August the Louisiana tanager was observed feeding on the raspberries of the fruit ranches near the Station. On August 20 we noted that the tanager was no longer observed in our daily collecting, and it is likely that it departs rather early for its southern winter-quarters. 
612. CLIFF SWALLOW, Petrochelidon lunifrons (Say.)

This swallow was regularly noted near the creeks, where ranch buildings furnished it sites for its bottle-shaped mud homes. At the foot of Flathead Lake it was represented by a colony at Polson, and specimens were a-wing at all hours of the day, coursing over the meadows near the shore and above the haw groves in quest of the insects that swarmed the trees and ripened fruit.

\section{BARN SWALLOW, Chelidon eryihrogastra (Bodd.)}

Small colonies of the barn swallow were noted at St. Ignatius, Ronan, and other settlements of the Reservation.

\section{TREE SWALLOW, Tachycineta bicolor (Vieill.)}

Small colonies of the tree swallow are found at suitable localities at Polson and near the Station. Valleys between hillsides denuded by former fires, where tall boles and bare spires are standing, are generally inhabited by this swallow, as well as the margins of ponds where naked dead trees are found. It was found nesting at the Cedar Islands, in McGovern's Bay, in cavities of the decaying cedars.

\section{BANK SWALLOW, Clivicola riparia (Linn.)}

The bank swallow was regularly noted at suitable places in our travels through the Reservation, mingling with the cliff swallow in aerial evolutions above the meadows and the water in about equal numbers. It was observed at Crow Creek and also at the foot of Flathead Lake.

This swallow breeds regularly in the vicinity of the Station, and the graceful aerial movements of the bird a-wing generally called attention to the presence of the species in the neighborhood. Specimens were regularly seen near the buildings of ranches, and near a house the only bank swallow taken, for positive identification, was shot as it flitted over the road with others in its restless pursuit of food and pleasure.

\section{CEDAR WAXWING, Ampetis cedrorum (Vieill.)}

This handsome bird, though lacking the power of song by which many of our avian friends call attention to their pres- 
ence, was seen and noted in all our daily lists. Near the pond in the vicinity of Sin-yale-a-min Lake, this waxwing was very common, for above the stagnant water it found the hovering insects that furnished it a plentiful larder. Though the cedar waxwing has only the well-known lisping note with which to express all the scale of its avian emotions, it can vary its utterances of this feeble call to a considerable degree, even to such an extent that it sounds like another note.

The species was abundant in occurrence at the Crow Creek station and at the foot of Flathead Lake. At the latter place it was resorting to the haw thickets, where it feasted on the swarming insects, catching them among the branches in true warbler-like manner, and lisping its pleasure in the bounteous banquet spread for it by Mother Nature.

The cedar waxwing was found nesting in June at the Cedar Islands and in the woods adjacent to the Station grounds. At times it alights on oblique stems of low bushes, flies outward to capture passing insects, and returns to a similar station, acting greatly like a small flycatcher such as Traill's. On August 18 a cedar waxwing was taken which had the bill destroyed except the bases, as though the mandibles had been amputated while the bird was yet in the nest. The waxwing is very fond of black haw berries; it will generally swallow two or three berries, and then fly away with another in its bill. Between August 22 and 2\%, a medium-sized haw tree heavily laden with fruit was completely stripped by the waxwing, with the assistance of a half dozen western robins. Later in August the cedar waxwing was observed feeding on elder berries.

\section{RED-EYED VIREO, Vireo olivaceus (Linn.)}

Everywhere in our travels we noted the red-eyed vireo as quite common. Regularly we heard its emphatic monitorial song, and caught frequent glimpses of the performer as he gleaned industriously among the foliage near the branches which supported him. During our stay at Sin-yale-a-min Lake, the young vireos recently from the nest were claiming the attention of the parent birds, and upon hearing the harsh "gay" of the elder, we knew that one or more youngsters were crouched in the foliage nearby waiting for some dainty tidbit from the fond parent. This vireo breeds abundantly in the vicinity of the Station. 
62\%. WARBLING VIREO, Vireo gilvus (Vieill.)

The warbling vireo was found regularly in all localities under consideration. Like the red-eyed vireo, it breeds abundantly in the Flathead region. The charming song of this vireo, which is not interrupted until the author takes its departure for its winter home, enlivened the bushy woods near the lake, and frequently regaled the ear of the collector when all other songs had been hushed by the mid-afternoon heat. It is interesting to watch this songster as it warbles forth its ditty while engaged earnestly in seeking its insect food, seldom lifting its head from its task, singing as it works.

\section{YELLOW WARBLER Dendroica aestiva (Gmel.)}

The yellow warbler was found abundantly in the haw thickets at the lower end of Flathead Lake, where its song was still heard, and its movements observed as it flashed among the branches in its active pursuit of insect fare. We also noted its common occurrence at Crow Creek, in the thickets fringing the streamside.

It is abundant in the swamp woods between Swan River and Flathead River, nesting regularly in the breeding season.

\section{AUDUBON'S WARBLER, Dendroica auduboni (Towns.)}

This handsome warbler was found to be common in the region under consideration. The clear, ringing songs of the males were regularly heard in the earlier part of the season, uttered from the middle and upper stories of the taller evergreens. It was observed on the sides of Mt. MeDonald to $\%, 500$ feet elevation.

Common everywhere near the Station in the higher woods, and nesting regularly in the earlier season. Very common in the woods in middle August, when the fall migration probably begins. In a day's collecting at Estey's Pond, August 2\%, the most active bird of the surrounding woodland was Audubon's warbler, and several specimens of adults and young of the year were taken by accident beyond what we needed, from difficulty in identifying them in the tall trees which they generally prefer. 
668. TOWNSEND'S WARBLER, Dendroica townsendi (Towns.)

Whenever we entered a particular clump of small firs and bushes at Sin-yale-a-min Lake, a Townsend's warbler would appear and manifest great anxiety by chirping in nearby shrubbery. The place was searched repeatedly for evidences of nesting, but without avail. It is likely that the parent bird was feeding a youngster in the thicket, for before the end of our stay in the neighborhood the warbler had disappeared. We noted one or two other instances of the occurrence of this warbler at this camp.

Townsend's warbler was noted only occasionally in our collecting at the head of Flathead Lake. A specimen was taken August 6, on the Helena Club grounds, opposite the Station across the river, and an occasional note made thereafter regarding its presence in the woods in the neighborhood. It was generally observed in a lower story of the woodland than Audubon's warbler, frequenting about the same level as the smaller flycatchers or the yellow warbler.

\section{MACGILLIVRAY'S WARBLER, Geothlypis macgilli- vrayi (Aud.)}

Not uncommon near the Station, where it was found breeding in June, though only one nest was noted. Specimens were taken frequently in the woods during our August collecting. This warbler is a bird of the bushes, like the yellow-throat, but prefers bushes in low woodland to bushes near water. It was frequently noted in our lists at Sin-yale-a-min Lake; and a family just from the nest was found at McDonald Lake.

\section{1 a. WESTERN YELLOW-THROAT, Geothlypis trichas occidentalis Brewst.}

This yellow-throat was not uncommon in the bushes along Crow Creek, where its song was heard and specimens were taken. It was also frequently noted in the shrubbery near our camp at the foot of Flathead Lake, bordering the haw thickets.

Common in the bushes and weeds of Daphnia Pond, where it undoubtedly breeds, as it was regularly noted there both during June and August. It was also frequently observed in the bushes near the boat landing, in August. 
683 a. LONG-TAILED CHAT, Icteria virens longicauda (Lawr.)

This western form of the chat was abundant in the bushy localities near the Jocko River at Selish. Apparently the nesting season was just beginning, June 16, as the males were in full song and persistently voluble; but though the bushes were thoroughly searched, nothing was found but structures in the first stages of erection.

685. WILSON'S WARBLER, Sylvania pusilla (Wils.)

This warbler, regularly making its summer home north of the United States, sometimes lingers in the Rocky Mountain regions along its northward course, and rears its brood within our borders. One note was made of its occurrence along our itinerary, where it was found nesting at McDonald Lake, June 24, 1901.

68\%. AMERICAN REDSTART, Setophaga ruticilla (Linn.) - Abundant in all suitable localities near the Station. In June it was found nesting in numbers in the swamp woods between Swan River and Flathead River. Not frequently observed in the higher woods. Its songs were heard until the middle of August.

This species occurs commonly in the trees and shrubbery along the streamsides. We found it abundant at the foot of Flathead Lake, frequenting the haw groves and willows.

\section{AMERICAN DIPPER, Cinclus mexicanus Swains.}

Along the dashing waters of the falls above Sin-yale-a-min Lake the American dipper finds a congenial home. Its dark gray attire is quite in harmony with the rocks upon which it stands in the midst of the roaring rapids, as well as the sombre light of the thick forests which surround its chosen domains. Though we searched diligently among the rocks along the falls, we were unable to find a nest. The American diper was also observed along the outlet of the lake, where the little stream dashes among the boulders on its way down the ravine. We also noted it at the outlet of Lake McDonald.

The American dipper occurs not uncommonly along Swan River, between the head of the rapids and the mouth. Very likely breeds, as it was observed both in June and August. 


\section{CATBIRD, Galeoscoptes carotinensis (Linn.)}

We found several families of the catbird near our camp at Crow Creek, one nest containing three helpless young and an infertile egg. The low crooning of the catbird was frequently heard in the thickets, and occasionally the louder recitals at daybreak. At our camp near Polson we found it to be one of the common visitors to the haw thickets, and it is very probable that nests were in the adjacent shrubbery.

Regular summer residents near the Station. Nests were found on the Helena Club grounds and in the shrubbery bordering Daphnia Pond. No notes were made concerning its occurrence in August.

721 b. WESTERN HOUSE WREN, Troglodytes aedon aztecus Baird.

Not uncommon on bushy hillsides near the Station. It was regularly noted in June, and notes were made regarding its presence in August.

\section{ROCK WREN, Salpinctes obsoletus (Say.)}

The rock wren was regularly noted at Selish, where it inhabited the rocky mountain-side east of the Jocko River bottom. No specimen was taken.

\section{WINTER WREN, Troglodytes hiemalis Vieill.}

The dark shades of the arbor vitae forest at the head of Sinyale-a-min Lake, through which the inlet dashes in its tortuous course, is peculiarly suitable to the desires of the winter wren. There is whiles away its hours in happy content, pouring forth with astonishing persistency its little roundelay of song, and whirring from one side of the stream to the other at fancy's impulse. As in the case with the American dipper, we searched for a nest of this diminutive songster of the brookside. With equal result we tried to secure a specimen without its falling into the hurrying water. There is no doubt, however, that the winter wren is a regular summer resident at this place, rearing its young undisturbed by wandering collectors, and making melody unheard except by occasional visitors to the falls. 
Noted regularly in the thick woods along the inlet and outlet of Lake McDonald. It was still in song. As at Sin-yale-a-min, we were unable to secure a specimen without destroying or losing it in the hurrying water. This diminutive hermit of the arbor vitae forest is wonderfully expert in dodging observation, whisking in and out of the observer's view with provoking restlessness, and generally perching upon branches extending over the water.

\section{6 b. ROCKY MOUNTAIN CREEPER, Certhia familiaris montana Ridgw.}

The Rocky Mountain creeper was not uncommon in the woods near our various camps. It occasionally visited the adjacent trees, and was generally noted in our daily lists. Specimens were frequently taken on the grounds of the Biological Station.

72\% a. SLENDER-BILLED NUTHATCH, Sitta carolinensis aculeata (Cass.)

Common in the vicinity of the lakes and water-courses. Like the creeper, it frequently manifested its presence near our camp by its weak, penny-trumpet call.

728. RED-BREASTED NUTHATCH, Sitta canadensis Linn.

Quite common in the woods near the Station. On the first day of our return to the Station, a specimen of this nuthatch was taken on the Club grounds. We also noted its occurrence at Estey's Pond, and in all suitable localities included in our August collecting.

735 a. LONG-TAILED CHICKADEE, Parus atricapillus septentrionalis (Harris.)

Common throughout the Flathead region.

738. MOUNTAIN CHICKADEE, Parus gambeli Ridgw.

This handsome chickadee is doubtless a common resident of the mountainous regions in the vicinity of Flathead Lake, but 
it was not noted by us until Aug. 11, 1901, when a specimen was observed on MacDougal Peak, at an altitude of 6,500 feet. No other note was made regarding its occurrence.

748. GOLDEN-CROWNED KINGLET, Regulus satrapa Licht.

The golden-crowned kinglet was rather common in the mountainous woodlands of our itinerary, and undoubtedly breeds here, as it was noted regularly in the middle of June, always active in the tops of medium-sized evergreens and birches.

749. RUBY-CROWNED KINGLET, Regulus calendula (Linn.)

This diminutive inhabitant of the evergreen foliage was not uncommon in the wooded mountains. It was noted at Echo Lake, near MacDougal Peak, in the middle of July, several individuals generally associating in restless movements as they foraged among the trees fringing the water. One specimen was taken.

754. TOWNSEND'S SOLITAIRE, Myadestes townsendii - (Aud.)

A young of the year of this species was taken on the cliff at the lower end of McDonald Jake. The female parent bird was observed at the same time, but she was not secured. No other specimens of Townsend's solitaire were noted, but its calls were often heard near our camp.

756 a. WILLOW THRUSH, Turdus fuscescens salicicola (Ridgw.)

One nest was found in June, in the willow swamp between the two rivers. The female was taken with the nest. No other specimens were taken, or other notes made concerning its occurrence. Later it was found to be not uncommon in the willow swamp-woods.

758 a. OLIVE-BACKED THRUSH, Turdus ustulatus swainsonii (Cab.)

This thrush is common in the region near Sin- 
yale-a-min and McDonald Lakes. It did not appear to be nesting as commonly elserwhere as at Flat. head Lake, as no nests of the season were found. However, a nest was found along the trail beside Sin-yale-a-min Falls, on a horizontal branch directly above the head within reach of the hand, containing two eggs, July 11. The notes of the olive-backed thrush were regular features of the woods during our stay at Sin-yale-a-min.

Abundant in all localities near the Station, and breeding in numbers in June. Probably disappears from the neighborhood about the middle of Angust, as our last notes regarding its presence were made on August 9.

761 a. WESTERN ROBIN, Merula migratoria propinqua Ridgw.

We did not find the robin as common near Sin-yale-a-min Lake as might be fancied. With the exception of one family on the northern shore of the lake, we did not note the occurrence of this species. In this instance, the parents were feeding young still in the nest.

A nest was found on the cliff-side east of McDonald Lake in a clump of maple, with three eggs. The robin was observed visiting the water falls in the face of the cliff, to bathe and drink.

Abundant in the vicinity of the Station as a summer resident. In the second week of August, the robin was observed in small flocks of ten to twelve. During the last week of August, the robin was feeding greedily on the black haws, associating with the cedar waxwing at the plenteous banquet.

\section{MOUNTAIN BLUEBIRD, Sialia arctica Swains.}

Not common, but occasionally observed and noted in our lists.

A specimen was taken on Mt. McDonald at an elevation of 7,500 feet. 


\section{SUIMVIARY AND COINCLUSIOIN}

OIf the one hundred twenty-eight species included in the foregoing list, it is probable that at least eight are fall migrants, breeding in the far north and entering the United States early toward the close of summer. It is likely that the remaining one hundred twenty species breed in the Flathead Lake region or near the northern border of the state. At least thirty of the birds listed are permanent residents of the region; the others are summer residents only, spending the colder months in more southern localities.

In this connection it may not be amiss to make a brief statement of facts, gathered from the preceding notes, which are considered as worthy of special emphasis. The long-tailed chat, Icteria virens longicauda, according to the A. O. U. Check List of North American Birds, ranges north to southern Montana; our observations continue the northward range of this chat to beyond the middle line of the state, as we found it common at Selish in the middle of June. The note relating to the occurrence of the swamp sparrow, Melospiza georgiana, may require revision, as the specimen passed from the hands of the collector, who was unable to obtain authoritative identification; the skin is now in the University collection, and will receive careful attention in due time. The same statement applies to the specimen labeled western gull, Larus occidentalis, as there is a doubt regarding its identification. If authentic, it may denote an unusual eastern range for this gull.

The abundance of the western evening grosbeak in the vicinity of the Biological Station should be remarked. From the middle of July the characteristic chirp of this grosbeak was especially noticeable, and at that time parent birds were generally observed feeding young of the year in the trees near the station. There is no doubt that this grosbeak breeds plentifully in the neighborhood, and I am of the opinion that it nests later than is generally supposed, thus causing its nesting to be frequently overlooked.

In conclusion, the writer desires to thank the Director of the University of Montana Biological Station, Prof. M. J. Flrod for the excellent facilities afforded and the opportunity of a thorough study of the summer birds of the region under consideration; also to thank the President of the University of Montana, Dr. O. J. Craig, for the neat and artistic manner in which this report is presented for public distribution. 


\section{INDEX}

Accipiter

Page

cooperi

45,46

velox

$30,31,45$

Actitis macularia

$32,33,41,42$

Aegialitis vocifera $\ldots \ldots \ldots \ldots \ldots \ldots \ldots \ldots$

Agelaius phoeniceus

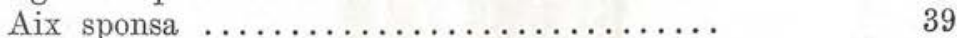

Ammodramus savannarum perpallidus...... Ampelis cedrorum

Anas

boschas

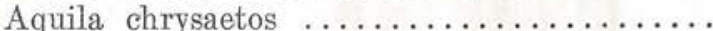

Archibuteo lagopus sancti-johannis.........

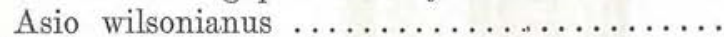

Bartramia longicauda

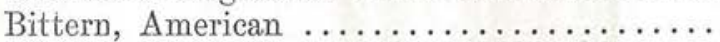

Blackbird

Brewer's

59,62

Red-winged

Bluebird, Mountain 58,59

Bobolink

Bob-white

Bonasa umbellus umbelloides...$\ldots \ldots \ldots \ldots$

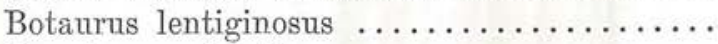

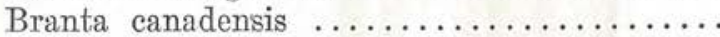

Bubo virginianus subarcticus ............ 48

Buffle-head ........................

Bunting

Indigo

24,65

Lazuli

\%, 24,65

Buteo borealis calurus ..................

46

Calidris arenaria $\ldots \ldots \ldots \ldots \ldots \ldots \ldots \ldots$

41

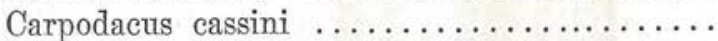

Catbird

60

Ceophloeus pileatus...$\ldots \ldots \ldots \ldots \ldots \ldots$

Certhia familiaris montana $\ldots \ldots \ldots \ldots \ldots$.

$6, \%, 13, \% 1$

51,52

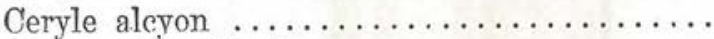

Charionetta albeola..$\ldots \ldots \ldots \ldots \ldots \ldots$.

Chat, Long-tailed. 
Chelidon erythrogastra $\ldots \ldots \ldots \ldots \ldots \ldots \ldots$

Chickadee

Long-tailed

Mountain

$34,7 \%$

72

Chordeiles virginianus henryi $\ldots \ldots \ldots \ldots \ldots$

$28,29,53$

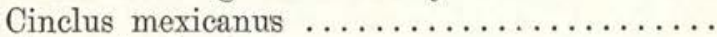

Circus hudsonius $\ldots \ldots \ldots \ldots \ldots \ldots \ldots \ldots$ $33,70,71$

45

Clivicola riparia $\ldots \ldots \ldots \ldots \ldots \ldots \ldots \ldots$

Coccothraustes vespertinus montanus ........

Coccyzus erythrophthalmus ..............

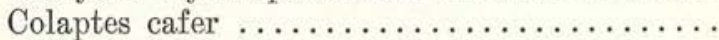

Colinus virginianus $\ldots \ldots \ldots \ldots \ldots \ldots \ldots \ldots$

Colymbus nigricollis californicus $\ldots \ldots \ldots \ldots$.

Contopus

borealis $\ldots \ldots \ldots \ldots \ldots \ldots \ldots \ldots \ldots$.

richardsonii $\ldots \ldots \ldots \ldots \ldots \ldots \ldots \ldots \ldots \ldots$

Corvus

americanus $\ldots \ldots \ldots \ldots \ldots \ldots \ldots \ldots \ldots$.

corax sinuatus . . . . . . . . . . . . . .

Cowbird

66

60,61

29,30

53

43

$3 \%$

55

55,56

Creeper, Rocky Mountain ................

Crossbill, American ............... 4,

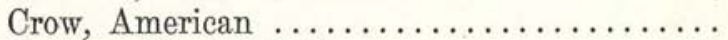

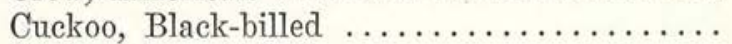

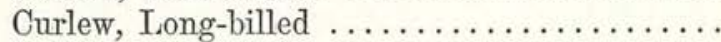

Cyanocitta stelleri annectens..$\ldots \ldots \ldots \ldots$.

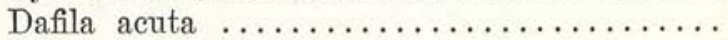

Dendragapus

franklini

obscurus richardsonii

Dendroica

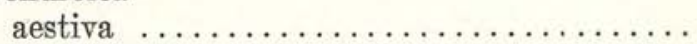

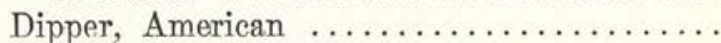

Dolichonyx oryzivorus

$3,33,70,71$

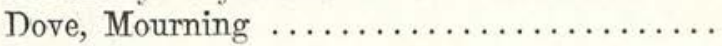
58

Dryobates pubescens oreoecus $\ldots \ldots \ldots \ldots \ldots \ldots \ldots . \ldots$ villosus hyloscopus $\ldots \ldots \ldots \ldots \ldots \ldots \ldots \ldots . \ldots$

Duck, Wood ...................... 39

Eagle 


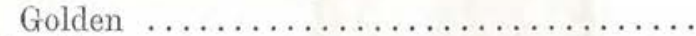

Empidonax

traillii $\ldots \ldots \ldots \ldots \ldots \ldots \ldots \ldots \ldots \ldots \ldots \ldots \ldots$

wrightii $\ldots \ldots \ldots \ldots \ldots \ldots \ldots \ldots \ldots \ldots \ldots \ldots \ldots$

Talco sparverius deserticolus . ......................... 47

Finch, Cassin's Purple .............. 60

Flicker

Golden-shafted. Erralum: read Red-shafted.

Red-shafted

8,53

Flycatcher

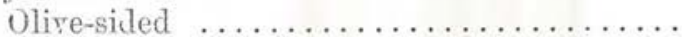

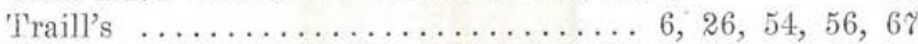

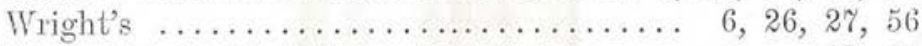

Galeoscoptes carolinensis $\ldots \ldots \ldots \ldots \ldots \ldots \ldots$ 13, $7_{1}$

Gallinago delicata ............... 41

Geothlypis

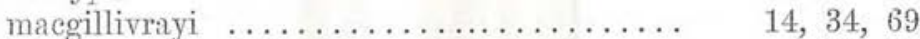

trichas occidentalis . . . . $\ldots \ldots \ldots \ldots \ldots$ 34, 69

Glancionetta clangula americana ....................... 39, 40

Golden-eye, American ............. \%, 36, 39, 40

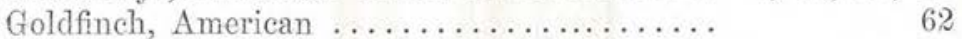

Goose, Canada .................... 49

Grebe

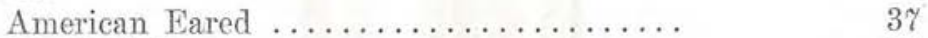

Pied-billed $\ldots \ldots \ldots \ldots \ldots \ldots \ldots \ldots \ldots \ldots \ldots$

Grosbeak

Black-headed $\ldots \ldots \ldots \ldots \ldots \ldots \ldots \ldots 6,24,25,64,65$

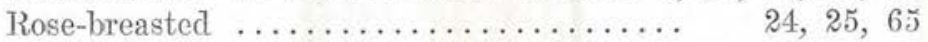

Western Evening ............6, 16, 60, 61, 75 Grouse

Columbian Sharp-tailed ............ 44

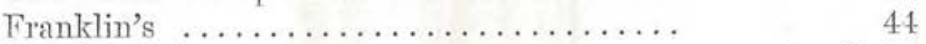

Gray Ruffed ................. 4, 6, 41

Richardson's ............... 4, 7, 43, 41 Gull

Ring-billed . . . . . . . $38 \ldots \ldots \ldots \ldots \ldots . \ldots \ldots$

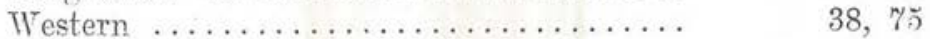

Habia melanocephala ......................... 24, 64

Haliaetus lencocephalus ........... 46

Hawk

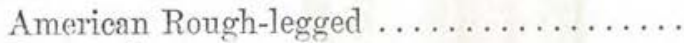

Desert Sparrow .................. 31, 4 y

Cooper's $\ldots \ldots \ldots \ldots \ldots \ldots \ldots \ldots \ldots \ldots \ldots \ldots \ldots$ 
Marsh

Sharp-shinned

Hummingbird

Calliope

$30,31,45$

Rufous

7,54

7, 36, 54

70,75

59

Icterns bullocki

Jay

Black-headed

4, $35,5 \%$

Rocky Mountain

4, $5 \%$

Junco, Shufeldt's ................ \%, 26, 35, 63

Killdeer ..........................

Kingbird $\ldots \ldots \ldots \ldots \ldots \ldots \ldots \ldots \%$, 22, 28, 36, 52, 54, 55

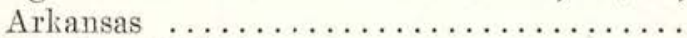

Kingfisher, Belted

$6, \quad 7,49$

Kinglet

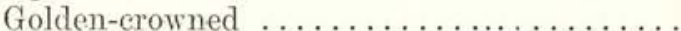

Ruby-crowned

Lark

Desert Horned ...................

Pallid Horned $\ldots \ldots \ldots \ldots \ldots \ldots \ldots \ldots \ldots$

Larus

delawarensis

occidentalis

Loon

Red-throated ..................... 38

Lophodytes cucullatus ................ 38

Loxia curvirostra minor $\ldots \ldots \ldots \ldots \ldots \ldots$.

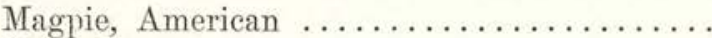

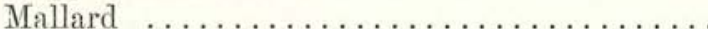

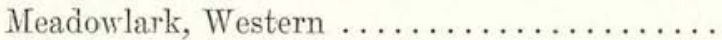

Megascops asio maxwelliae $. . . \ldots \ldots \ldots \ldots . . . .$.

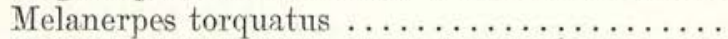

Melospiza

fasciata montana $\ldots \ldots \ldots \ldots \ldots \ldots \ldots$.

georgiana $\ldots \ldots \ldots \ldots \ldots \ldots \ldots \ldots \ldots \ldots$

lincolni

64,75

64

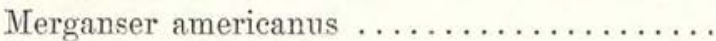

38

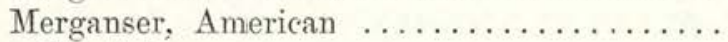

38,39

Hooded

38

Merula migratoria propinqua $\ldots \ldots \ldots \ldots \ldots$

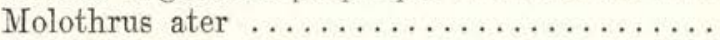

$9,23,74$

Myadestes townsendii 
Nighthawk, Western .................

Nucifraga columbiana $\ldots \ldots \ldots \ldots \ldots \ldots \ldots$.

Numenius longirostris $\ldots \ldots \ldots \ldots \ldots \ldots \ldots$.

Nutcracker, Clarke's ...................

Nuthatch

Red-breasted $\ldots \ldots \ldots \ldots \ldots \ldots \ldots \ldots \ldots \ldots \ldots \ldots \ldots$

Slender-billed $\ldots \ldots \ldots \ldots \ldots \ldots \ldots \ldots \ldots \ldots \ldots \ldots$

Oriole, Bullock's ................... 59

Osprey, American .............. 7, 30, 47, 48, 60

Otocoris alpestris arenicola $\ldots \ldots \ldots \ldots \ldots \ldots . \quad 56$

alpestris leucolaema $\ldots \ldots \ldots \ldots \ldots \ldots \ldots$.

Owl

American Long-eared ................ 48

Rocky Mountain Screech ............. 48

Western Horned .................. 8, 4.9

Pandion haliaetus carolinensis $\ldots \ldots \ldots \ldots \ldots . \quad 47$

Parus

atricapillus septentrionalis $\ldots \ldots \ldots \ldots \ldots \ldots \quad 7_{2}$

gambeli ......................

Passerella iliaca schistacea .............. 64

Passerina amoena .................. 24, 65

Pediocaetes phasianellus columbianus......... 44

Perisoreus canadensis capitalis $\ldots \ldots \ldots \ldots \ldots . .57$

Petrochelidon lunifrons $\ldots \ldots \ldots \ldots \ldots \ldots \ldots .66$

Pewee, Western Wood $\ldots \ldots \ldots \ldots \ldots \ldots \ldots$

Phalarope, Northern ................ 41

Phalaropus lobatus ................... 41

Pica pica hudsonica $\ldots \ldots \ldots \ldots \ldots \ldots \ldots \ldots \ldots$

Picoides

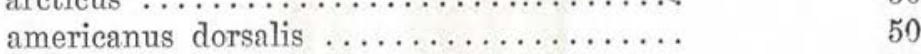

Pintail ........................ 39

Pipilo maculatus arcticus .............. 64

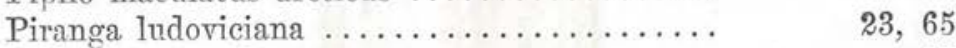

Podilymbus podiceps $\ldots \ldots \ldots \ldots \ldots \ldots \ldots \ldots . .37$

Poocaetes gramineus confinis $\ldots \ldots \ldots \ldots \ldots \ldots . \ldots 2$

Porzana carolina ..................... 40

Raven, American .............. 5, $7,57,58$

Redstart, American ............... 6, 13, 14, 17, 70

Red-tail, Western .................. 46

Regulus

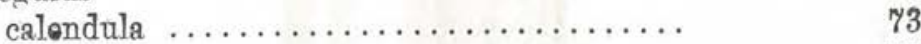

satrapa $\ldots \ldots \ldots \ldots \ldots \ldots \ldots \ldots \ldots \ldots \ldots \ldots \ldots$ 


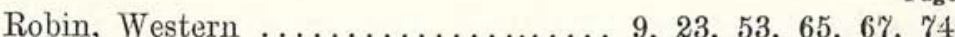

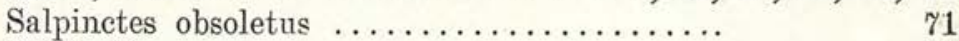

Sanderling $\ldots \ldots \ldots \ldots \ldots \ldots \ldots \ldots \ldots \ldots \ldots \ldots \ldots$

Sandpiper

Baird's ................... 41

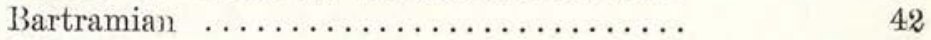

Solitary .................. 42

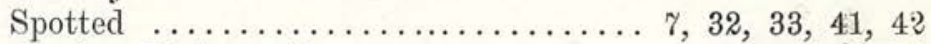

Sapsucker, Red-naped $\ldots \ldots \ldots \ldots \ldots \ldots \ldots$ 29, 51

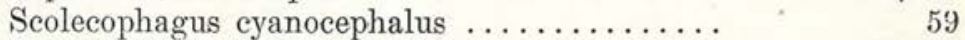

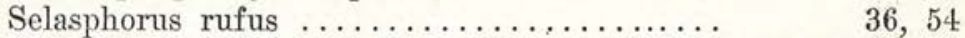

Setophaga ruticilla $\ldots \ldots \ldots \ldots \ldots \ldots \ldots \ldots \ldots \ldots$ 13, 17, 70

Sialia aretica $\ldots \ldots \ldots \ldots \ldots \ldots \ldots \ldots \ldots \ldots \ldots$

Siskin, Pine .......... $7,8,15,47,60,61,62,63$

Sitta

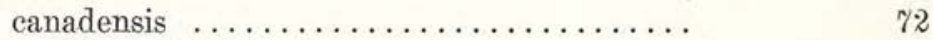

carolinensis aculeata $\ldots \ldots \ldots \ldots \ldots \ldots \ldots$

Snipe, Wilson's ..................... 41

Solitaire, Townsend's ............. 5, 73

Sora $\ldots \ldots \ldots \ldots \ldots \ldots \ldots \ldots \ldots \ldots \ldots \ldots \ldots \ldots \ldots \ldots \ldots, 16,40$

Sparrow

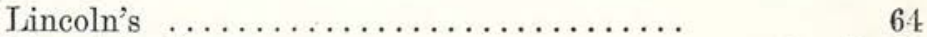

Mountain Song .................. 6, 7,63

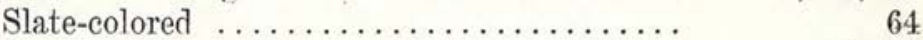

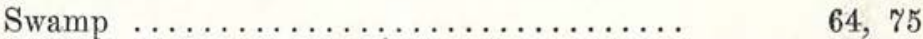

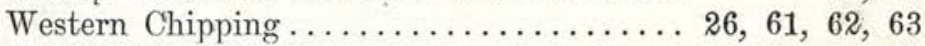

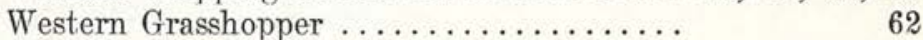

Western Vesper ................. 62

Sphyrapicus varius nuchalis .......... 29,51

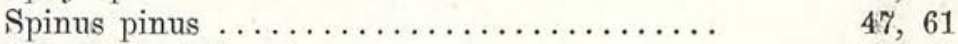

Spizella socialis arizonae $\ldots \ldots \ldots \ldots \ldots \ldots \ldots \quad 26,62$

Stellula calliope $\ldots \ldots \ldots \ldots \ldots \ldots \ldots \ldots \ldots \ldots$

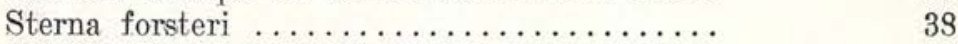

Sturnella magna neglecta $\ldots \ldots \ldots \ldots \ldots \ldots$

Swallow

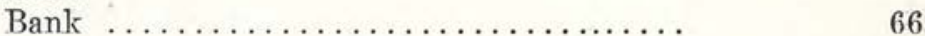

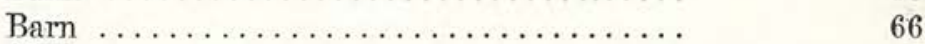

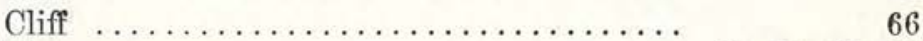

Tree $\ldots \ldots \ldots \ldots \ldots \ldots \ldots \ldots \ldots \ldots$ 8, 22, 23, 66

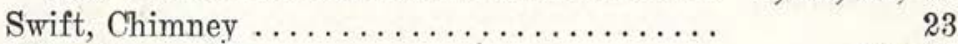

Sylvania pusilla $\ldots \ldots \ldots \ldots \ldots \ldots \ldots \ldots \ldots$

Tachycineta bicolor $\ldots \ldots \ldots \ldots \ldots \ldots \ldots \ldots$ 22, 23, 66

Tanager, Louisiana $\ldots \ldots \ldots \ldots \ldots \ldots \ldots \ldots \ldots \ldots \ldots$ 
Teal, Green-winged $\ldots \ldots \ldots \ldots \ldots \ldots \ldots \ldots$

Tern, Horster's ................ 38

Thrush

Olive-backed $\ldots \ldots \ldots \ldots 6,10,11,19,20,22,33,73,74$ Willow ................6, 12, 14, 33, 73

Totanus

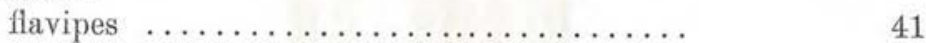

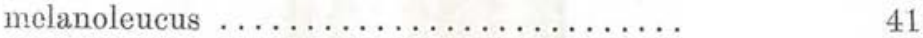

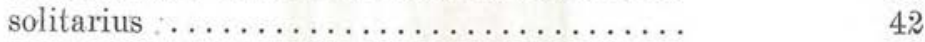

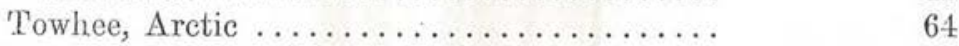

Tringa bairdii ................ 41

Troglodytes

hiemalis $\ldots \ldots \ldots \ldots \ldots \ldots \ldots \ldots \ldots \ldots \ldots$

Turdus

fuscescens salicicolus $\ldots \ldots \ldots \ldots \ldots \ldots \ldots$ 12, 14, 33, 73

ustulatus swainsoni $\ldots \ldots \ldots \ldots \ldots \ldots \ldots$ 10, 19, 33, 73

Tyrannus

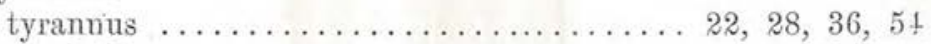

verticalis $\ldots \ldots \ldots \ldots \ldots \ldots \ldots \ldots \ldots \ldots \ldots \ldots \ldots$

Urinator

imber .................... 3 y

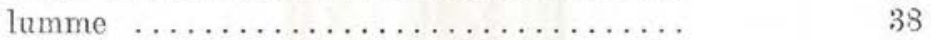

Vireo

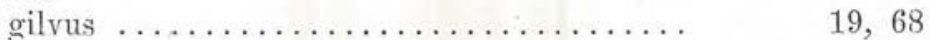

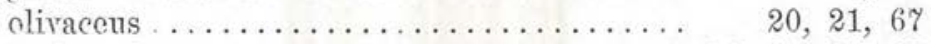

Red-eyed $\ldots \ldots \ldots \ldots \ldots \ldots \ldots \ldots \ldots$ 6, 20, 21, 67, 63

Warbling ..............6, 19, 20, 21, 68

Warbler

Audubon's $\ldots \ldots \ldots \ldots \ldots \ldots \ldots \ldots$ \% $15,1 \%, 68,69$

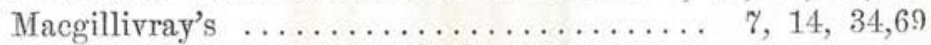

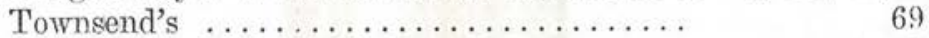

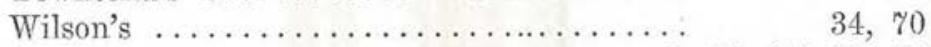

Yellow $\ldots \ldots \ldots \ldots \ldots \ldots \ldots \ldots, 17,27,68,69$

Waxwing, Cedar ............ 4, 22, 66, 67, 7 1

Woodpecker

Alpine Three-toed $\ldots \ldots \ldots \ldots \ldots \ldots \ldots \ldots \quad 7,50,51$

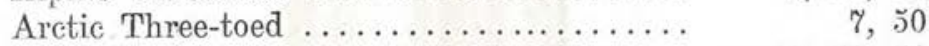

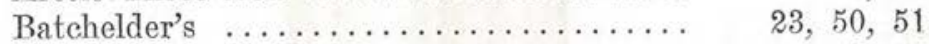

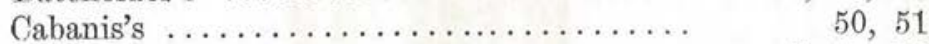

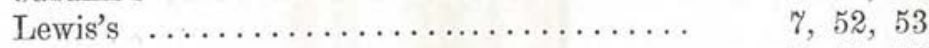

Pileated $\ldots \ldots \ldots \ldots \ldots \ldots \ldots \ldots \ldots \ldots \ldots \ldots \ldots \ldots$ 
Wren

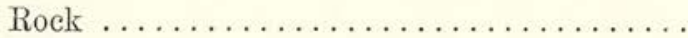

Western House

Winter $\ldots \ldots \ldots \ldots \ldots \ldots \ldots \ldots \ldots \ldots \ldots \ldots$

Yellow-legs

Greater

Yellow-throat, Western $\ldots \ldots \ldots \ldots \ldots \ldots 6$, \%, 15, 34, 69

Zenaida macroura .................. 



\title{
FOURTH ANNUAL SESSION \\ University of Montana Biological Station FLATHEAD LAKE.
}

\author{
Postoffice, Bigfork, Flathead Co., Montana.
}

The laboratory work of the Station will open Monday, July 14, and continue five weeks, or until Saturday, Aug. 16.

For a week or ten days before the Station opens and for two or three weeks after the work closes some one of the Station staff will be at or near the Station, and will aid any who may choose to work during such time. The laboratory is at the disposal of students, if it is wanted, from June 15 to September 1 st.

\section{STAFF OF INSTRUCTORS.}

Oscar J. Craig, President of the University.

Morton J. Elrod, Prof. of Biology, University of Montana, Director of the Station, General Zoology.

P. M. Silloway, Principal Fergus County High School, Ornithology, Elementary Botany.

Maurice Ricker, Principal Burlington, (Iowa), High School, Nature Study, Plankton.

Harry N. Whitford, Assistant in Botany, University of Chicago, Forest Ecology.

Mrs. Edith Ricker, Station Artist.

\section{ORGANIZATION.}

The Biological Station of the University of Montana was established in 1899 , for the purpose of offering to the students of the University and to the teachers and students of the State an opportunity for study, collection, investigation and recreation during the summer. By providing the best facilities the state can afford, and making the instruction free to all, the summer work at the Station presents exceptional opportunfties for study, and every encouragement is given to those attending to have both a pleasant and a profitable time. The situation of the Station on the largest fresh water lake in the Northwest makes possible a study of inland and cold water life not presented at any other locality.

\section{LOCATION.}

The field laboratory is located on the bank of Swan River at its outlet into Flathead Lake. This location affords a fine harbor for boats and a good camping site for the tents of those attending. The adjacent. region contains forests, ponds, lakes, swamps, cultivated fields, mountains, rivers and ravines. It is rich in animal and vegetable life. The lake offers rare opportunities for collecting, and presents some beautiful scenery. Elast of the lake the Mission range comes abruptly to the water's edge. The range slopes from the Swan river on the north to the high peaks, ten thousand feet, at the southern end, and its scenery is wild, rugged and grand, truly Alpine in character, and rivaling the Alps in beauty and magnificence. West of the lake are the Cabinets. Near the Station Swan lake, Rost lake, Echo lake, and other waters, are easily accessible. Daphnia pond , a few minutes walk from the Station, is rich in pond life, while Estey's pond, about as far again, is fully as productive.

\section{EQUIPMENT.}

The Station is in possession of three boats for use of students; a gasoline launch, Missoula; a 16-foot wood row boat, Culex; and a 14-foot canvas boat, Daphnia; the latter for use when it is necessary to transport a boat. The building is a convenient out-door laboratory, with tables for a dozen students. There is a dark room for photography. Microscopes, glassware, books, and utensils will be supplied from the University.

Botanical material, insect nets, pumping apparatus, and other collecting paraphernalia will be supplied. 
Students in Ornithology must supply their own guns. Necessary ammunition will be supplied. Students in Photography will furnish their own cameras and plates. The necessary chemicals for development will be supplied. Students who live in tents will supply their own tents and bedding.

\section{COURSE OF STUDY.}

Zoology:

(a) Laboratory and field work, including dissection or microscopic study of type forms, with field work and instruction in collecting and preserving for laboratory use and permanent collections. Prof. Elrod.

(b) Field and laboratory course in entomology. Instruction in collecting, preserving and labelling insects. Dissection and study of type specimens. Prof. Elrod.

(c) A course in plankton methods. Collecting of microscopic organism, determination of quantity, examination of material. Prin. Ricker.

(d) Ornithology. A study of birds, with methods of collecting, making and preserving skins; habits and lives of birds of the rich avian region adjacent. Prin. Silloway.

Botany:

(a) Laboratory and field course; study of type forms. The course will consist of collecting trips in the field where common species of the different orders are found, classification of the more common species, study of structure, with methods of preservation, both dry and in liquid, for immediate and permanent use. Prin. Silloway.

(b) Forest Ecology: This course will consider the problems connected with forest botany. The work will be mainly in the field. Limited areas will be examined carefully to find out, if possible, the order of succession of different forests and to determine the relations of other plant societies to forest societies. More hasty surveys of larger areas will be made to verify and, if need be, to change the conclusions.

The following lectures, and possibly others, will be given in connection with the field work.

Factors controlling distribution of plants.

The tension zone between the prairie and the forests.

The genetic relations of plant societies in an alpine region: Mr. Whitford.

(c) Laboratory course, work to be arranged.

\section{Photography:}

No regular course will be given in this subject, but every aid which the station can give will be given those who wish to become proficient in this art. Stud unts in photography must supply their own plates or films and paper. There is a dark room at the laboratory and the scenery in the vicinity gives ample scope for a series of negatives either in landscape or of scientific subjects.

\section{Nature Study:}

For those who may desire it a course of study and practical work will be outlined which will afford both a fund of information on which to draw during school work and at the same time secure a collection of material to be used in illustration. The scope of the work will include zoology, botany, geology, and physiography of the region. Prin. Ricker will direct the work.

\section{METHODS OF INSTRUCTION.}

The work will consist very largely of field collecting and observation, study of relation to environment supplemented by laboratory dissections and microscopic examination. The general courses will enable teachers to familiarize themselves with methods of field work, and give a store of information from which to draw in nature study subjects. The general courses also give opportunity to students and others to pursue lines of study with better facilities for out door work, with fresh material, than is generally to be had in regular university work. For this work students may receive credit on regular university and preparatory courses which are an equivalent.

Five days in the week will be devoted to laboratory and field work. The sixth will be given up to excursions. Hor the past three years it has been the custom at the Station to have campfire discussions. These have proven helpful and valuable, and will be continued. 
The work of the Station is materially advanced by co-operation with the University of Chicago. Mr. H. N. Whitford will arrive at the Station about August first with a class, and will prosecute botanical study in the region. Students from the state may join his classes and receive all benefits therefrom.

\section{CREDIT FOR WORK.}

Students attending the station may have credit on the University of Montana books for such work as may be done, either as college or preparatory, whichever may be proper. Students in work of Mr. Whitford may have credit on the University of Chicago books on payment of tuition fee.

\section{LECTURES.}

During the session the lectures following will be given at the laboratory. They will be given daily, at least one each day. The list will probably be increased, and may be slightly modified. They are free to all students attending, and to any others who may choose to hear them.

Natural Counterfeits, Mimicry and Protective Resemblance, illustrated by water color drawings; The Life History of a Dragonfly, illustrated by specimens; The Life History of an Oak, illustrated by water color drawings; The Anatomy and Distribution of the Hydra, illustrated by specimens; The Entomostraca, their Numbers, Distribution and Utility; Some Animal Allies of Common Plants, stories of adaptation for cross fertilization, illustrated by water color drawings; Recognition of Birds in the Field; Types of Nests of Birds, with special reference to the region; Physiography of the Region Adjacent to the Station; Daphnia Pond, a Study of Environment; How to Study a Bird; Bird Songs and their Significance; Migration of Birds, causes, direction, distance, etc.; Natural History in the Graded Schools; Insects as Friends and as Foes, with practical illustrations; The Game Birds of Montana, recognition, number, habits, etc., Photography, Its Use in the Class Room and in Science; Factors controlling the Distribution of Plants; The Tension Zone between the Prairie and Forests; The Genetic Relations of Plant Societies in an Alpine Region.

\section{EXCURSIONS.}

The following excursions will be taken during the session of the Station work, unless the weather is unfavorable.

1. A trip to Swan Lake, through the forests, with stop over night at the lake. This is a beautiful lake in the mountains, of great interest biologically and geologically.

2. A trip to Rost Lake, at the base of the Kootenay Mountains. This is a lake almost filled up, a fine collecting field. It is in an admirable location for camps.

3. An ascent of MacDougal Peak via an Indian trail, to an altitude of 7,650 feet. This will afford opportunity for alpine collecting, and will present some of the most sublime scenery in the world.

4. A trip around Flathead Lake, making study of its banks, bays, and swamps.

These trips will be under the personal supervision of Director of the Station. Those taking the trips must bear a proportionate share of the expense necessary. Such will prove of great value and interest biologically aside from the pleasures they bring.

\section{RECREATION.}

Many will wish to combine an outing with study. Fishing near the laboratory is excellent. There are many boats besides those of the Station, and rowing may be indulged in. The field is excellent for photography. Bathing in the lake is always a treat and the beach is fine. The region has an abundance of fruit of all kinds. The hills and forests afford quiet retreats for study or for strolls. Few places have more natural attractions. At the proper season hunting is good. Deer have been seen a few rods from the laboratory. Grouse and pheasants abound in the hills. In season duck shooting is fine. Most of the country affords good wheeling for bicycles.

\section{FEES AND EXPENSES.}

There are no tuition fees. Students attending will be charged for material consumed, for breakage, for a share of the expense for excursions, and like necessary expense. Necessary books, chemicals, micro- 
scopes, and glassware will be supplied free. The intention is to give the best facilities possible, so as to make it worth while for students to attend.

Good board may be had convenient to the laboratory for $\$ 5.00$ per week, with room extra. It is customary for most of those attending to sleep in tents, on the Station grounds, taking meals only. For those who wish to tent and cook in regular camp style there will be every opportunity given for comfort, the region affording a bountiful food supply of everything necessary, but those attending will be expected to supply their own tents and bedding.

\section{AFTER THE SESSION.}

Mr. Whitford's students will spend two weeks at the Station, after which two weeks or more will be devoted to study of mountain flora and environment, under his guidance and direction.

The Director and some of the staff will continue investigations on Flathead Lake and Echo Lake for three or four weeks after the regular work of the Station closes, using the laboratory as headquarters.

The laboratory building and grounds may be used by those who wish to carry on investigative work at all times during the season. It makes an excellent place for headquarters. Correspondence in regard to above work is invited.

\section{DATE OF OPENING.}

The course of instruction will open Monday, July 14, and continue five weeks. It will be most satisfactory to enter at the beginning, but from the flature of the work students may enter at any time.

Applications should be made as early as possible, as the accommodations are limited, and the material taken from the University will of necessity be only enough to supply those in attendance.

A collecting trip will be taken after the Station closes. It will be possible for a very small number to accompany this expedition on payment of a share of the expense. For details see "After the Session."

\section{HOW TO REACH THE STATION.}

Students via Northern Pacific will get off at Selish. Stage triweekly runs to Flathead Lake, ( 35 miles), connecting with steamer Klondike, which runs across the lake. Stage fare, one way, \$3.00, round trip, $\$ 5.00$, trunks extra. Boat fare across the lake, one way, $\$ 3.00$, round trip, $\$ 5.00$. Stage leaves Selish on Mondays, Wednesdays and Fridays, connecting with the steamer, returning the same day.

Students via Great Northern will get off at Kalispell, connecting by stage with the steamer Klondike at Demersville, a short distance from Kalispell.

\section{OPPORTUNITIES FOR INVESTIGATION.}

Any one wishing to engage in investigation of biological problems pertaining to the life of the locality, before or after the regular work, will be given the freedom of the building, boats and apparatus, and will be offered every facility possible. In such cases no fees will be charged, except for special material or reagents which may be needed.

\section{WHO HAVE ATTENDED.}

During the three years the Station has been opened the attendance has been from many states other than Montana, eight states having had representatives, representing colleges, academies, private schools, high schools, principals of public schools, students of different educational institutions, teachers of graded and country schools, and people in professional and private life. As a place where maximum work may be accomplished with minimum loss of time in a new field, under competent guidance in finding material and localities, the Station will appeal to any one interested in the work it is doing.

For further information relative to courses, routes, expenses, necessary outfit, etc., address,

\section{MORTON J. ELROD,}

Missoula, Montana.

For any information concerning the University of Montana, its departments, courses or study, etc., address, 
Bul. Univ. of Mont., Biol. Series No. 1.

Plate I.

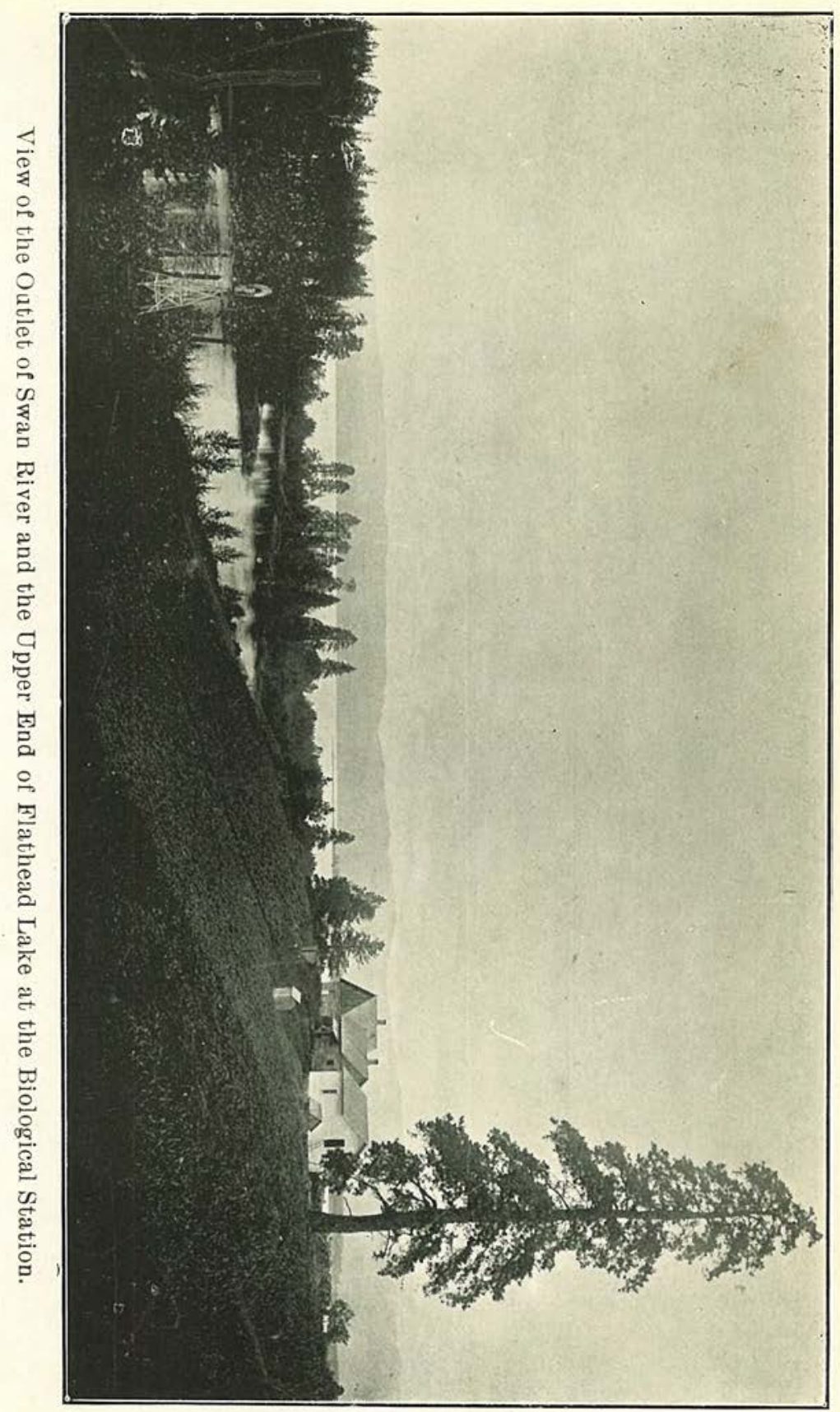



Bul. Univ. of Mont., Biol. Series No. 1.

Plate'II.

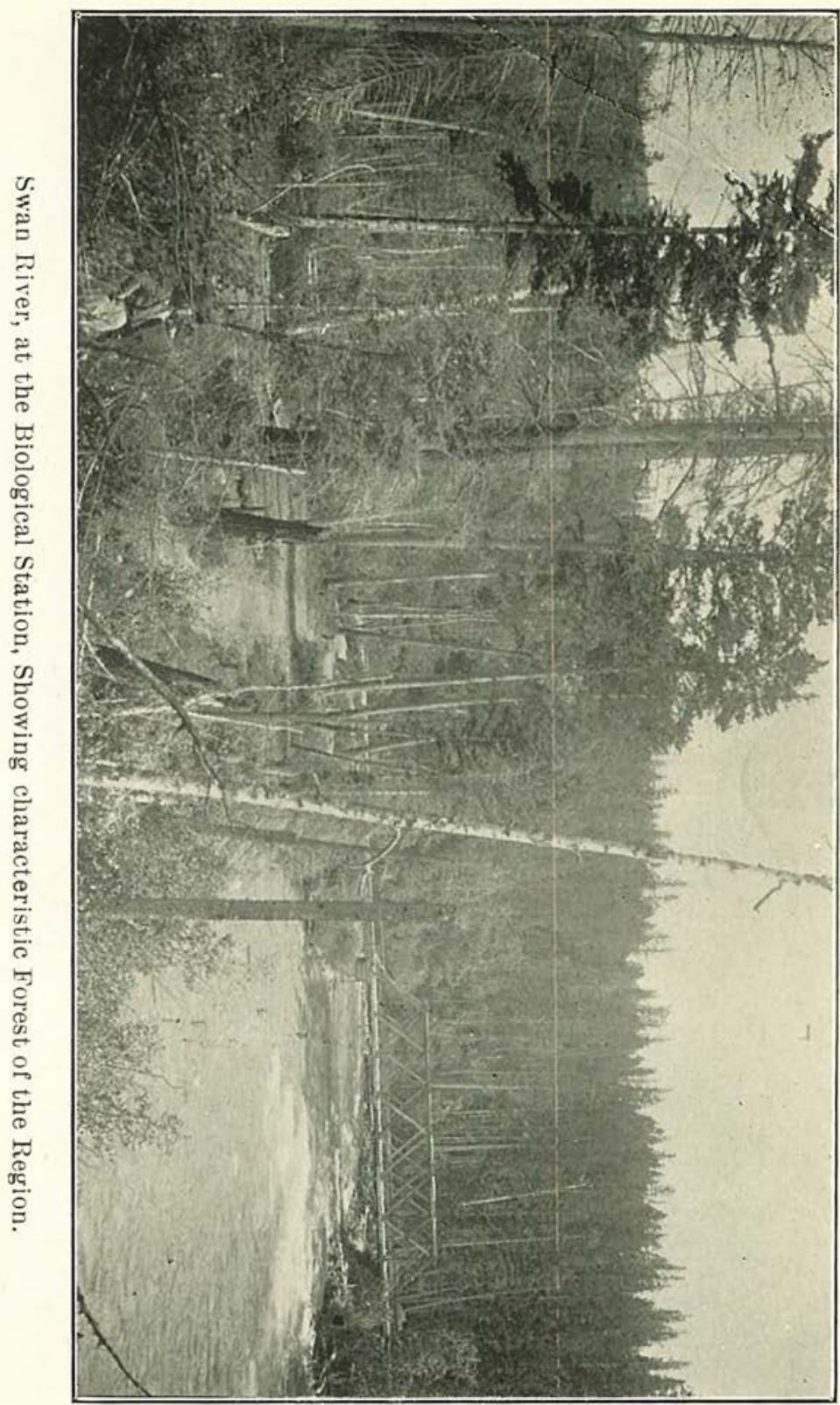




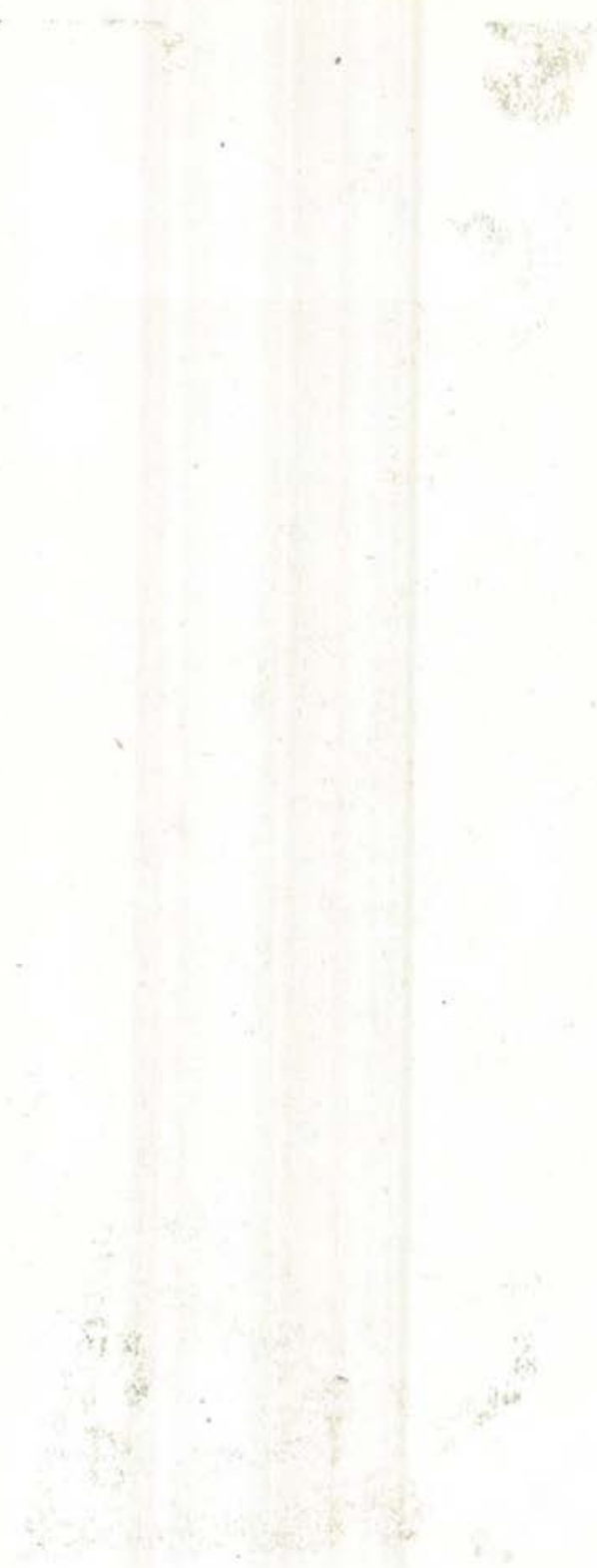


Bul. Univ. of Mont., Biol. Series No. 1. Plate III.

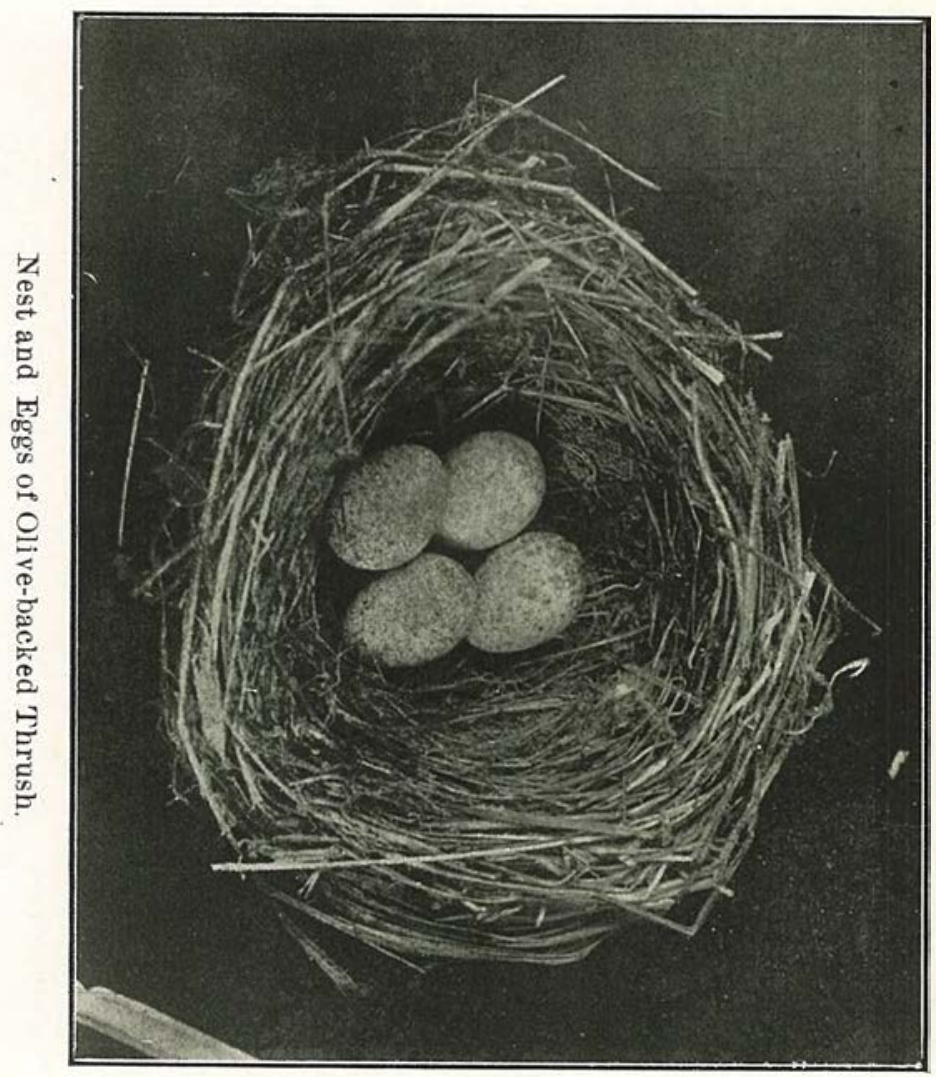





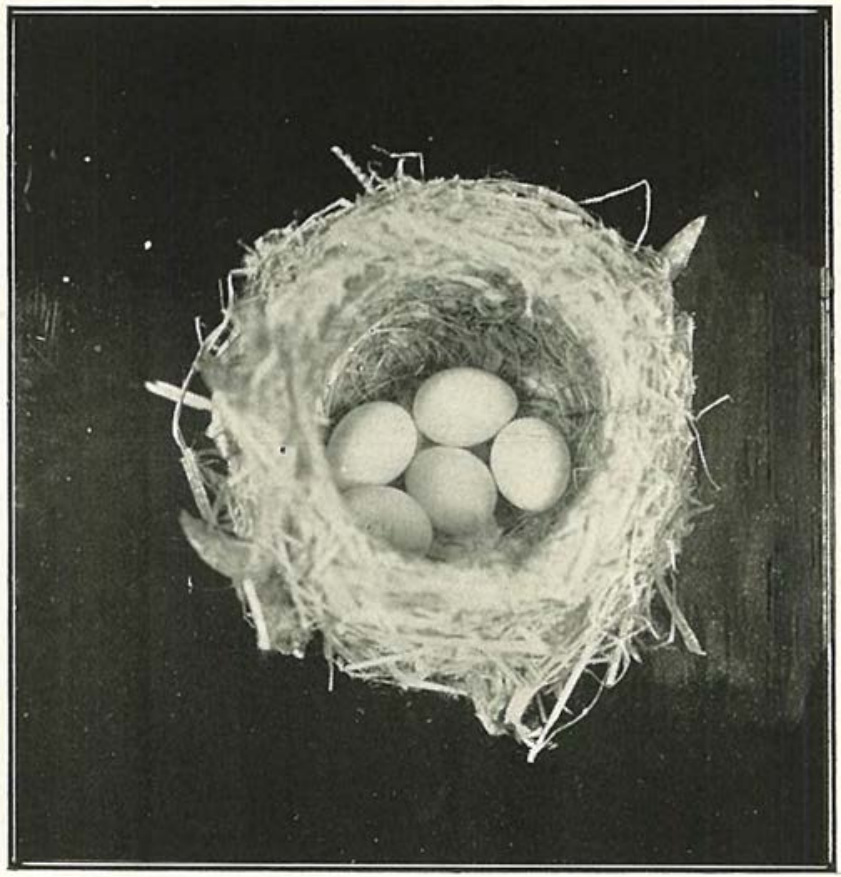

Fig. 1. Nest and Eggs of Wright's Flycatcher, Empidonax wrightii Baird. Compare-with Plate VII and XVI.

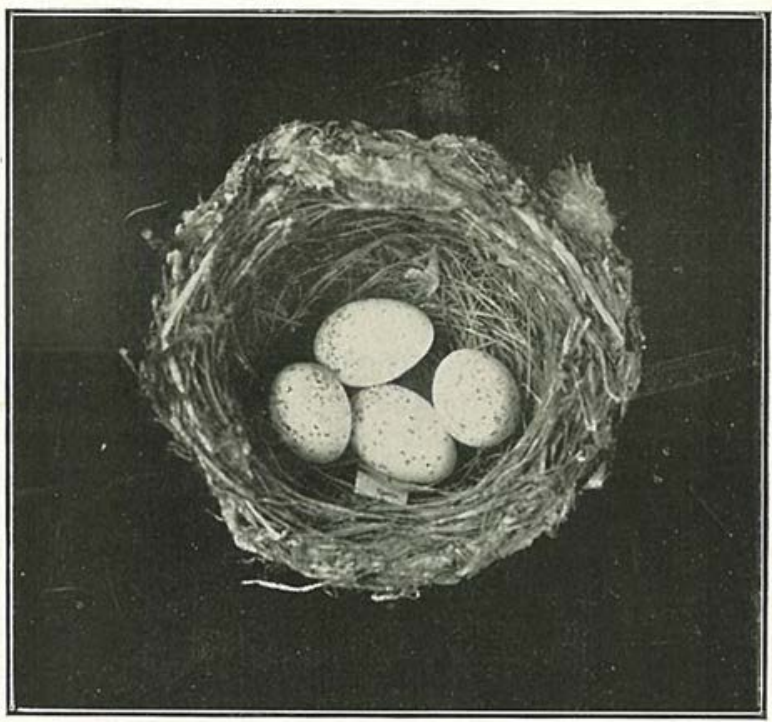

Fig. 2. Nest and Eggs of American Redstart Setophaga ruticilla L. 



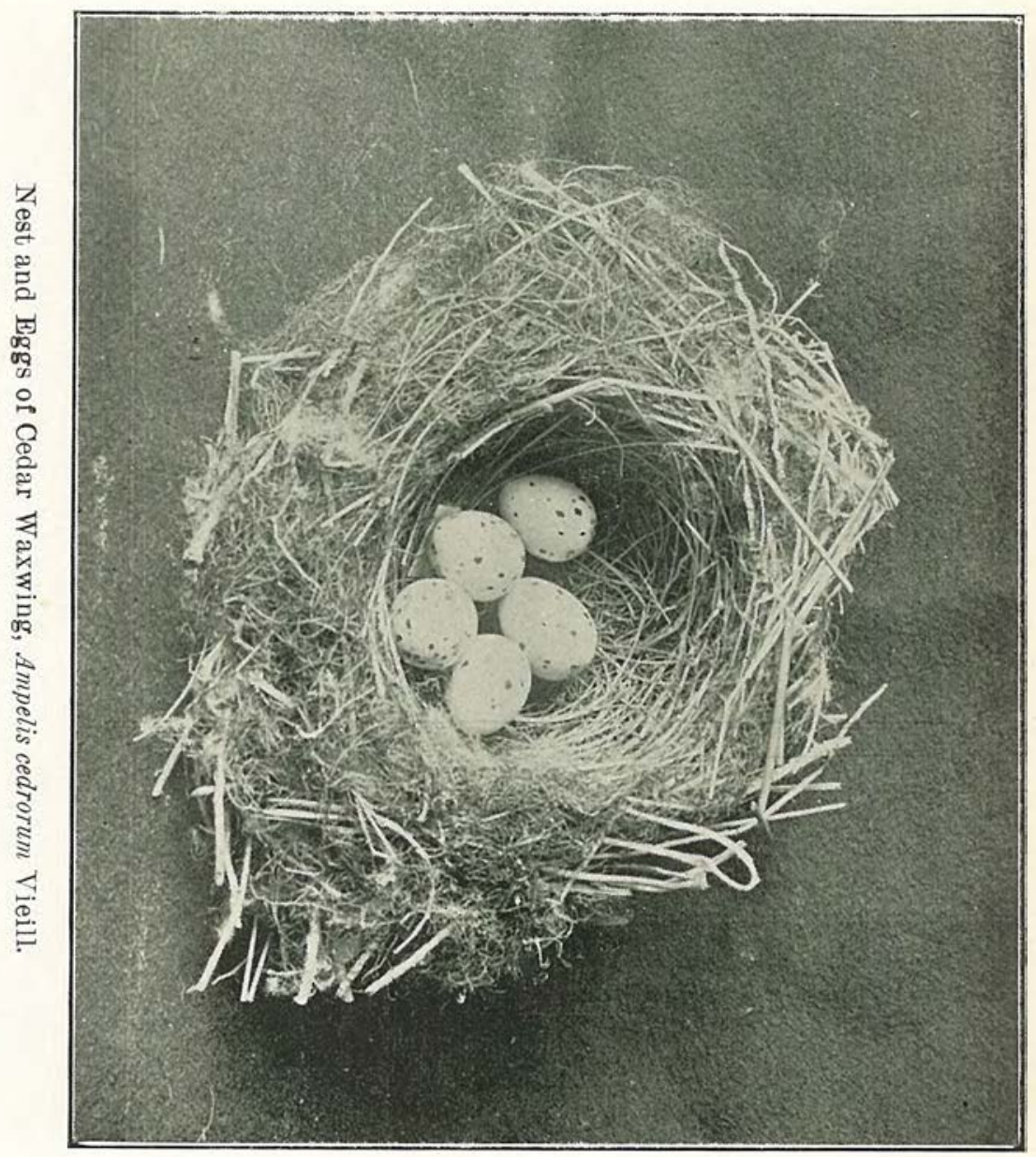



Bul. Univ. of Mont., Biol. Series No. 1.

Plate VI.

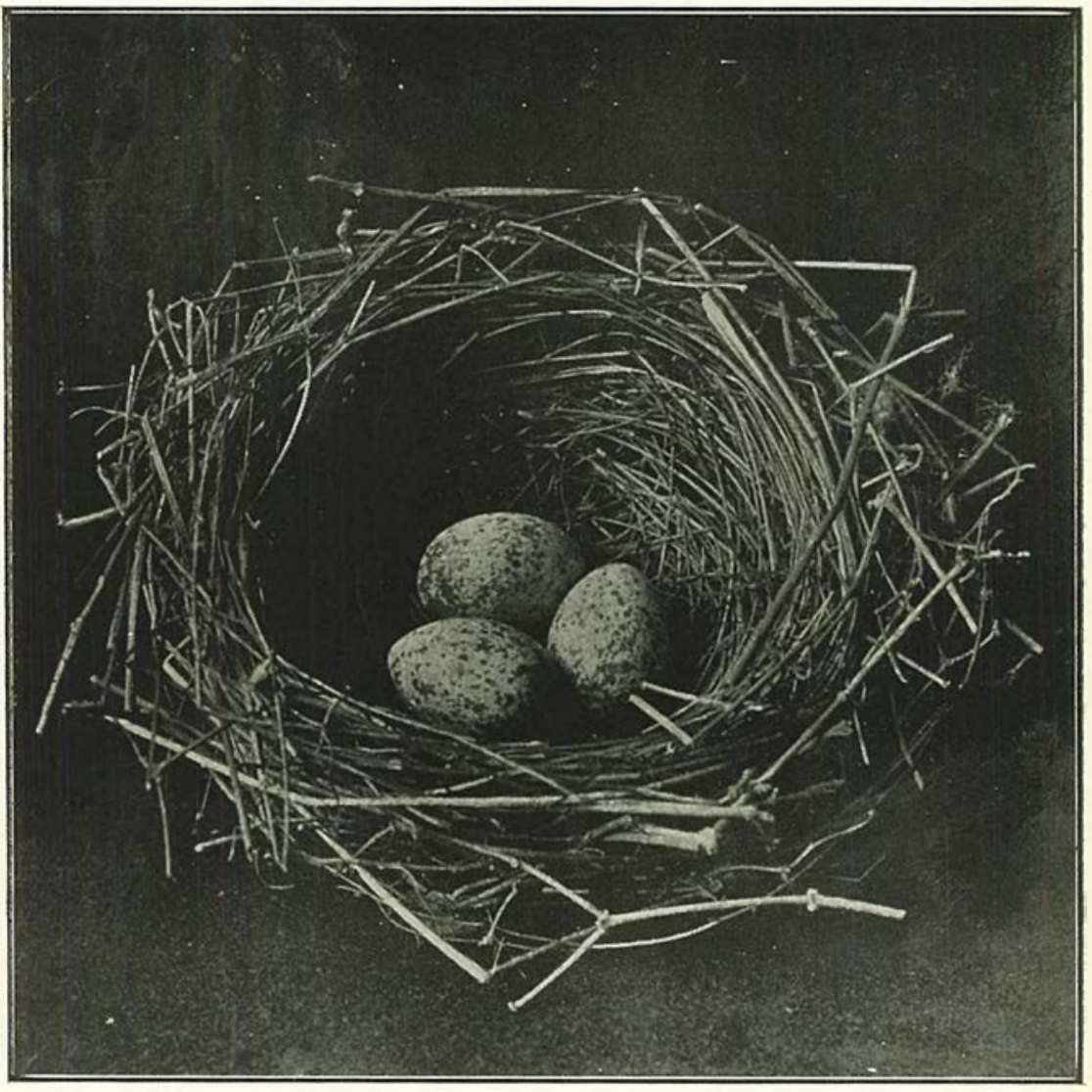

Nest and Egg of Black-headed Grosbeak, Habia melanocephala Swains. 



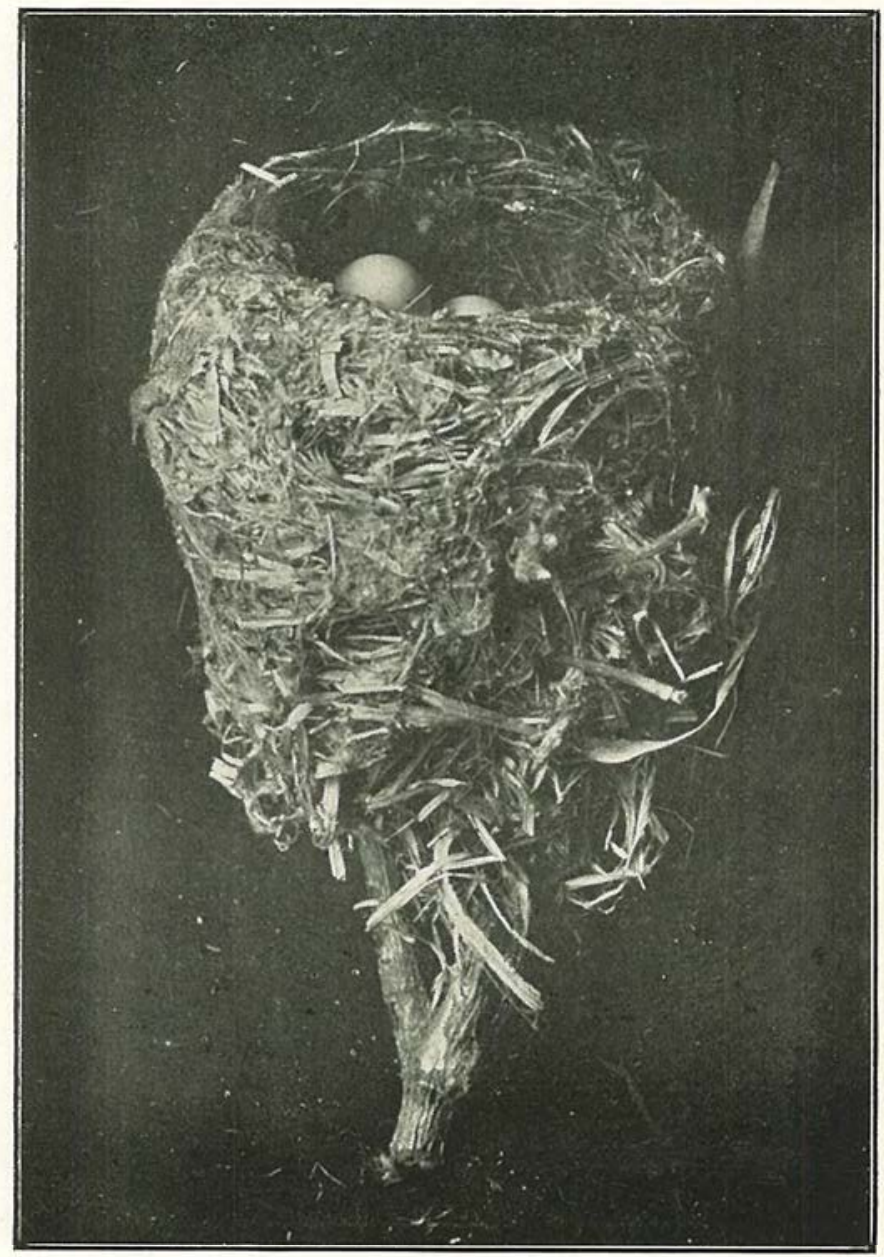

Nest and Eggs of Wright's Flycatcher, Empidonax wrightii. Compare with Plate IV, Fig. 1, and Plate XVI. 


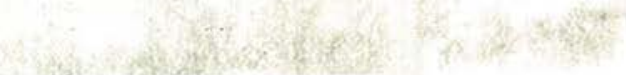




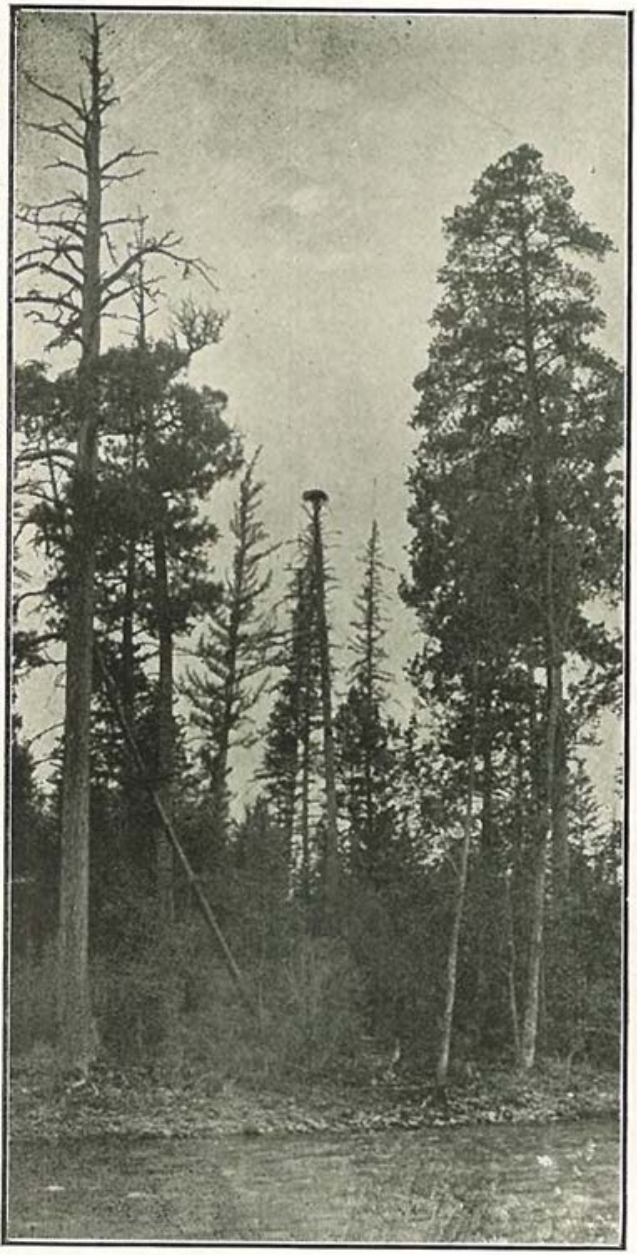

FiG. 1.

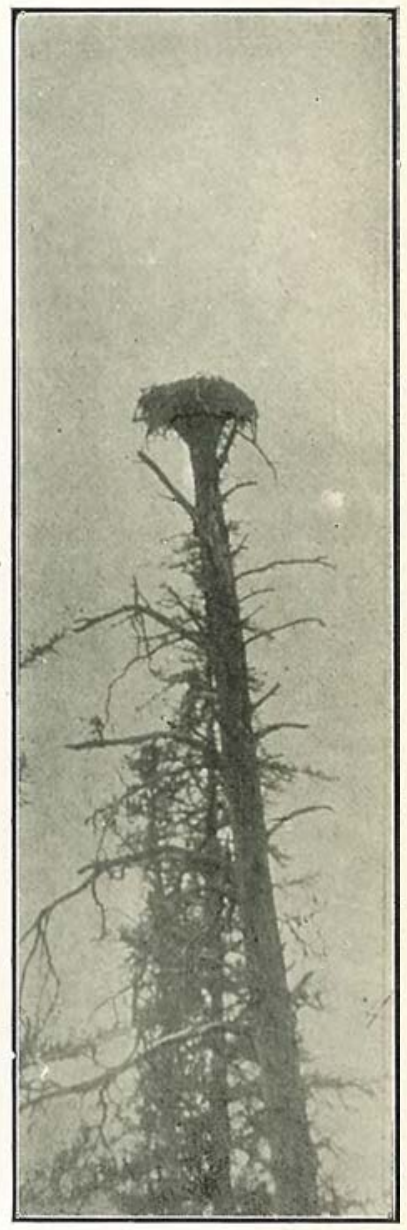

FIG. 2,

Fig. 1. Osprey Nest on the Bank of Swan River, opposite the Biological Station. Taken with wide angled Lens, orthochromatic Plate.

Fig. 2. Same Nest as Fig. 1, taken from the same Place and at the same Time, with telephoto Lens, magnification eight Diameters. 
.... क w

25 
Bul. Univ. of Mont., Biol. Series No. 1.

Plate IX.

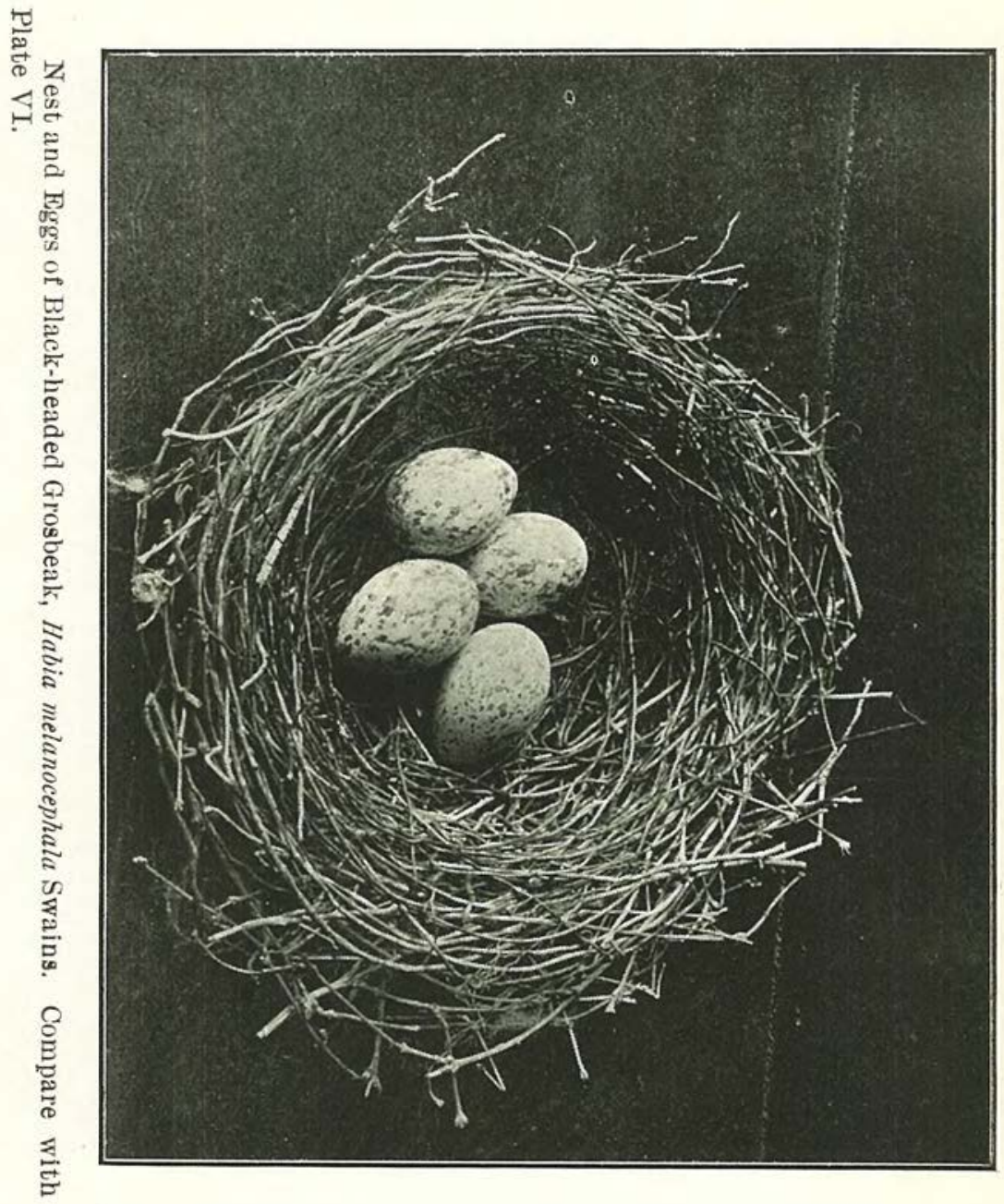



Bul. Univ. of Mont., Biol. Series No. 1.

Plate X.

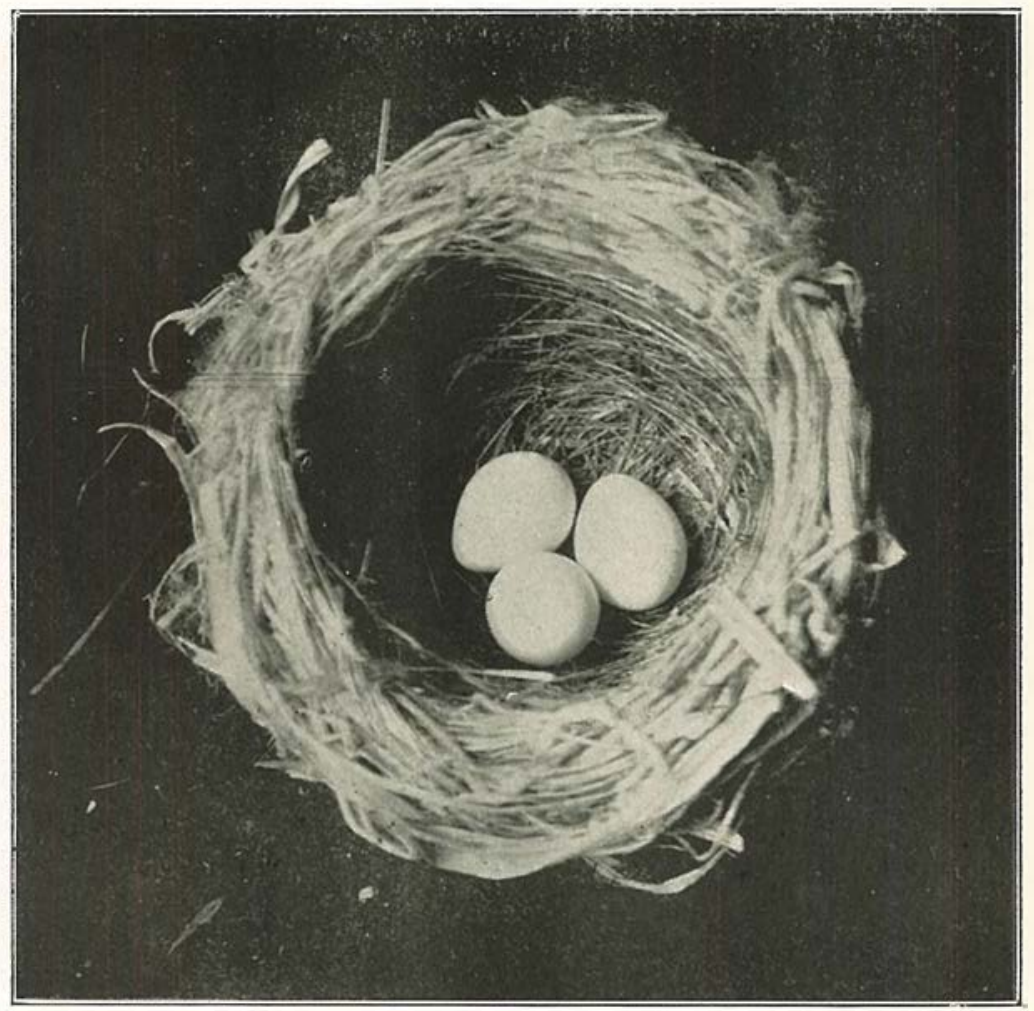

Nest and Eggs of Lazuli Bunting, Passerina amoena Say. 
Bul. Univ. of Mont., Biol. Series No. 1.

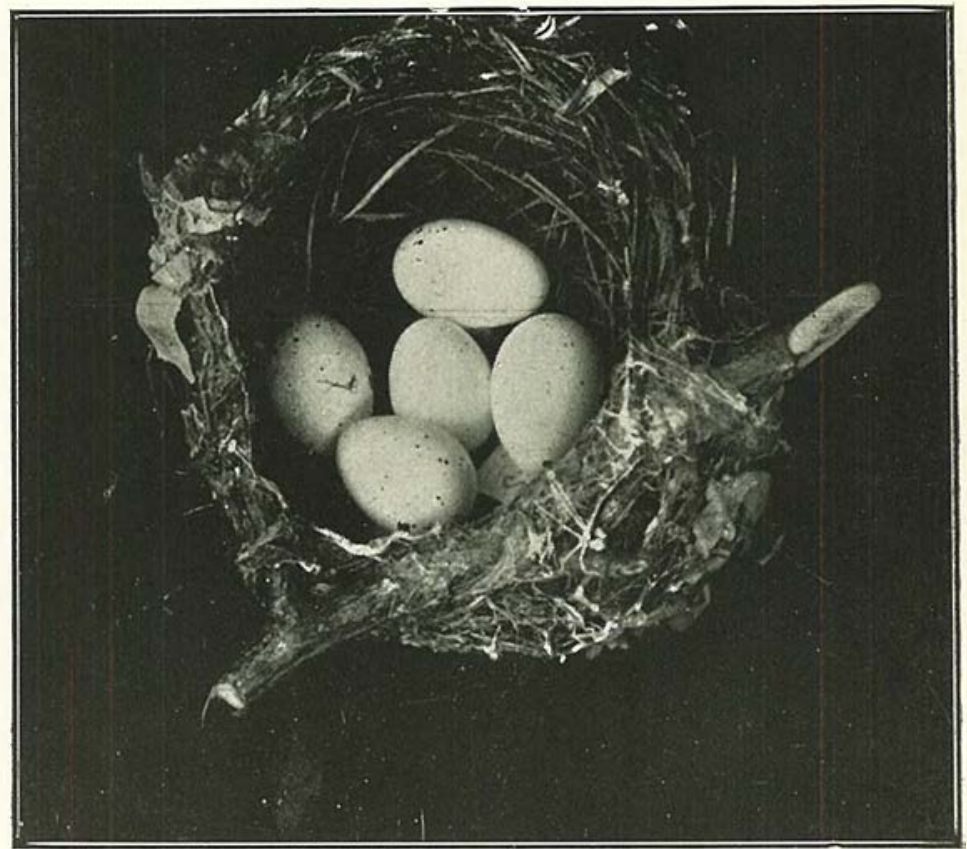

Nest and full Complement of Eggs of Red-eved Vireo, Vireo olivaceus L. From Photograph with Orthochromatic Plate and Ray Filter. 

Bul. Univ. of Mont., Biol. Series No. 1.

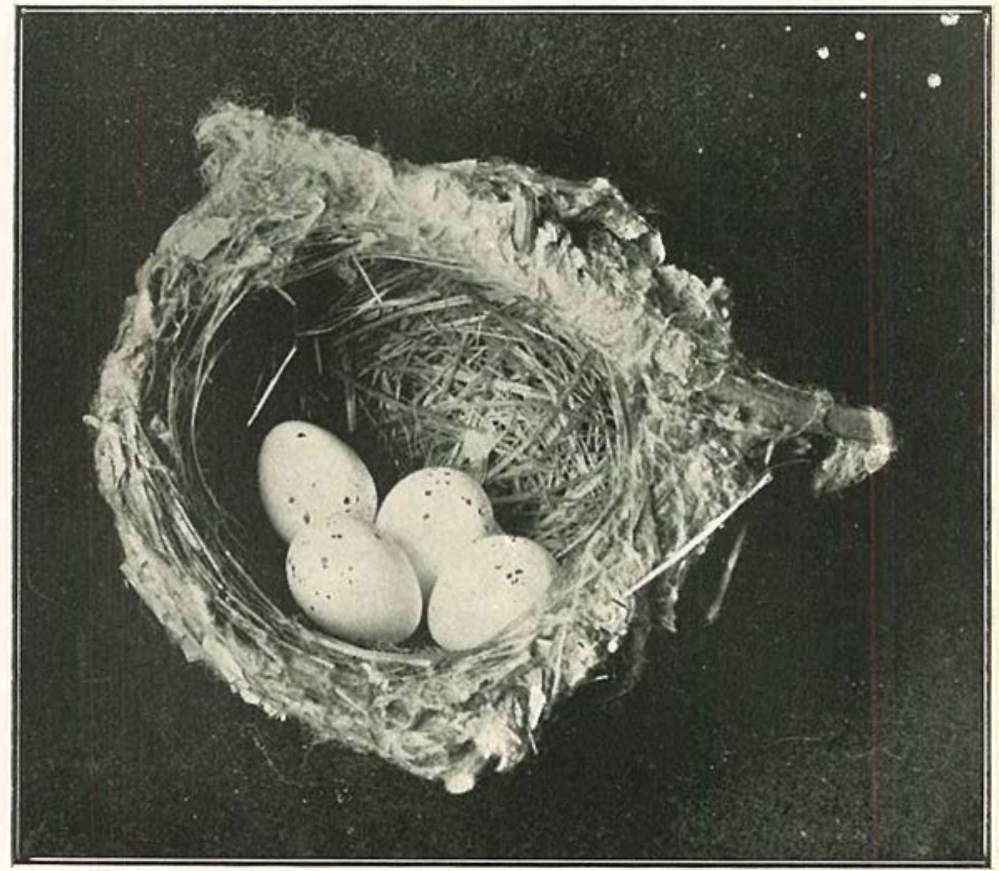

Nest and Eggs of Warbling Vireo, Vireo gilvus Vieill. 



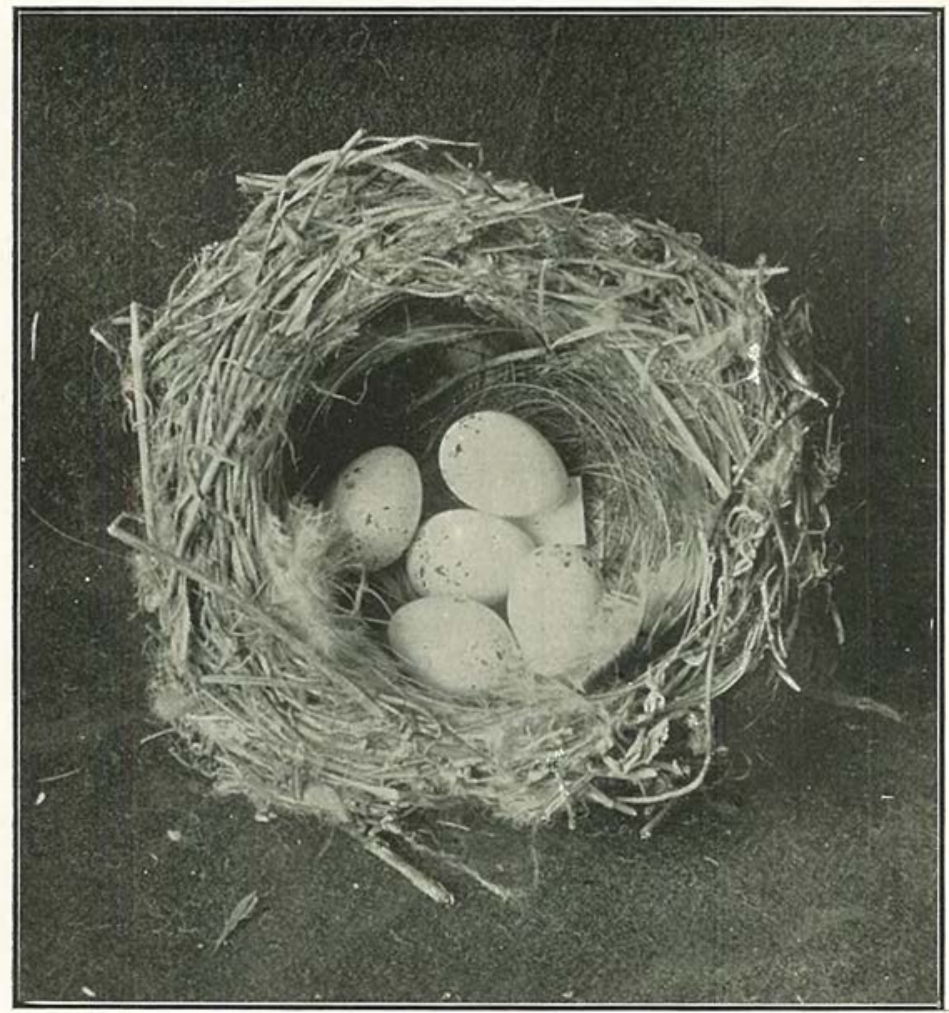

Nest and Eggs of Andubon's Warbler, Dendroica auduboni Towns. From Photograph made at the University of Montana Biological Station, with Orthochromatic Plate and Ray Filter. 



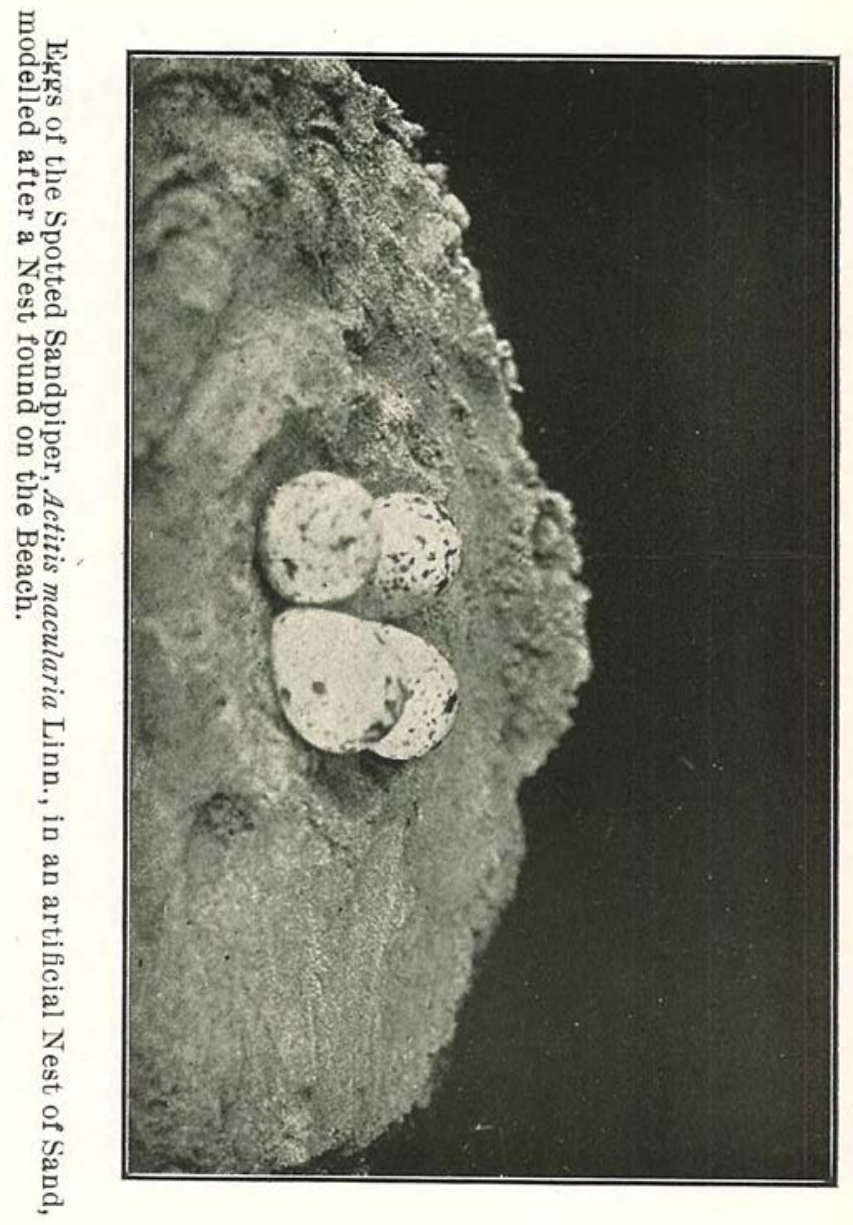



Bul. Univ. of Mont., Biol. Series No. 1.

Plate XV.

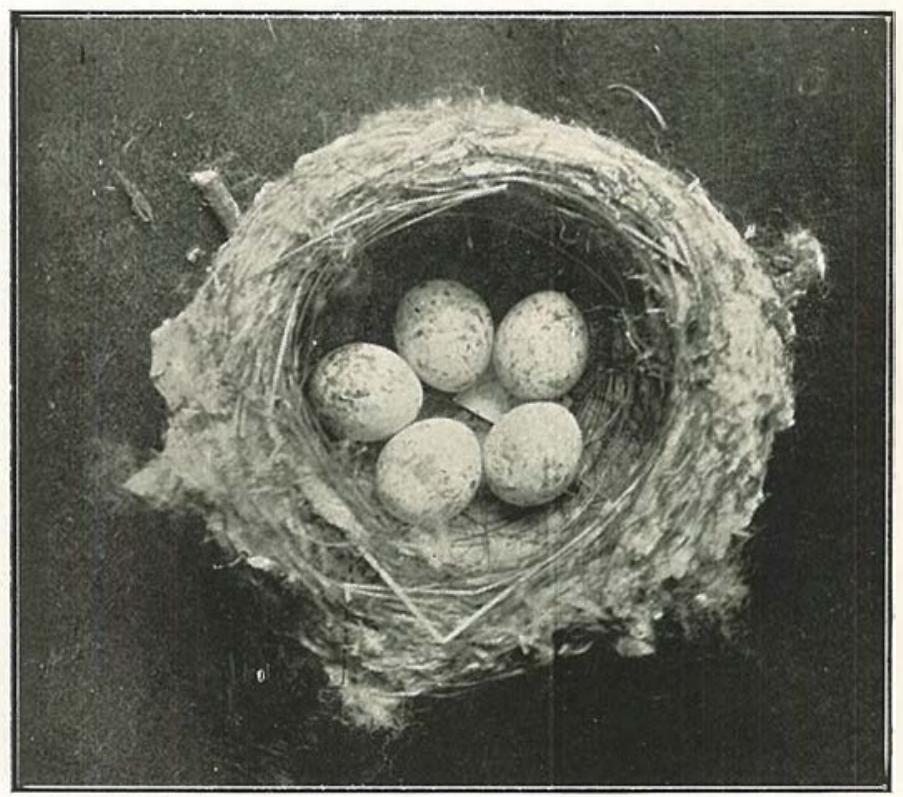

Nest and Eggs of Yellow Warbler, 1)endroica aestiva Gmel. From Photograph made at the University of Montana Biological Station. 



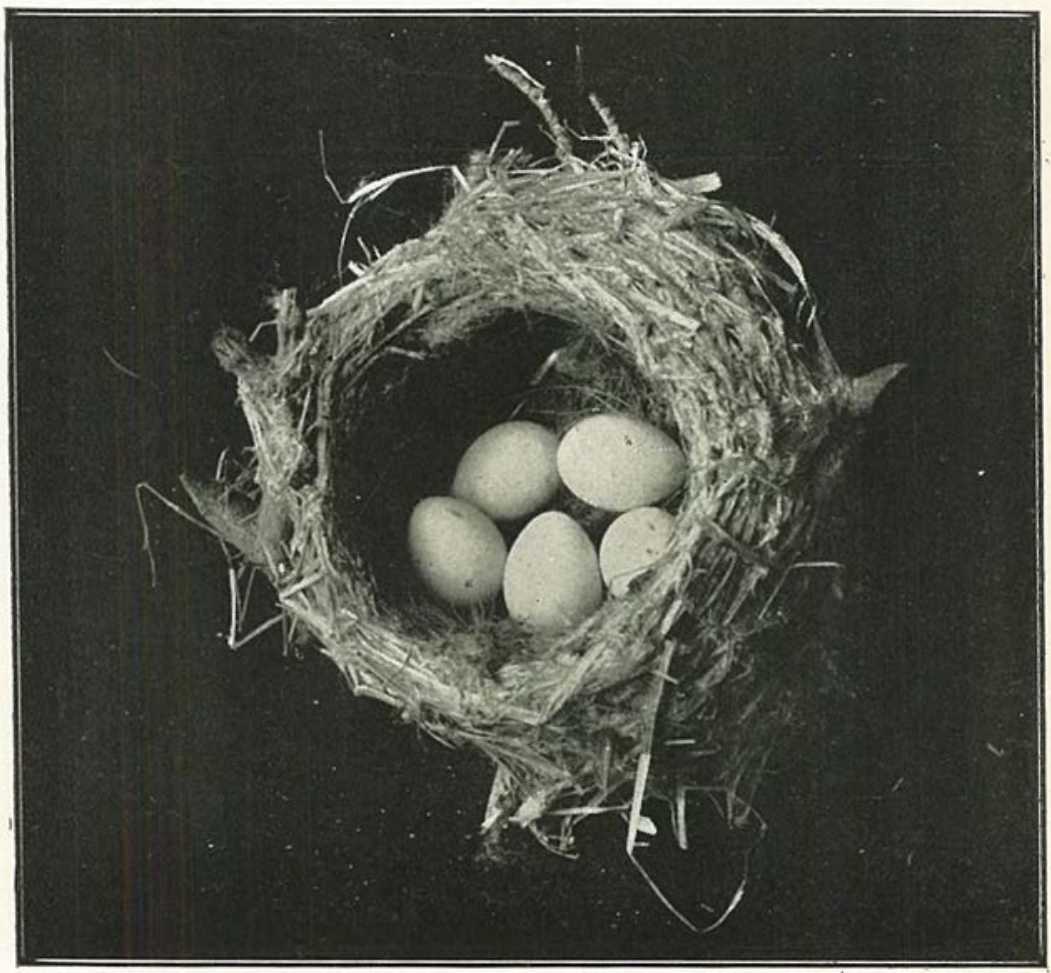

Wright's Flycatcher, kmpidonax wrightii. Top View, looking into the Nest. Compare with Plate IV, Fig. 1, and Plate VII. 